1 Recent Advances in Cleaner Hydrogen Productions via Thermo2 catalytic Decomposition of Methane: Admixture with Hydrocarbon

Anuar Faua'ad Syed Muhammad ${ }^{1}$, Ali Awad ${ }^{2}$, R. Saidur ${ }^{3,4}$, Nurliyana Masiran $^{2}$, Md. Abdus Salam $^{5}$, Bawadi Abdullah*2,6

${ }^{1}$ Bioprocess and Polymer Engineering Department, Faculty of Chemical and Energy Engineering, Universiti Teknologi Malaysia, 81310 UTM Skudai, Johor, Malaysia

${ }^{2}$ Chemical Engineering Department, Universiti Teknologi PETRONAS, 32610 Seri Iskandar, Malaysia

${ }^{3}$ Research Centre for Nano-Materials and Energy Technology (RCNMET), School of Science and Technology, Sunway University, Jalan University, 47500 Bandar Sunway, Selangor Malaysia

${ }^{4}$ Department of Engineering, Lancaster University, Lancaster, LA1 4YW, UK

${ }^{5}$ Hydrogen Energy Technology Laboratory, BCSIR Laboratories, Chittagong, Bangladesh

${ }^{6} \mathrm{CO}_{2}$ Utilization Group, Institute of Contaminant Management for Oil and Gas, Universiti Teknologi PETRONAS, 32610 Seri Iskandar, Malaysia

*Corresponding author: bawadi_abdullah@utp.edu.my, bawadi73@gmail.com,+6018-2310773

\title{
Abstract
}

A continuous increase in the greenhouse gases concentration due to combustion of fossil fuels for energy generation in the recent decades has sparked interest among the researchers to find a quick solution to this problem. One viable solution is to use hydrogen as a clean and effective source of energy. In this paper, an extensive review has been made on the effectiveness of metallic catalyst in hydrocarbon reforming for $\mathrm{CO}_{\mathrm{X}}$ free hydrogen production via different techniques. Among all metallic catalyst, Ni-based materials impregnated with various transition metals as promoters exhibited prolonged stability, high methane conversions, better thermal resistance and improved coke resistance. This review also assesses the effect of reaction temperature, gas hour space velocity and metal loading on the sustainability of thermocatalytic decomposition TCD of methane. The practice of co-feeding of methane with other hydrocarbons specifically ethylene, propylene, hydrogen sulphide, and ethanol are classified in this paper with the detailed overview of TCD reaction kinetics over an empirical model based on power law that has been presented. In 
addition, it is also expected that the outlook of TCD of methane for green hydrogen production

34 will provide researchers with an excellent platform to the future direction of the process over $\mathrm{Ni}$ -

35 based catalysts.

36

37

Key Words: Hydrogen production, Methane Conversion, Metallic Catalyst, Process Parameters, Co-Feeding, Reaction Kinetics

\section{Table of Contents}

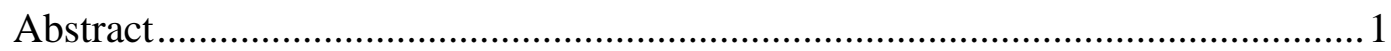

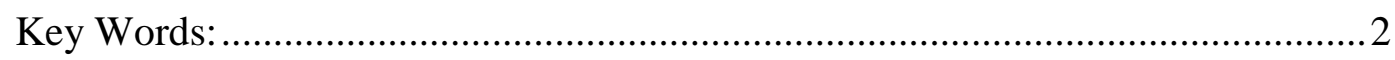

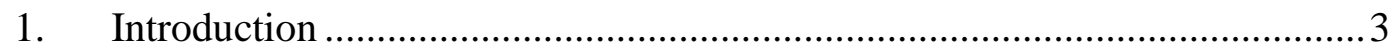

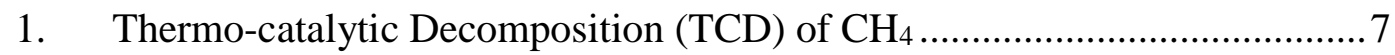

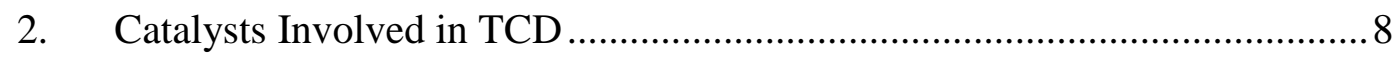

2.1. Mono Metallic Catalyst ........................................................................... 8

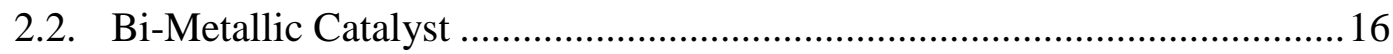

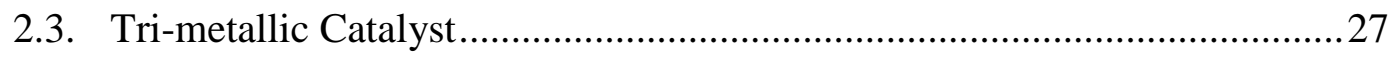

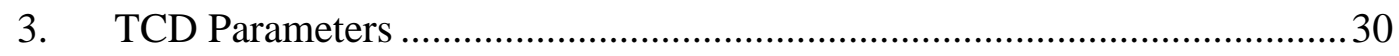

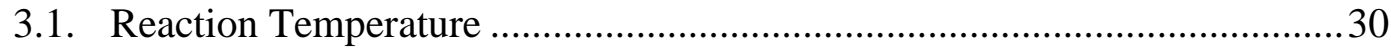

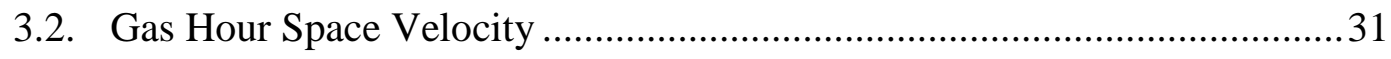

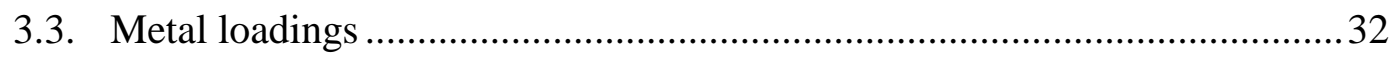

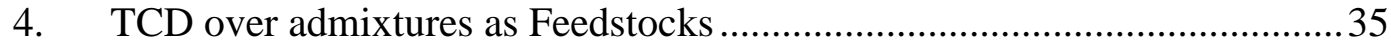

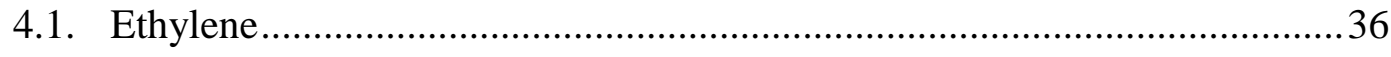

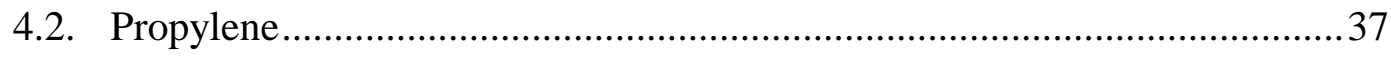

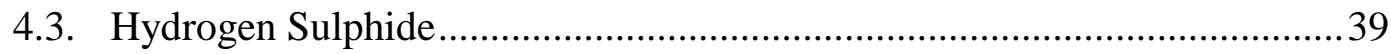

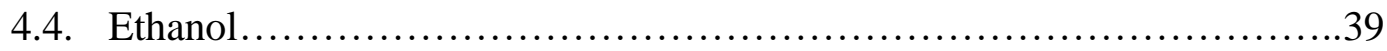

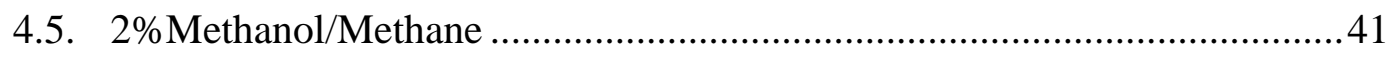

5. Kinetics and reaction mechanism of TCD …................................... 41

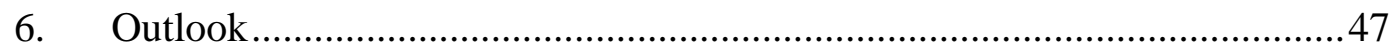

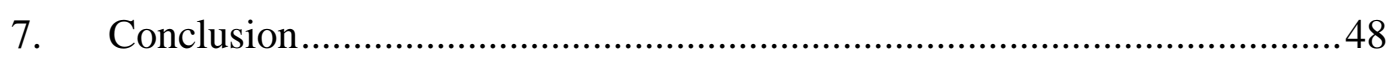

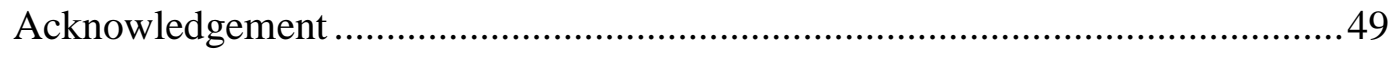




\section{Introduction}

64 The combustion of fossil fuels such as coal, oil, gasoline and natural gas satisfy the energy 65 demands of industry and domestic users. However, they will run out momentarily due to the

66

67 rapidly increasing demands [1]. Furthermore, the global warming, greenhouse effect, hole in ozone layer, acid rains and environmental pollution are the drastic effects caused by the fossil fuel combustion [2]. USA, Japan, and Germany are leading the race of $\mathrm{CO}_{2}$ emissions as they have well stabilized industrial sectors [3]. The concentration of $\mathrm{CO}_{2}$ in the atmosphere has increased drastically from $396 \mathrm{ppm}$ to $400 \mathrm{ppm}$ in recent few years. Moreover, it is estimated that these emissions will increase from 30 billion metric tons to 43 billion metric tons in 2035 [4]. The average temperature of the earth according to climate forecasts may increase from 274 to $279 \mathrm{~K}$ if the increasing greenhouse gas emissions are not critically considered. [5]. Extensive solutions have been reported by the researchers to reduce the hazardous effects of increasing concentration of $\mathrm{CO}_{2}$ in the atmosphere by establishing various methods of $\mathrm{CO}_{2}$ capture such as absorption, cryogenic and membrane processes [6]. Another method has been reported by using photocatalytic reactors [7] to convert excessive $\mathrm{CO}_{2}$ into useful products such as $\mathrm{CH}_{4}$ and $\mathrm{CH}_{3} \mathrm{OH}$. The invention of few high energy efficient green fuels that reduce the emissions of poisonous gases during combustion is also quoted as an active solution to control greenhouse effect. The search for alternative high energy efficient green fuels has been broadly investigated by many researchers in the past. $\mathrm{H}_{2}$ has been termed as one of the greenest and lightest fuel that can fill in the energy gap which will be created in the upcoming future. Because of hydrogen's abundance, lightweight, low mass density, high calorific value and non-polluting nature make it a unique source of energy. 
84 Moreover, it has been published that $\mathrm{H}_{2}$ has the highest heat of combustion, i.e. $142 \mathrm{~kJ} \mathrm{~g}^{-1}$ as

85 compared to petroleum and wood that exhibit 43-35 and $18 \mathrm{~kJ} \mathrm{~g}^{-1}$ respectively [8].

86

87

88

89

90

91

92

93

94

95

96

97

98

99

100

101

102

103

104

105

106

The annual $\mathrm{H}_{2}$ consumption in 2006 was around 50 million tons including industrial and domestic usage. Around $50 \%$ of this consumption was attributed to $\mathrm{NH}_{3}$ industries, $37 \%$ in petroleum refineries, $7 \%$ in $\mathrm{CH}_{3} \mathrm{OH}$ production and $6 \%$ in other fields. It has been reported that the $\mathrm{H}_{2}$ produced in existing date has to be multiplied 100 times approximately to meet the world's demand for fossil fuels presently [9]. It is believed that $\mathrm{H}_{2}$ will play a vital role in fulfilling the extensive energy requirements. However, $\mathrm{H}_{2}$ cannot be found freely in the atmosphere instead of in the form of bonds with other molecules that indicate its reactivity. Therefore, it must be extracted from other primary energy sources like coal, natural gas, water or other heavy hydrocarbons [10]. Global statistics illustrate that the significant amount of $\mathrm{H}_{2}$ is being produced by the reforming of natural gas, i.e. $48 \%$, electrolysis of water gives $30 \%, 18 \%$ from burning petroleum products and $4 \%$ by coal. The significant contribution to the production of $\mathrm{H}_{2}$ is from natural gas since there are vast reservoirs of $\mathrm{CH}_{4}$ in deep seabed especially in industrialized countries like United States [11]. Natural gas has been named as the primary energy contributor since early 20's in Malaysia. In 2008 alone, approximately over 2.5 trillion $\mathrm{m}^{3}$ of the natural gas reserve were found in Malaysia specifically in Sarawak (East Malaysia). Moreover, the natural gas reserves in Malaysia are the largest in South East Asia and $12^{\text {th }}$ largest around the globe [12].

There are various methods for the $\mathrm{H}_{2}$ production such as; steam reforming (SRM), partial oxidation (POM), dry reforming (DRM) and thermocatalytic decomposition of $\mathrm{CH}_{4}$ (TCD) [13-15]. Among these methods, POM, SRM, and DRM are considered as indirect methods of $\mathrm{H}_{2}$ production. In these methods, $\mathrm{CH}_{4}$ is treated with $\mathrm{O}_{2}, \mathrm{H}_{2} \mathrm{O}$ and $\mathrm{CO}_{2}$ under given a set of reaction conditions to produce synthesis gas as a mixture of $\mathrm{H}_{2}$ and $\mathrm{CO}$ [16]. However, there is a common shortcoming 
107 in all these three processes in the form of emissions of greenhouse gases $\mathrm{CO}_{2}$ and $\mathrm{CO}$. These gases 108 not only play a major role in global warming but also are very harmful when their mixed feedstock 109 with $\mathrm{H}_{2}$ is used in low-temperature fuel cells like proton exchange membrane fuel cells (PEMFC) $110 \quad[17]$.

111 Keeping in view the greenhouse gas emissions and its economic issues, the interest of researchers 112 moved towards exploring a more optimum and green process for $\mathrm{H}_{2}$ production. Thermocatalytic 113 decomposition (TCD) is a practical approach to decompose $\mathrm{CH}_{4}$ into $\mathrm{H}_{2}$ and elemental carbon 114 thermally. This method is considered novel and eco-friendly as there is no emission of greenhouse 115 gases during the reaction [18].

116 Various review papers have been published in the past decades on this topic for example Jose et 117 al. [19], Abbas et al. [9], Ashik et al. [20], Srilatha et al. [21], Sikander et al. [15] and Yongsan et 118 al. [8-10]. Nonetheless, these reviews were limited on the TCD of $\mathrm{CH}_{4}$ which heavily focussed on 119 catalysts to reactor's type. In recent years, there are distinct works that are focussed on the 120 feedstock combination with $\mathrm{CH}_{4}[22,23]$ which provide better conversions and improved the 121 activity and stability of the catalysts. Thus, in this review, an attempt has been made to review on 122 admixture feedstocks with $\mathrm{CH}_{4}$ with other hydrocarbons critically. Moreover, this article also 123 independently reviews on the type of catalysts, i.e. monometallic and multimetallic and their 124 performances in TCD of $\mathrm{CH}_{4}$. We also highlighted the outlook of TCD in directing the future 125 research in coming years. Fig. 1 shows a complete process that we take for this review article. 


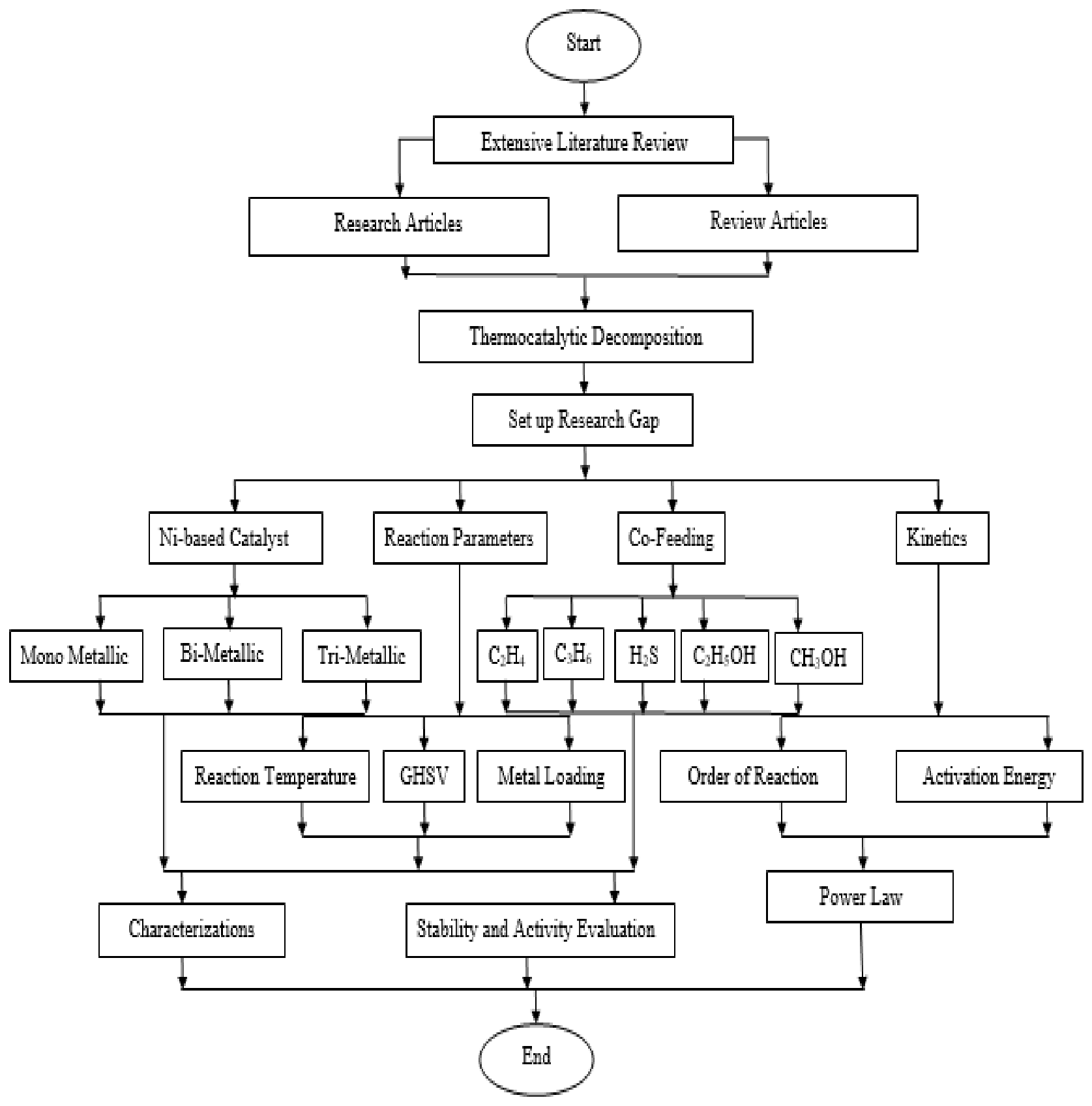




\section{Thermo-catalytic Decomposition (TCD) of $\mathrm{CH}_{4}$}

137 TCD of $\mathrm{CH}_{4}$ is a single step process which produces pure $\mathrm{H}_{2}$ and carbon as a by-product [14]. This 138 method is known as an eco-friendly process, and it has been extensively studied by various 139 researchers [24]. The main advantages of TCD include the greenhouse free $\mathrm{H}_{2}$ production that can

140 be directly used in fuel cells and the production of CNF as a by-product [25]. The reaction proceeds 141 as shown in Eqns. (1)-(6) [9].

$$
\mathrm{CH}_{4}\left(\text { gas) } \rightarrow \mathrm{C}_{(\mathrm{S})}+2 \mathrm{H}_{2} \text { (gas) } \quad \Delta \mathrm{H}=74.9 \mathrm{kJmol}^{-1}\right.
$$

142 The reaction occurs in four stages explained as:

143 (a) In the first step, the $\mathrm{CH}_{4}$ gets itself attached to the surface of the catalyst. The most 144 important part of the catalyst contains the metal impregnated with suitable support and $145 \quad$ promoters.

$$
\mathrm{CH}_{4}\left(\text { gas) } \rightarrow \mathrm{CH}_{3} \text { (ads) }+\mathrm{H}_{(\text {ads })}\right.
$$

(b) The breaking of $\mathrm{sp}^{3}$ hybridized C-H bonds occurs. This is the most critical step since high energy is required to break strongly attached bonds.

$$
\begin{aligned}
& \mathrm{CH}_{3(\text { ads })} \rightarrow \mathrm{CH}_{2(\text { ads })}+\mathrm{H}_{(\text {ads })} \\
& \mathrm{CH}_{2(\text { ads })} \rightarrow \mathrm{CH}_{(\text {ads })}+\mathrm{H}_{(\text {ads })}
\end{aligned}
$$

(c) After the breakage of these bonds, the $\mathrm{H}$ converts into the molecular form thus becoming a primary product.

$$
\mathrm{H}_{(\mathrm{ads})}+\mathrm{H}_{(\mathrm{ads})} \rightarrow \mathrm{H}_{2}(\mathrm{Gas})
$$

(d) The next step is the attachment of carbon on the surface of active sites. Hence, the active sites blocked, and the surface area of the catalyst is also decreased. Therefore, it is observed that the initial deactivation of the catalyst starts. 


$$
\mathrm{CH}_{(\text {ads })} \rightarrow \mathrm{C}_{(\text {(Solid })}+\mathrm{H}_{(\text {ads })}
$$

(e) The last step is the forming of carbon nuclei on the surface of the catalyst. Carbons get the form of MWCNT, CNF or BCNF depending upon nature and the operating conditions.

TCD is an endothermic reaction and occurs at high temperatures, i.e. $1473 \mathrm{~K}$ due to the highly stable tetrahedral structure of $\mathrm{CH}_{4}$ molecule supported by extremely stable $\mathrm{C}-\mathrm{H}$ bonds with a bond energy of $434 \mathrm{kJmol}^{-1}$. Therefore, the applications of catalyst are mandatory to provide a robust pathway to decrease the activation energy [26]. To improve the reaction kinetics of TCD, Metalbased catalysts, and carbonaceous catalysts were introduced by numerous researchers. These include transition metal having partially filled d-orbital, activated carbon and carbon black [17].

\section{Catalysts Involved in TCD}

For commercially viable, the development of TCD process requires a low cost synthesized catalyst that results in higher and prolonged activities towards $\mathrm{CH}_{4}$ decomposition into $\mathrm{H}_{2}$ and elemental carbon. The literature survey on the study of the single metallic, bi-metallic and tri-metallic catalysts having different ratios in composition and synthesized by distinct techniques have been explained in Sections 2.1-2.3.

\subsection{Mono Metallic Catalyst}

Over the last few years, countless efforts have been made in the development of the preparation method of a suitable catalyst to optimize TCD of $\mathrm{CH}_{4}$ for $\mathrm{CO}_{\mathrm{X}}$ free $\mathrm{H}_{2}$. Various monometallic catalysts with different supports have been reported [27]. Apart from production of pure $\mathrm{H}_{2}$, the invention of highly ordered carbon in the form of carbon nanofiber $(\mathrm{CNF})$, carbon nanotubes (CNT), biwall carbon nanotubes (BWCNT), and multiwall carbon nanotubes (MWCNT) has been reported by researchers using these catalysts [28]. The morphology of the deposited carbon is 
175 mainly dependent upon the metal loadings and reaction parameters. Although the general 176 mechanism of TCD has been proposed to be similar for nearly all metallic materials, the catalytic 177 stability and activity is influenced by catalysis synthesis techniques, pre-treatment of catalyst and 178 most importantly the TCD parameters [24, 29]. Ni, Fe, and Co are the commonly used transition 179 metals impregnated on $\mathrm{Al}_{2} \mathrm{O}_{3}, \mathrm{SiO}_{2}, \mathrm{MgO}$ and $\mathrm{La}_{2} \mathrm{O}_{3}$ support [20].

180 Several investigators have reported productive work in bringing up the most optimized, reactive 181 and stable catalysts for TCD of $\mathrm{CH}_{4}$. Ni-based materials are often stated as one of the most active, 182 readily available and cost-effective catalysts for $\mathrm{CH}_{4}$ reforming processes. It is reported that the 183 performance of Ni-based catalysts is strongly dependent on the type of support it is impregnated 184 on as the structure and electronic state of the catalyst changes once the material is successfully 185 prepared. Therefore, it is worth mentioning that the best combination of $\mathrm{Ni}$ and apposite support 186 can produce a highly active and stable catalyst for TCD of $\mathrm{CH}_{4}$ [30]. Bayat et al. [31] studied 187 various $\mathrm{Ni}$ loading on $\gamma-\mathrm{Al}_{2} \mathrm{O}_{3}$ support. The results marked the catalysts as highly active and stable 188 in the stated field of study, but they were sensitive to metal loadings and reaction temperatures. 189 Owing to the endothermic nature of the reaction, the conversions of $\mathrm{CH}_{4}$ increased periodically 190 with reaction temperature. Moreover, it was also observed that at higher metal loadings the 191 conversions were also high due to the presence of ample amounts of $\mathrm{NiO}$ on the surface of the 192 support. The study done by Makvandi et al. [32] elaborated that the $\mathrm{CH}_{4}$ conversions declined with 193 TOS for $\mathrm{Ni} / \mathrm{Al}_{2} \mathrm{O}_{3}$ due to deposition of carbon on the active sites preventing the access of 194 hydrocarbon. Moreover, the conversions increased linearly with metal loadings due to the 195 availability of excessive active sites. The catalytic performance of $60 \% \mathrm{Ni} / \mathrm{Al}_{2} \mathrm{O}_{3}$ was inspected by 196 Ahmed et al. [33]. The results revealed that the textural properties play a vital role in the 
197 performance of the catalyst since nanoparticle (NP) gave the highest yields as compared to the 198 hollow sphere (HS) and bulk catalyst (BC).

199 Apart from $\mathrm{Al}_{2} \mathrm{O}_{3}$ being the most studied by many researchers, studies on $\mathrm{MgO}, \mathrm{SiO}_{2}, \mathrm{TiO}_{2}$, $200 \mathrm{MgAl}_{2} \mathrm{O}_{4}, \mathrm{La}_{2} \mathrm{O}_{3}, \mathrm{SBA}-15$, and $\mathrm{La}_{2} \mathrm{O}_{3}$ have also been cited on Ni-based catalyst [34, 35]. The 201 literature survey showed that $\mathrm{Ni} / \mathrm{SiO}_{2}$ catalyst presented notable conversions, but eventually the 202 catalyst deactivated due to the accumulation of carbon in the pores of the catalyst. TPO and TGA 203 analysis supported the formation of MWCNT as a by-product [36]. $\mathrm{TiO}_{2}$ was also reported to be 204 active support for TCD of $\mathrm{CH}_{4}$ due to its high surface area and pore volume. This assisted in a fine 205 dispersion of $\mathrm{Ni}$ creating vast amounts of $\mathrm{NiO}$ for $\mathrm{CH}_{4}$ breakage $[37,38]$. All $\mathrm{Ni}$ support $\mathrm{TiO}_{2}$ 206 catalyst was highly active for $\mathrm{CH}_{4}$ decomposition reaction due to proper metal support interaction 207 that also provided thermal stability to the catalyst.

208 Fe and Co-based materials are also classified as active metals for TCD of $\mathrm{CH}_{4}$. Besides Ni. Pinilla 209 and co-workers [39] came up with results which showed that high $\mathrm{CH}_{4}$ conversions are allowed 210 by Fe based catalyst at operating temperatures higher than $1073 \mathrm{~K}$. The researchers also compared 211 the catalytic efficiency of $\mathrm{Al}_{2} \mathrm{O}_{3}$ and $\mathrm{MgO}$ supports and ranked $\mathrm{Fe}$ impregnated on prior support as 212 more stable compared to later one. The influence of metal loading and the effects of support on Fe 213 based catalyst was again discussed briefly in [40]. Fe catalyst supported on $\mathrm{Al}_{2} \mathrm{O}_{3}$ showed high 214 conversions as compared to $\mathrm{MgO}$ and $\mathrm{TiO}_{2}$. The catalytic order w.r.t. support was as $\mathrm{Al}_{2} \mathrm{O}_{3}>\mathrm{MgO}$ $215>\mathrm{TiO}_{2}$. The performance of $\mathrm{Fe}$ supported on $\mathrm{Al}_{2} \mathrm{O}_{3}$ as an active catalyst for $\mathrm{TCD}$ of $\mathrm{CH}_{4}$ was also 216 acknowledged by [41]. The study of Ibrahim et al. [28] also justified that the $\mathrm{CH}_{4}$ conversions 217 increased with Fe loadings due to the availability of a large number of active sites and because of 218 right interaction in metal and support. The highest conversions were attained by $60 \% \mathrm{Fe} / \mathrm{Al}_{2} \mathrm{O}_{3}$. 
219 Co-based catalysts are also the area of several studies for optimization of TCD of natural gas into

$220 \mathrm{H}_{2}$ and elemental carbon. The formation of cobalt oxide, i.e. $\mathrm{Co}_{3} \mathrm{O}_{4}$ is the main reason for its 221 superior activity and stability of the catalyst [42]. It is also reported that the higher loading of Co 222 produces large CNF having bigger diameter due to the agglomeration of the particles [43]. Besides 223 the excellent performance of Co-based catalysts, its toxicity issues and higher cost as compared to 224 Ni restricts its usage in both industrial and domestic level [31].

225 The detailed performance analysis along with reaction conditions of some of the monometallic 226 catalysts has been summarized in Table 1. Moreover, the catalyst synthesis techniques and carbon 227 yield have also been presented. 
Table 1: Catalytic activity and stability of various monometallic catalyst having different supporters and reaction conditions in fixed bed reactor (FBR) for TCD

\begin{tabular}{|c|c|c|c|c|c|c|c|c|c|c|}
\hline S. No & Metal & Support & ${ }^{(\mathrm{a})} \mathrm{Wc}(\mathrm{g})$ & Preparation & S.A m ${ }^{2} \mathrm{~g}^{-}$ & ${ }^{(\mathrm{d})} \mathrm{T}_{\mathrm{R}}(\mathrm{K})$ & ${ }^{(\mathrm{e})} \mathrm{R}_{\mathrm{T}}(\mathrm{h})$ & Conversion/Yield (\%) & Carbon & Ref \\
\hline 1. & $10 \% \mathrm{Ni}$ & $\mathrm{Al}_{2} \mathrm{O}_{3}$ & 0.05 & I.M $^{(\mathrm{c})}$ & 141 & 853 & 1 & (g) 21 & - & [34] \\
\hline 2. & $10 \% \mathrm{Ni}$ & $\mathrm{MgAl}_{2} \mathrm{O}_{4}$ & 0.05 & $\mathrm{I} \mathrm{M}^{(\mathrm{c})}$ & 134 & 853 & 1 & (g) 12 & - & [34] \\
\hline 3. & $10 \% \mathrm{Ni}$ & $\mathrm{MgO}$ & 0.05 & I.M $\mathbf{M}^{(\mathrm{c})}$ & 90 & 853 & 1 & (g) 13 & - & [34] \\
\hline 4. & $14 \% \mathrm{Fe}$ & $\mathrm{CeO}_{2}$ & 0.15 & C.P ${ }^{(\mathrm{N})}$ & 11.7 & 1023 & 4 & (g) 03 & - & [44] \\
\hline 5. & $28 \% \mathrm{Fe}$ & $\mathrm{CeO}_{2}$ & 0.15 & C.P ${ }^{(\mathrm{N})}$ & 22.2 & 1023 & 4 & (g) 05 & - & [44] \\
\hline 6. & $42 \% \mathrm{Fe}$ & $\mathrm{CeO}_{2}$ & 0.15 & C.P ${ }^{(\mathrm{N})}$ & 51.3 & 1023 & 4 & (g) 26 & - & [44] \\
\hline 7. & $56 \% \mathrm{Fe}$ & $\mathrm{CeO}_{2}$ & 0.15 & C.P ${ }^{(\mathrm{N})}$ & 60.3 & 1023 & 4 & (g) 25 & - & [44] \\
\hline 8. & $70 \% \mathrm{Fe}$ & $\mathrm{CeO}_{2}$ & 0.15 & C.P ${ }^{(\mathrm{N})}$ & 69.5 & 1023 & 4 & (g) 10 & - & [44] \\
\hline 9. & $00 \% \mathrm{Fe}$ & $\mathrm{CeO}_{2}$ & 0.15 & C.P ${ }^{(\mathrm{N})}$ & 100.2 & 1023 & 4 & ${ }^{(\mathrm{g})} 01$ & - & [44] \\
\hline 10. & $67 \% \mathrm{Fe}$ & $\mathrm{Al}_{2} \mathrm{O}_{3}$ & 0.15 & I. $\mathbf{M}^{(\mathrm{c})}$ & 141.6 & 1073 & 3 & ${ }^{(\mathrm{f})} 28$ & - & [39] \\
\hline 11. & $67 \% \mathrm{Fe}$ & $\mathrm{MgO}$ & 0.15 & $\mathrm{I} \mathrm{M}^{(\mathrm{c})}$ & 14.7 & 1073 & 3 & ${ }^{(\mathrm{f})} 20$ & - & [39] \\
\hline 12. & $05 \% \mathrm{Ni}$ & $\mathrm{Al}_{2} \mathrm{O}_{3}$ & 0.15 & I.M $\mathbf{M}^{(\mathrm{c})}$ & 249 & 973 & 4 & ${ }^{(\mathrm{g})} 10$ & - & [32] \\
\hline 13. & $7.5 \% \mathrm{Ni}$ & $\mathrm{Al}_{2} \mathrm{O}_{3}$ & 0.15 & I.M $\mathbf{M}^{(\mathrm{c})}$ & 248 & 973 & 4 & ${ }^{(\mathrm{g})} 18$ & - & [32] \\
\hline 14. & $10 \% \mathrm{Ni}$ & $\mathrm{Al}_{2} \mathrm{O}_{3}$ & 0.15 & I. $\mathrm{M}^{(\mathrm{c})}$ & 245 & 973 & 4 & (g) 29 & - & [32] \\
\hline 15. & $50 \%$ Co & $\mathrm{MgO}$ & 0.5 & I. $\mathbf{M}^{(\mathrm{c})}$ & 20.4 & 973 & 7 & ${ }^{(\mathrm{g})} 83$ & (i) 261 & [45] \\
\hline 16. & $50 \% \mathrm{Fe}$ & $\mathrm{MgO}$ & 0.5 & I.M $\mathbf{M}^{(\mathrm{c})}$ & 18.68 & 973 & 8 & (f) 40 & (i) 599 & [46] \\
\hline 17. & $50 \% \mathrm{Ni}$ & $\mathrm{MgO}$ & 0.5 & $\mathrm{I} \mathrm{M}^{(\mathrm{c})}$ & 28.12 & 973 & 8 & (f) 15 & (i) 139 & [46] \\
\hline 18. & $50 \%$ Co & $\mathrm{MgO}$ & 0.5 & $\mathrm{I}^{\mathrm{M}} \mathrm{M}^{(\mathrm{c})}$ & 28.25 & 973 & 8 & (f) 90 & (i) 1121 & [46] \\
\hline
\end{tabular}




\begin{tabular}{|c|c|c|c|c|c|c|c|c|c|c|}
\hline S. No & Metal & Support & ${ }^{(a)} W c(g)$ & Preparation & $\begin{array}{l}\text { S.A m }{ }^{2} \mathrm{~g}^{-} \\
\end{array}$ & ${ }^{(\mathrm{d})} \mathrm{T}_{\mathrm{R}}(\mathrm{K})$ & ${ }^{(\mathrm{e})} \mathrm{R}_{\mathrm{T}}(\mathrm{h})$ & Conversion/Yield (\%) & Carbon & Ref \\
\hline 20. & $\mathrm{Ni}$ & $\mathrm{SiO}_{2}$ & 3 & S.G ${ }^{(0)}$ & - & 1073 & 5 & (f) 50 & (i) 215 & [47] \\
\hline 19. & Co & $\mathrm{SiO}_{2}$ & 3 & S.G ${ }^{(0)}$ & - & 1073 & 5 & (f) 47 & (i) 156 & [47] \\
\hline 21. & $\mathrm{Fe}$ & $\mathrm{SiO}_{2}$ & 3 & S.G ${ }^{(0)}$ & - & 1073 & 5 & (f) 48 & (i) 177 & [47] \\
\hline 22. & $15 \% \mathrm{Fe}$ & $\mathrm{SiO}_{2}$ & 0.3 & $\mathrm{I}_{\mathrm{M}} \mathrm{M}^{(\mathrm{c})}$ & 179.3 & 973 & 4 & (f) 4 & - & [28] \\
\hline 23. & $25 \% \mathrm{Fe}$ & $\mathrm{SiO}_{2}$ & 0.3 & I. $\mathrm{M}^{(\mathrm{c})}$ & 141 & 973 & 4 & (f) 12 & - & [28] \\
\hline 24. & $35 \% \mathrm{Fe}$ & $\mathrm{SiO}_{2}$ & 0.3 & $\mathrm{I} . \mathrm{M}^{(\mathrm{c})}$ & 135 & 973 & 4 & (f) 15 & - & [28] \\
\hline 25. & $40 \% \mathrm{Fe}$ & $\mathrm{SiO}_{2}$ & 0.3 & $\mathrm{I} . \mathrm{M}^{(\mathrm{c})}$ & 129.5 & 973 & 4 & (f) 54 & - & [28] \\
\hline \multirow[t]{2}{*}{26.} & $60 \% \mathrm{Fe}$ & $\mathrm{SiO}_{2}$ & 0.3 & $\mathrm{I} . \mathrm{M}^{(\mathrm{c})}$ & 112.6 & 973 & 4 & (f) 71 & - & [28] \\
\hline & & & & & & 973 & & & & \\
\hline 27. & $80 \% \mathrm{Fe}$ & $\mathrm{SiO}_{2}$ & 0.3 & I. M ${ }^{(c)}$ & 51.9 & 973 & 4 & (f) 74 & - & [28] \\
\hline 28. & $100 \% \mathrm{Fe}$ & $\mathrm{SiO}_{2}$ & 0.3 & $\mathrm{I}^{\mathrm{M}} \mathrm{M}^{(\mathrm{c})}$ & 5.4 & 973 & 4 & (f) 78 & - & [28] \\
\hline 29. & $50 \% \mathrm{Ni}$ & $\mathrm{MgO}$ & 0.5 & I. M ${ }^{(c)}$ & - & 973 & 7 & (f) 14 & - & [48] \\
\hline 30. & $10 \% \mathrm{Fe}$ & $\mathrm{Al}_{2} \mathrm{O}_{3}$ & 0.3 & $\mathrm{I}^{\mathrm{I}} \mathrm{M}^{(\mathrm{c})}$ & 222.5 & 973 & 3 & (g) 9 & - & [40] \\
\hline 31. & $20 \% \mathrm{Fe}$ & $\mathrm{Al}_{2} \mathrm{O}_{3}$ & 0.3 & $\mathrm{I}^{\mathrm{I}} \mathrm{M}^{(\mathrm{c})}$ & 237 & 973 & 3 & (g) 35 & - & [40] \\
\hline 32. & $30 \% \mathrm{Fe}$ & $\mathrm{Al}_{2} \mathrm{O}_{3}$ & 0.3 & $\mathrm{I}^{\mathrm{I}} \mathrm{M}^{(\mathrm{c})}$ & 203 & 973 & 3 & (g) 42 & - & [40] \\
\hline 33. & $40 \% \mathrm{Fe}$ & $\mathrm{Al}_{2} \mathrm{O}_{3}$ & 0.3 & $\mathrm{I}^{\mathrm{I}} \mathrm{M}^{(\mathrm{c})}$ & 184.8 & 973 & 3 & (g) 43 & - & [40] \\
\hline 34. & $50 \% \mathrm{Fe}$ & $\mathrm{Al}_{2} \mathrm{O}_{3}$ & 0.3 & $\mathrm{I}^{\mathrm{I}} \mathrm{M}^{(\mathrm{c})}$ & 176.2 & 973 & 3 & (g) 45 & - & [40] \\
\hline 35. & $10 \% \mathrm{Fe}$ & $\mathrm{MgO}$ & 0.3 & $\mathrm{I}^{\mathrm{I}} \mathrm{M}^{(\mathrm{c})}$ & 125.1 & 973 & 3 & (g) 44 & - & [40] \\
\hline 36. & $15 \% \mathrm{Fe}$ & $\mathrm{MgO}$ & 0.3 & $\mathrm{I}^{\mathrm{I}} \mathrm{M}^{(\mathrm{c})}$ & 120.8 & 973 & 3 & (g) 47 & - & [40] \\
\hline 37. & $20 \% \mathrm{Fe}$ & $\mathrm{MgO}$ & 0.3 & $\mathrm{I} . \mathrm{M}^{(\mathrm{c})}$ & 105.8 & 973 & 3 & (g) 46 & - & [40] \\
\hline
\end{tabular}




\begin{tabular}{|c|c|c|c|c|c|c|c|c|c|c|}
\hline S. No & Metal & Support & ${ }^{(a)} W_{c}(g)$ & Preparation & $\begin{array}{l}\text { S.A m }{ }^{2} \mathrm{~g}^{-} \\
1\end{array}$ & ${ }^{(\mathrm{d})} \mathrm{T}_{\mathrm{R}}(\mathrm{K})$ & ${ }^{(\mathrm{e})} \mathrm{R}_{\mathrm{T}}$ (h) & Conversion/Yield (\%) & Carbon & Ref \\
\hline 38. & $30 \% \mathrm{Fe}$ & $\mathrm{MgO}$ & 0.3 & I.M ${ }^{(c)}$ & 97.2 & 973 & 3 & (g) 45 & - & [40] \\
\hline 39. & $40 \% \mathrm{Fe}$ & $\mathrm{MgO}$ & 0.3 & I. $\mathrm{M}^{(\mathrm{c})}$ & 46.9 & 973 & 3 & (g) 40 & - & [40] \\
\hline 40. & $20 \% \mathrm{Fe}$ & $\mathrm{TiO}_{2}$ & 0.3 & I. $\mathrm{M}^{(\mathrm{c})}$ & 96.2 & 973 & 3 & (g) 14 & - & [40] \\
\hline 41. & $30 \% \mathrm{Fe}$ & $\mathrm{TiO}_{2}$ & 0.3 & I.M ${ }^{(c)}$ & 92 & 973 & 3 & (g) 15 & - & [40] \\
\hline 42. & $40 \% \mathrm{Fe}$ & $\mathrm{TiO}_{2}$ & 0.3 & I. $\mathrm{M}^{(\mathrm{c})}$ & 76 & 973 & 3 & (g) 16 & - & [40] \\
\hline 43. & $50 \% \mathrm{Fe}$ & $\mathrm{TiO}_{2}$ & 0.3 & I. $\mathrm{M}^{(\mathrm{c})}$ & 75.9 & 973 & 3 & (g) 17 & - & [40] \\
\hline 44. & $50 \% \mathrm{Ni}$ & SBA-15 & 1 & I. $M^{(c)}$ & 182.6 & 973 & 7 & (f) 40 & - & [49] \\
\hline 45. & $\mathrm{Ni}$ & $\mathrm{MgAl}_{2} \mathrm{O}_{4}$ & 1 & - & 22.63 & 973 & 7 & ${ }^{(\mathrm{f})} 34$ & - & [50] \\
\hline 46. & $50 \%$ Co & $\mathrm{Al}_{2} \mathrm{O}_{3}$ & 0.5 & I. $\mathrm{M}^{(\mathrm{c})}$ & 24.2 & 973 & 7 & ${ }^{(\mathrm{f})} 88$ & (i) 298 & [51] \\
\hline 47. & $50 \%$ Co & $\mathrm{SiO}_{2}$ & 0.5 & I. $\mathrm{M}^{(\mathrm{c})}$ & 93.2 & 973 & 7 & (f) 48 & (i) 172 & [51] \\
\hline 48. & $50 \%$ Co & $\mathrm{MgO}$ & 0.5 & I. $\mathrm{M}^{(\mathrm{c})}$ & 20.1 & 973 & 7 & ${ }^{(\mathrm{f})} 73$ & (i) 1121 & [51] \\
\hline 49. & $30 \% \mathrm{Ni}$ & $\mathrm{Al}_{2} \mathrm{O}_{3}$ & 0.05 & I. $\mathrm{M}^{(\mathrm{c})}$ & 121.3 & 973 & 5 & - & - & [31] \\
\hline 50. & $40 \% \mathrm{Ni}$ & $\mathrm{Al}_{2} \mathrm{O}_{3}$ & 0.05 & I. $\mathrm{M}^{(\mathrm{c})}$ & 105.6 & 973 & 5 & - & - & [31] \\
\hline 51. & $50 \% \mathrm{Ni}$ & $\mathrm{Al}_{2} \mathrm{O}_{3}$ & 0.05 & I.M ${ }^{(c)}$ & 89.2 & 973 & 5 & - & - & [31] \\
\hline 52. & $60 \% \mathrm{Ni}$ & $\mathrm{Al}_{2} \mathrm{O}_{3}$ & 0.05 & I. $\mathrm{M}^{(\mathrm{c})}$ & 66.1 & 973 & 5 & - & - & [31] \\
\hline 53. & $60 \% \mathrm{Ni}(\mathrm{N} . \mathrm{P})^{(\mathrm{K})}$ & $\mathrm{Al}_{2} \mathrm{O}_{3}$ & 0.5 & - & 58.7 & 973 & 6 & ${ }^{(\mathrm{f})} 60$ & - & [33] \\
\hline 54. & $60 \% \mathrm{Ni}(\mathrm{B})^{(\mathrm{L})}$ & $\mathrm{Al}_{2} \mathrm{O}_{3}$ & 0.5 & - & 22.8 & 973 & 6 & ${ }^{(\mathrm{f})} 50$ & - & [33] \\
\hline 55. & $60 \% \mathrm{Ni}(\mathrm{H} . \mathrm{S})^{(\mathrm{M})}$ & $\mathrm{Al}_{2} \mathrm{O}_{3}$ & 0.5 & - & 22.0 & 973 & 6 & ${ }^{(\mathrm{f})} 19$ & - & [33] \\
\hline 56. & $5 \%$ Co & $\mathrm{SiO}_{2}$ & - & I.M (c) $^{(\text {) }}$ & 382 & - & 3 & - & - & [52] \\
\hline 57. & $10 \%$ Со & $\mathrm{SiO}_{2}$ & - & I. $\mathrm{M}^{(\mathrm{c})}$ & 351 & - & 3 & - & - & [52] \\
\hline
\end{tabular}




\begin{tabular}{|c|c|c|c|c|c|c|c|c|c|c|}
\hline S. No & Metal & Support & ${ }^{(a)} \mathrm{Wc}(\mathrm{g})$ & Preparation & $\begin{array}{l}\text { S.A m }{ }^{2} \mathrm{~g}^{-} \\
1\end{array}$ & ${ }^{\left({ }^{(d)} T_{R}(K)\right.}$ & ${ }^{(\mathrm{e})} \mathrm{R}_{\mathrm{T}}(\mathrm{h})$ & Conversion/Yield (\%) & Carbon & Ref \\
\hline 58. & $20 \% \mathrm{Co}$ & $\mathrm{SiO}_{2}$ & - & I. $\mathrm{M}^{(\mathrm{c})}$ & 292 & - & 3 & - & - & [52] \\
\hline 59. & $5 \% \mathrm{Co}$ & $\mathrm{Al}_{2} \mathrm{O}_{3}$ & - & I. $\mathrm{M}^{(\mathrm{c})}$ & 227 & - & 3 & - & - & [52] \\
\hline 60. & $10 \% \mathrm{Co}$ & $\mathrm{Al}_{2} \mathrm{O}_{3}$ & - & I. $\mathrm{M}^{(\mathrm{c})}$ & 27.4 & - & 3 & - & - & [52] \\
\hline 61. & $30 \% \mathrm{Fe}$ & $\mathrm{Al}_{2} \mathrm{O}_{3}$ & 0.3 & I. M ${ }^{(c)}$ & 150.1 & 973 & 3 & (g) 68 & - & [53] \\
\hline 62. & - & $\mathrm{NiO}$ & 2 & - & 25.4 & 1073 & 6 & ${ }^{(\mathrm{f})} 62$ & (i) 263 & [54] \\
\hline 63. & - & $\mathrm{Fe}_{2} \mathrm{O}_{3}$ & 2 & - & 13.8 & 1073 & 6 & (f) 50 & (i) 147 & [54] \\
\hline 64. & $20 \% \mathrm{Ni}$ & $\mathrm{CeO}_{2}$ & 2 & - & 42.1 & 973 & 6 & ${ }^{(\mathrm{f})} 62$ & (i) 1360 & [35] \\
\hline 65. & $20 \% \mathrm{Ni}$ & $\mathrm{ZrO}_{2}$ & 2 & - & 23.8 & 973 & 6 & ${ }^{(\mathrm{f})} 61$ & (i) 1159 & [35] \\
\hline 66. & $20 \% \mathrm{Ni}$ & $\mathrm{La}_{2} \mathrm{O}_{3}$ & 2 & - & 10.6 & 973 & 6 & ${ }^{(\mathrm{f})} 68$ & (i) 1576 & [35] \\
\hline 67. & $\mathrm{Ni}$ & $\mathrm{Al}_{2} \mathrm{O}_{3}$ & - & I. M ${ }^{(c)}$ & 201.03 & 1073 & 4 & (g) 15.33 & - & [55] \\
\hline 68. & $\mathrm{Pd}$ & $\mathrm{Al}_{2} \mathrm{O}_{3}$ & - & I. M ${ }^{(c)}$ & 195.31 & 1073 & 4 & (g) 15.68 & - & [55] \\
\hline 69. & $10 \% \mathrm{Ni}$ & $\mathrm{TiO}_{2}$ & 1 & I. M ${ }^{(c)}$ & 23.68 & 973 & 6 & (f) 27 & (i) 1399 & [37] \\
\hline 70. & $20 \% \mathrm{Ni}$ & $\mathrm{TiO}_{2}$ & 1 & I. M ${ }^{(c)}$ & 18.49 & 973 & 6 & (f) 30 & (i) 1180 & [37] \\
\hline 71. & $30 \% \mathrm{Ni}$ & $\mathrm{TiO}_{2}$ & 1 & I. M ${ }^{(c)}$ & 12.31 & 973 & 6 & (f) 33 & (i) 1380 & [37] \\
\hline 72. & $40 \% \mathrm{Ni}$ & $\mathrm{TiO}_{2}$ & 1 & I. M ${ }^{(c)}$ & - & 973 & 6 & (f) 37 & (i) 1522 & [37] \\
\hline 73. & $50 \% \mathrm{Ni}$ & $\mathrm{TiO}_{2}$ & 1 & I. M ${ }^{(c)}$ & - & 973 & 6 & (f) 42 & (i) 1544 & [37] \\
\hline 74. & $\mathrm{Ni}$ & $\mathrm{MgO}$ & 1 & I. M ${ }^{(c)}$ & 24.20 & 1073 & 6 & (f) 37 & (i) 850 & [56] \\
\hline 75. & $5 \% \mathrm{Fe}$ & $\mathrm{MgO}$ & 0.5 & I. M ${ }^{(c)}$ & 79 & 1173 & - & - & (i) 4.7 & [57] \\
\hline
\end{tabular}

(a)Weight of catalyst (b) Fusion method (c) Impregnation method (d) Reaction temperature (e) Reaction Time (f) $\mathrm{H}_{2}$ yield (g) Methane (h) g c/g ni (i) \% (J) mg (K) Nano particle (L) Bulk (M) Hollow Sphere (N) Co Precipitation (O) Sol Gel 


\subsection{Bi-Metallic Catalyst}

The transition metals such as $\mathrm{Ni}, \mathrm{Fe}$, and $\mathrm{Co}$ as explained in Section 2.1 have shown better performance as active metal precursors for TCD of $\mathrm{CH}_{4}$ into $\mathrm{CO}_{\mathrm{X}}$ free $\mathrm{H}_{2}$ and $\mathrm{CNF}$ [58]. The deactivation of this catalyst at high temperatures is due to the encapsulation of nearly in active carbon. This has opened new horizons of research in this field (c.f. Table 1). The modification of Ni-based catalyst with other transition metals is reported to be a viable solution to this problem [59]. The impregnation of a second metal on Ni provides significant changes in its activity and stability due to alloying effect [45] (c.f. Tables 2 and 3).

To optimize the TCD of $\mathrm{CH}_{4}$, innumerable Ni-based bimetallic catalysts supported on $\gamma-\mathrm{Al}_{2} \mathrm{O}_{3}$ were employed. It was reported that $\mathrm{Ni}$ acts as an active phase and $\mathrm{Al}_{2} \mathrm{O}_{3}$ being inactive, which aids the dispersion of $\mathrm{Ni}$-containing phases. Interestingly, inactive $\mathrm{Al}_{2} \mathrm{O}_{3}$ proved to be responsible for most of the mechanical properties exhibited by the catalyst [60]. Echegoyen et al. [61] reported that the addition of textural promoter in Ni-based catalyst prevent from sintering. The group synthesized $\mathrm{Cu}$ promoted catalyst supported on $\mathrm{MgO}$. The presence of $\mathrm{Cu}$ enhanced the catalytic stability of the catalyst for $8 \mathrm{~h}$. Cu itself is inactive for TCD of $\mathrm{CH}_{4}$. The basic function is to aid $\mathrm{CNF}$ formation and increase the carbon diffusion rate, thus keeping the surface of $\mathrm{Ni}$ fresh for $\mathrm{CH}_{4}$ adsorption. Moreover, $\mathrm{Cu}$ promoted catalyst results in the formation of broader and lengthier CNF as a by-product [62]. A further study from [63] concluded that $\mathrm{TiO}_{2}$ could also use as textural support on high loading bimetallic catalyst and presence of $\mathrm{Cu}$ as promoter either in the form of oxide or nitrate enhance conversions of $\mathrm{CH}_{4}$ and carbon formations.

The influence of Mo on the catalytic efficiency of $\mathrm{Ni} / \mathrm{Al}_{2} \mathrm{O}_{3}$ was investigated in [64]. The results showed that addition of Mo with other transition metals improves $\mathrm{CH}_{4}$ conversions and $\mathrm{CNT}$ production as carbon bundles. Another critical aspect of Mo is its reduction to molybdenum 
carbides at the initial stages of the reaction. $\mathrm{Ni}$ and Mo both serve $\mathrm{TCD}$ of $\mathrm{CH}_{4}$ and $\mathrm{CNT}$ formation in different ways. The former is responsible for the dissociation of $\mathrm{CH}_{4}$ into $\mathrm{H}_{2}$ and elemental carbon while the latter serves as a reservoir for carbon diffusion. The presence of Mo as a promoter impregnated on $\mathrm{Al}_{2} \mathrm{O}_{3}$ in $\mathrm{Ni}$-based catalysts provided strong MSI and minimized sintering of material and ultimately increase the catalytic stability [65]. It was also observed in the above study that TCD of $\mathrm{CH}_{4}$ is not affected by the surface measurements of the catalyst [65].

Awadallah et al. [43] studied the effects of Co loadings on $\mathrm{Mo} / \mathrm{Al}_{2} \mathrm{O}_{3}$. The results summarized that $\mathrm{CH}_{4}$ conversions and diameter of CNF increased intermittently with higher metal loadings despite the decline in surface area which confirmed that TCD is a metal-catalyzed reaction. The presence of ample amount of $\mathrm{Co}_{3} \mathrm{O}_{4}$ on the surface of the catalyst boosted the catalyst stability. The transition metals of group VI (Mo, Cr, W) were impregnated with $\mathrm{Co} / \mathrm{MgO}$ [45]. The results revealed that the $\mathrm{CH}_{4}$ decompositions were stable for longer runs due to the formation of mixed oxides, i.e. $\mathrm{CoMO}_{4}$ and $\mathrm{CoWO}_{4}$ which increased the dispersion and stabilization of Co particles. The carbon yield exhibited was in the order of $\mathrm{Mo}>\mathrm{W}>\mathrm{Cr}$. Bimetallic metals of group VIII Ni, Fe and Co supported on $\mathrm{MgO}$ with a total metal content of 50\%. They were tested for non-oxidative decomposition of $\mathrm{CH}_{4}$ [48]. $\mathrm{Fe}-\mathrm{Co} / \mathrm{MgO}$ achieved the highest catalytic stability due to the presence of $\mathrm{Fe}_{2} \mathrm{O}_{3}$ and $\mathrm{Co}_{3} \mathrm{O}_{4}$ on the surface of $\mathrm{MgO}$ resulting in higher adsorption and solubility of $\mathrm{CH}_{4}$. Besides these results, the $\mathrm{CH}_{4}$ decompositions declined for $\mathrm{Ni}-\mathrm{Fe}$ and $\mathrm{Ni}-\mathrm{Co}$ based catalyst due to the formation on stable, robust solution $\mathrm{Mg}_{x} \mathrm{Ni}(1-\mathrm{x}) \mathrm{O}$. The authors believed that it was difficult to remove $\mathrm{Ni}$ species from inactive $\mathrm{Mg}{ }_{x} \mathrm{Ni}$ (1-x) $\mathrm{O}$ because of powerful MSI. Additionally, RAMAN revealed that the degree of graphitization and crystallinity was high in $\mathrm{Fe}-\mathrm{Co} / \mathrm{MgO}$ as compared to the Ni-based catalyst. 
Reasonable results were reported elsewhere [42] as $\mathrm{CH}_{4}$ conversions increased with higher loadings of cobalt in $\mathrm{Co}-\mathrm{W} / \mathrm{MgO}$. Presence of large quantities of $\mathrm{Co}$ on the surface of the $\mathrm{MgO}$ was the primary reason for substantial diffusion of feedstock. Ahmad et al. [66] highlighted the effects of varying the composition of catalyst support on $50 \%$ Ni-based catalyst. Different compositions of $\mathrm{CeO}_{2}$ and $\mathrm{Al}_{2} \mathrm{O}_{3}$ as catalyst supporters were synthesized by co-precipitation method and later were impregnated with $50 \% \mathrm{Ni}$. The conversions of $\mathrm{CH}_{4}$ are strongly dependent on the amount of $\mathrm{CeO}_{2}$ in the catalyst while it also affected the surface properties. The addition of $\mathrm{CeO}_{2}$ to $\mathrm{Al}_{2} \mathrm{O}_{3}$ avoided the formation of inactive $\mathrm{NiAl}_{2} \mathrm{O}_{4}$ as confirmed by TPR analysis.

Apart from $\mathrm{Ni}$, numerous works have been done on investigating the stability and activity of the Fe-based catalyst. Al-Fatesh et al. [67] studied the effects of modifying Fe/MgO catalyst by Ni, Co and $\mathrm{Mn}$ additives. Both $\mathrm{CH}_{4}$ conversions and $\mathrm{H}_{2}$ yields were enhanced in the presence of metal additives in the order of $\mathrm{Ni}>\mathrm{Co}>\mathrm{Mn}$. It is believed that the catalytic activity is rational to the surface area of the catalyst. However, the authors observed that the activities are dependent on the interaction between metal additives and the availability of active sites. Some other similar studies were also given elsewhere [65].

Ahmad et al. [68] worked on $\mathrm{Ce}$ and $\mathrm{Co}$-based $\mathrm{Fe} / \mathrm{Al}_{2} \mathrm{O}_{3}$. It was concluded that the catalyst reduced at higher temperature showed a decline in performance due to the sintering of the active sites. Furthermore, the addition of $\mathrm{Co}$ and $\mathrm{Ce}$ in the bimetallic catalyst provides two types of active sites thus favoring the reaction yields. Additionally, the conversions increased with higher Co loadings [29]. So, it was found that $15 \%$ Co coupled with $30 \% \mathrm{Fe} / \mathrm{Al}_{2} \mathrm{O}_{3}$ holds appropriate MSI and metal dispersion that leads to the excellent performance of the catalyst [53]. In another different study compositions of $\mathrm{Ni}$, Co over $\mathrm{Al}_{2} \mathrm{O}_{3}$ was studied for TCD of $\mathrm{CH}_{4}$. The best results were produced 
by using $25 \%$ each of $\mathrm{Ni}$ and $\mathrm{Co}(25 \% \mathrm{NiCoAl})$. The presence of Co-leads in the formation of thick wall highly stable MWCNT [69].

The same group of scholars [70] studied the effect of preparation method and calcination temperature on the catalytic stability of $\mathrm{Ni}-\mathrm{Fe} / \mathrm{Al}_{2} \mathrm{O}_{3}$. The results depicted that the $\mathrm{CH}_{4}$ conversions and carbon morphology is dependent on metal additives, synthesis procedure, and calcination temperatures. The impregnation method gave the highest yields as compared to coprecipitation and sol-gel method irrespective of the calcination temperatures. It was also noticeable that XRD analysis at higher calcination temperatures detected additional peaks of metal aluminates. Wasim et al. [71, 72] employed $\mathrm{La}_{2} \mathrm{O}_{3}$ as catalyst support for $\mathrm{Ni}-\mathrm{Co}$ catalyst. $12.5 \%$ of $\mathrm{Ni}$ and Co were found to be the optimum composition of the catalyst. The conversions were directly proportional to the reaction temperature owing to the endothermic nature of the reaction while declined with the rise in GHSV. The authors reported CDM as a four-step mechanism which included breakage of $\mathrm{CH}_{4}$ bonds, the release of $\mathrm{H}_{2}$, carbon diffusion and formation and accumulation of $\mathrm{CNF}$ over the surface of the catalyst. Moreover, the rise in calcination temperatures also affected the catalytic performance due to the destruction of active sites of the catalyst.

The study on optimizing TCD of $\mathrm{CH}_{4}$ over bimetallic catalyst was carried on by Bayat et al. [73] with different catalyst compositions and metal additives. The authors impregnated $\mathrm{Cu}$ with $\mathrm{Ni} / \mathrm{Al}_{2} \mathrm{O}_{3}$. The study revealed that the addition of $\mathrm{Cu}$ as promoter enhance TCD in several ways including high metal dispersion, reducibility, and rates of $\mathrm{CH}_{4}$ adsorption. Moreover, the high affinity of $\mathrm{Cu}$ with graphene inhibits the formation of encapsulating carbon and keeps the $\mathrm{Ni}$ surface fresh for $\mathrm{CH}_{4}$ diffusions [74]. This observation was also seen in the study made by Kumar et al. [75]. The successful impregnation of $\mathrm{Ni}$ and $\mathrm{Cu}$ on $\mathrm{Al}_{2} \mathrm{O}_{3}$ synthesized formerly by sol-gel 
method resulted in the formation of mixed oxides $\mathrm{Ni}_{x} \mathrm{Cu}_{(1-x)} \mathrm{O}$ species and $\mathrm{Ni}-\mathrm{Cu}$ alloy in the calcined and reduced catalyst. Along with $\mathrm{Cu}, \mathrm{Pd}$ is also regarded as a strong promoter in catalytic decomposition of $\mathrm{CH}_{4}$ into $\mathrm{CO}_{\mathrm{X}}$ free $\mathrm{H}_{2}$ and $\mathrm{CNF}$. Improved catalytic activity and thermal stability are the results of impregnating Pd on Ni-based catalysts [55]. Bayat et al. [76] suggested that the rate of carbon diffusion in Pd is faster as compared to Ni. This aspect results in increasing the diffusion rate of carbon inhibits the formation of encapsulating carbon over Ni. Additionally, during CDM reaction carbon grows from several facets of $\mathrm{Ni}-\mathrm{Pd}$ alloy forming branched carbon that boosts up catalyst stability and activity. Supportive results were elaborated by the same group in which the authors impregnated $\mathrm{Fe}$ on $\mathrm{Ni} / \mathrm{Al}_{2} \mathrm{O}_{3}$ [77]. The addition of $\mathrm{Fe}$ improved the conversions at higher temperatures due to its high ability to diffuse carbon thus avoiding the formation of encapsulating carbon. It is also reported that though Fe based catalyst results in fewer conversions as compared to Ni-based. Since the diffusion rate of carbon in the former catalyst is much higher compared to the later one [78]. Many studies have been devoted to modifying the supports by co-precipitating a couple of oxides together. Ahmad et al. [66] synthesized $\mathrm{CeO}_{2}-\mathrm{Al}_{2} \mathrm{O}_{3}$ as a catalyst support and demonstrated that the conversion of $\mathrm{CH}_{4}$ was mostly dependent on $\mathrm{CeO}_{2}$ content. In another work by Rastegarpanah et al. [79, 80], it was concluded that $\mathrm{MgO}-\mathrm{Al}_{2} \mathrm{O}_{3}$ performed well under a specified set of conditions. The effects of $\mathrm{TiO}_{2}-\mathrm{Al}_{2} \mathrm{O}_{3}$ were also reported by [38]. The catalytic activity and stability of various catalyst having different supporters and reaction conditions in FBR in TCD for bimetallic catalyst have been furnished in Table 2. 
Table 2: Catalytic activity and stability of various catalysts having different supporters and reaction conditions in FBR in TCD

\begin{tabular}{|c|c|c|c|c|c|c|c|c|c|c|}
\hline S. No & Metal & Support & $\begin{array}{l}{ }^{(\mathrm{a})} \mathrm{Wc} \\
\text { (g) }\end{array}$ & Preparation & $\begin{array}{l}\text { S.A } \\
\mathrm{m}^{2} \mathrm{~g}^{-1}\end{array}$ & ${ }^{(\mathrm{d})} \mathrm{T}_{\mathrm{R}}(\mathrm{K})$ & $\begin{array}{l}{ }^{(\mathrm{e})} \mathrm{R}_{\mathrm{T}} \\
\text { (h) }\end{array}$ & $\begin{array}{l}\text { Conversion/Yield } \\
(\%)\end{array}$ & Carbon & Ref \\
\hline 1. & $\mathrm{Ni}-\mathrm{Cu}$ & $\mathrm{Al}$ & 0.3 & F.M $\mathbf{M}^{(\mathrm{b})}$ & - & 973 & 8 & (f) 75 & - & [60] \\
\hline 2. & $\mathrm{Ni}-\mathrm{Cu}$ & $\mathrm{Mg}$ & 0.3 & F.M $\mathbf{M}^{(\mathrm{b})}$ & - & 1073 & 8 & (f) 79 & - & [61] \\
\hline 3. & $\mathrm{Ni}-\mathrm{Cu}$ & $\mathrm{SiO}_{2}$ & 0.3 & F.M $M^{(b)}$ & - & 1073 & 8 & (f) 79 & - & {$[62]$} \\
\hline 4. & $\mathrm{Ni}-\mathrm{Cu}$ & $\mathrm{TiO}_{2}$ & 0.3 & F.M $M^{(b)}$ & - & 1073 & 8 & (f) 80 & - & {$[63]$} \\
\hline 5. & $50 \% \mathrm{Fe}-5 \% \mathrm{Mo}$ & $\mathrm{Al}_{2} \mathrm{O}_{3}$ & 0.15 & I.M $M^{(c)}$ & 193 & 1073 & 3 & (f) 16 & (h) 5.9 & [39] \\
\hline 6. & $50 \% \mathrm{Fe}-7.5 \% \mathrm{Mo}$ & $\mathrm{MgO}$ & 0.15 & I. $\mathrm{M}^{(\mathrm{c})}$ & 15.3 & 1073 & 3 & (f) 28 & (h) 4.75 & [39] \\
\hline 7. & $\mathrm{Ni}-\mathrm{Cu}$ & $\mathrm{MgO}$ & 0.2 & I. $\mathrm{M}^{(\mathrm{c})}$ & - & 843 & 4 & (f) 58 & (h) 5.85 & [81] \\
\hline 8. & $\mathrm{Ni}-\mathrm{Mo}$ & $\mathrm{MgO}$ & 0.2 & I. $\mathrm{M}^{(\mathrm{c})}$ & - & 843 & 4 & (f) 15 & (h) 3.90 & [81] \\
\hline 9. & $\mathrm{Ni}-\mathrm{Co}$ & $\mathrm{MgO}$ & 0.2 & I. $\mathrm{M}^{(\mathrm{c})}$ & - & 843 & 4 & (f) 14 & - & [81] \\
\hline 10. & $\mathrm{Ni}-\mathrm{Mo}$ & $\mathrm{Al}_{2} \mathrm{O}_{3}$ & 0.5 & I. $M^{(c)}$ & - & 1073 & 8 & - & (i) 669 & [64] \\
\hline 11. & $5.2 \% \mathrm{Ni}-10.96 \% \mathrm{Mo}$ & $\mathrm{Al}_{2} \mathrm{O}_{3}$ & 0.5 & I. $\mathbf{M}^{(\mathrm{c})}$ & 127.9 & 973 & 8 & (f) 70 & (i) 341 & {$[65]$} \\
\hline 12. & $10 \% \mathrm{Ni}-9.5 \% \mathrm{Mo}$ & $\mathrm{Al}_{2} \mathrm{O}_{3}$ & 0.5 & I. M $^{(\mathrm{c})}$ & 101.2 & 973 & 8 & (f) 80 & (i) 612 & {$[65]$} \\
\hline 13. & $20 \% \mathrm{Ni}-8.5 \% \mathrm{Mo}$ & $\mathrm{Al}_{2} \mathrm{O}_{3}$ & 0.5 & $\mathrm{I} \mathrm{M}^{(\mathrm{c})}$ & 89.2 & 973 & 8 & (f) 81 & (i) 834 & [65] \\
\hline 14. & $30 \% \mathrm{Ni}-7.5 \% \mathrm{Mo}$ & $\mathrm{Al}_{2} \mathrm{O}_{3}$ & 0.5 & $\mathrm{I} \mathrm{M}^{(\mathrm{c})}$ & 91.3 & 973 & 8 & (f) 82 & (i) 1009 & [65] \\
\hline 15. & $40 \% \mathrm{Ni}-6.5 \% \mathrm{Mo}$ & $\mathrm{Al}_{2} \mathrm{O}_{3}$ & 0.5 & I.M $\mathbf{M}^{(\mathrm{c})}$ & 71.4 & 973 & 8 & (f) 82 & (i) 1379 & {$[65]$} \\
\hline 16. & $3.1 \% \mathrm{Co}^{-10.5 \% \mathrm{Mo}}$ & $\mathrm{Al}_{2} \mathrm{O}_{3}$ & 0.5 & I.M $\mathbf{M}^{(\mathrm{c})}$ & 190.9 & 973 & 8 & (f) 15 & (i) 55 & {$[43]$} \\
\hline 17. & $10 \% \mathrm{Co}-9.3 \% \mathrm{Mo}$ & $\mathrm{Al}_{2} \mathrm{O}_{3}$ & 0.5 & I. $\mathrm{M}^{(\mathrm{c})}$ & 177.4 & 973 & 8 & (f) 65 & (i) 762 & [43] \\
\hline
\end{tabular}




\begin{tabular}{|c|c|c|c|c|c|c|c|c|c|c|}
\hline S. No & Metal & Support & $\begin{array}{l}\left({ }^{(a)} \mathrm{Wc}\right. \\
(\mathrm{g})\end{array}$ & Preparation & $\begin{array}{l}\text { S.A } \\
m^{2} g^{-1}\end{array}$ & ${ }^{(\mathrm{d})} \mathrm{T}_{\mathrm{R}}(\mathrm{K})$ & $\begin{array}{l}{ }^{(\mathrm{e})} \mathrm{R}_{\mathrm{T}} \\
\text { (h) }\end{array}$ & $\begin{array}{l}\text { Conversion/Yield } \\
(\%)\end{array}$ & Carbon & Ref \\
\hline 18. & $20 \% \mathrm{Co}^{-8.3 \% \mathrm{Mo}}$ & $\mathrm{Al}_{2} \mathrm{O}_{3}$ & 0.5 & I.M (c) $^{(c)}$ & 143.9 & 973 & 8 & (f) 82 & (i) 456 & [43] \\
\hline 19. & $30 \% \mathrm{Co}^{-7.3 \% \mathrm{Mo}}$ & $\mathrm{Al}_{2} \mathrm{O}_{3}$ & 0.5 & I. $\mathrm{M}^{(\mathrm{c})}$ & 124.8 & 973 & 8 & ${ }^{(\mathrm{f})} 83$ & (i) 517 & [43] \\
\hline 20. & $40 \% \mathrm{Co}-6.3 \% \mathrm{Mo}$ & $\mathrm{Al}_{2} \mathrm{O}_{3}$ & 0.5 & I. M ${ }^{(c)}$ & 107.6 & 973 & 8 & (f) 84 & (i) 568 & [43] \\
\hline 21. & $20 \% \mathrm{Ni}-20 \% \mathrm{Co}$ & $\mathrm{Al}_{2} \mathrm{O}_{3}$ & 0.3 & I. $\mathrm{M}^{(\mathrm{c})}$ & 151 & 973 & 5 & ${ }^{(\mathrm{g})} 70$ & (i) 600 & [69] \\
\hline 22. & $22 \% \mathrm{Ni}-22 \% \mathrm{Co}$ & $\mathrm{Al}_{2} \mathrm{O}_{3}$ & 0.3 & I. M ${ }^{(c)}$ & 150 & 973 & 5 & ${ }^{(\mathrm{g})} 72$ & (i) 700 & [69] \\
\hline 23. & $25 \% \mathrm{Ni}-25 \% \mathrm{Co}$ & $\mathrm{Al}_{2} \mathrm{O}_{3}$ & 0.3 & I. M ${ }^{(c)}$ & 120 & 973 & 5 & (g) 74 & (i) 850 & [69] \\
\hline 24. & $27 \% \mathrm{Ni}-27 \% \mathrm{Co}$ & $\mathrm{Al}_{2} \mathrm{O}_{3}$ & 0.3 & I. M ${ }^{(c)}$ & 123 & 973 & 5 & (g) 73 & (i) 720 & [69] \\
\hline 25. & $30 \% \mathrm{Ni}-30 \% \mathrm{Co}$ & $\mathrm{Al}_{2} \mathrm{O}_{3}$ & 0.3 & I. M ${ }^{(c)}$ & 127 & 973 & 5 & (g) 70 & (i) 650 & [69] \\
\hline 26. & $25 \% \mathrm{Co}-25 \% \mathrm{Cr}$ & $\mathrm{MgO}$ & 0.5 & I. $\mathrm{M}^{(\mathrm{c})}$ & 39.8 & 973 & 7 & (g) 73 & (h) 1.6 & [45] \\
\hline 27. & $25 \% \mathrm{Co}-25 \% \mathrm{Mo}$ & $\mathrm{MgO}$ & 0.5 & I. M ${ }^{(c)}$ & 50.7 & 973 & 7 & (g) 81 & (h) 2.38 & [45] \\
\hline 28. & $25 \% \mathrm{Co}-25 \% \mathrm{~W}$ & $\mathrm{MgO}$ & 0.5 & I. M ${ }^{(c)}$ & 34.5 & 973 & 7 & (g) 76 & (h) 2.04 & [45] \\
\hline 29. & $40 \% \mathrm{Co}-10 \% \mathrm{~W}$ & $\mathrm{MgO}$ & 0.5 & I. M ${ }^{(c)}$ & 38.1 & 973 & 7 & (g) 85 & (i) 280 & [42] \\
\hline 30. & $30 \% \mathrm{Co}-20 \% \mathrm{~W}$ & $\mathrm{MgO}$ & 0.5 & I. M ${ }^{(c)}$ & 36.8 & 973 & 7 & (g) 73 & (i) 237 & [42] \\
\hline 31. & $20 \% \mathrm{Co}-30 \% \mathrm{~W}$ & $\mathrm{MgO}$ & 0.5 & I. M ${ }^{(c)}$ & 29.5 & 973 & 7 & ${ }^{(\mathrm{g})} 69$ & (i) 229 & [42] \\
\hline 32. & $10 \% \mathrm{Co}-40 \% \mathrm{~W}$ & $\mathrm{MgO}$ & 0.5 & I. M ${ }^{(c)}$ & 16.7 & 973 & 7 & $\left.{ }^{(\mathrm{g}}\right)_{20}$ & (i) 51 & [42] \\
\hline 33. & $25 \% \mathrm{Fe}-25 \% \mathrm{Co}$ & $\mathrm{MgO}$ & 0.5 & I. M ${ }^{(c)}$ & 52.7 & 973 & 7 & ${ }^{(\mathrm{f})} 82$ & (i) 340 & [48] \\
\hline 34. & $25 \% \mathrm{Ni}-25 \% \mathrm{Fe}$ & $\mathrm{MgO}$ & 0.5 & I. $\mathrm{M}^{(\mathrm{c})}$ & 68.2 & 973 & 7 & ${ }^{(\mathrm{f})} 16$ & (i) 411 & [48] \\
\hline 35. & $25 \% \mathrm{Ni}-25 \% \mathrm{Co}$ & $\mathrm{MgO}$ & 0.5 & I. M(c) & 24.1 & 973 & 7 & ${ }^{(\mathrm{f})} 13$ & (i) 766 & [48] \\
\hline
\end{tabular}




\begin{tabular}{|c|c|c|c|c|c|c|c|c|c|c|}
\hline S. No & Metal & Support & $\begin{array}{l}{ }^{(a)} \mathrm{Wc} \\
(\mathrm{g})\end{array}$ & Preparation & $\begin{array}{l}\text { S.A } \\
\mathrm{m}^{2} \mathrm{~g}^{-1}\end{array}$ & ${ }^{(\mathrm{d})} \mathrm{T}_{\mathrm{R}}(\mathrm{K})$ & $\begin{array}{l}\left({ }^{(e)} \mathrm{R}_{\mathrm{T}}\right. \\
\text { (h) }\end{array}$ & $\begin{array}{l}\text { Conversion/Yield } \\
(\%)\end{array}$ & Carbon & Ref \\
\hline 36. & $60 \% \mathrm{Ni}$ & $15 \% \mathrm{TiO}_{2}-\mathrm{Al}_{2} \mathrm{O}_{3}$ & 0.5 & $\mathrm{I}^{\mathrm{I}} \mathrm{M}^{(\mathrm{c})}$ & 94 & 973 & 7 & ${ }^{(\mathrm{f})} 25$ & (i) 126 & [38] \\
\hline 37. & $60 \% \mathrm{Ni}$ & $25 \% \mathrm{TiO}_{2}-\mathrm{Al}_{2} \mathrm{O}_{3}$ & 0.5 & I. $\mathrm{M}^{(\mathrm{c})}$ & 135 & 973 & 7 & (f) 60 & (i) 504 & [38] \\
\hline 38. & $60 \% \mathrm{Ni}$ & $50 \% \mathrm{TiO}_{2}-\mathrm{Al}_{2} \mathrm{O}_{3}$ & 0.5 & $\mathrm{I}^{\mathrm{I}} \mathrm{M}^{(\mathrm{c})}$ & 70 & 973 & 7 & (f) 65 & (i) 413 & [38] \\
\hline 39. & $\mathrm{Ni}-\mathrm{Pd}$ & $\mathrm{MgAl}_{2} \mathrm{O}_{4}$ & 1 & - & 29.38 & 973 & 5 & (f) 43 & - & [50] \\
\hline 40. & $\mathrm{Ni}-\mathrm{Co}$ & SBA-15 & 3 & I. $\mathrm{M}^{(\mathrm{c})}$ & 312.0 & 973 & 5 & (f) 44 & (i) 257 & [47] \\
\hline 41. & $\mathrm{Ni}-\mathrm{Fe}$ & SBA-15 & 3 & I. $\mathrm{M}^{(\mathrm{c})}$ & 294.0 & 973 & 5 & (f) 41 & (i) 233 & [47] \\
\hline 42. & $\mathrm{Co}-\mathrm{Fe}$ & SBA-15 & 3 & I. $\mathrm{M}^{(\mathrm{c})}$ & 286.0 & 973 & 5 & (f) 46 & (i) 233 & [47] \\
\hline 43. & $50 \% \mathrm{Ni}-0.2 \% \mathrm{Pd}$ & SBA-15 & 1 & I. $\mathrm{M}^{(\mathrm{c})}$ & 198.2 & 973 & 7 & (f) 45 & (i) 489 & [49] \\
\hline 44. & $50 \% \mathrm{Ni}-0.4 \% \mathrm{Pd}$ & SBA-15 & 1 & I. $\mathrm{M}^{(\mathrm{c})}$ & 201.8 & 973 & 7 & (f) 50 & (i) 489 & [49] \\
\hline 45. & $12.5 \% \mathrm{Ni}-12.5 \% \mathrm{Co}$ & $\mathrm{La}_{2} \mathrm{O}_{3}$ & 0.3 & I. $\mathrm{M}^{(\mathrm{c})}$ & 63.3 & 973 & 5 & (f) 77 & - & [72] \\
\hline 46. & $50 \% \mathrm{Ni}-5 \% \mathrm{Fe}$ & $\mathrm{Al}_{2} \mathrm{O}_{3}$ & 0.05 & $\mathrm{I}^{\mathrm{M}} \mathrm{M}^{(\mathrm{c})}$ & 83.7 & 948 & 11 & (g) 35 & - & [77] \\
\hline 47. & $50 \% \mathrm{Ni}-10 \% \mathrm{Fe}$ & $\mathrm{Al}_{2} \mathrm{O}_{3}$ & 0.05 & I. $\mathrm{M}^{(\mathrm{c})}$ & 78.8 & 948 & 11 & ${ }^{(\mathrm{g})} 70$ & - & [77] \\
\hline 48. & $50 \% \mathrm{Ni}-15 \% \mathrm{Fe}$ & $\mathrm{Al}_{2} \mathrm{O}_{3}$ & 0.05 & I. $\mathrm{M}^{(\mathrm{c})}$ & 74.8 & 948 & 11 & ${ }^{(\mathrm{g})} 68$ & - & [77] \\
\hline 49. & $7.39 \% \mathrm{Ni}-7.28 \% \mathrm{Co}$ & $\mathrm{La}_{2} \mathrm{O}_{3}$ & 0.3 & I. $\mathrm{M}^{(\mathrm{c})}$ & 30.19 & 973 & 5 & ${ }^{(\mathrm{g})} 70$ & (i) 20 & [71] \\
\hline 50. & $9.81 \% \mathrm{Ni}-9.72 \% \mathrm{Co}$ & $\mathrm{La}_{2} \mathrm{O}_{3}$ & 0.3 & I. $\mathrm{M}^{(\mathrm{c})}$ & 61.64 & 973 & 5 & $(\mathrm{~g}) 79$ & (i) 50 & [71] \\
\hline 51. & $11.32 \% \mathrm{Ni}-12.11 \% \mathrm{Co}$ & $\mathrm{La}_{2} \mathrm{O}_{3}$ & 0.3 & I. $\mathrm{M}^{(\mathrm{c})}$ & 63.32 & 973 & 5 & ${ }^{(\mathrm{g})} 80$ & (i) 90 & [71] \\
\hline 52. & $14.75 \% \mathrm{Ni}-13.92 \% \mathrm{Co}$ & $\mathrm{La}_{2} \mathrm{O}_{3}$ & 0.3 & I. $\mathrm{M}^{(\mathrm{c})}$ & 56.02 & 973 & 5 & $(\mathrm{~g}) 79$ & (i) 60 & [71] \\
\hline 53. & $18.85 \% \mathrm{Ni}-19.63 \% \mathrm{Co}$ & $\mathrm{La}_{2} \mathrm{O}_{3}$ & 0.3 & I. $\mathrm{M}^{(\mathrm{c})}$ & 48.45 & 973 & 5 & ${ }^{(\mathrm{g})} 78$ & (i) 35 & [71] \\
\hline 54. & $\mathrm{Ni}-\mathrm{Pd}$ & $\mathrm{Al}_{2} \mathrm{O}_{3}$ & - & I. $\mathrm{M}^{(\mathrm{c})}$ & 212.80 & 1073 & 4 & (g) 40 & - & [55] \\
\hline 55. & $65 \% \mathrm{Ni}-10 \% \mathrm{Cu}$ & $\mathrm{SiO}_{2}$ & - & - & 37.70 & 923 & 6 & (g) 43 & & [82] \\
\hline
\end{tabular}




\begin{tabular}{|c|c|c|c|c|c|c|c|c|c|c|}
\hline S. No & Metal & Support & $\begin{array}{l}\left({ }^{(a)} \mathrm{Wc}\right. \\
(\mathrm{g})\end{array}$ & Preparation & $\begin{array}{l}\text { S.A } \\
m^{2} g^{-1}\end{array}$ & ${ }^{(\mathrm{d})} \mathrm{T}_{\mathrm{R}}(\mathrm{K})$ & $\begin{array}{l}{ }^{(\mathrm{e})} \mathrm{R}_{\mathrm{T}} \\
\text { (h) }\end{array}$ & $\begin{array}{l}\text { Conversion/Yield } \\
(\%)\end{array}$ & Carbon & Ref \\
\hline 56. & $50 \% \mathrm{Ni}-20 \% \mathrm{Cu}$ & $\mathrm{SiO}_{2}$ & - & - & 27.83 & 923 & 6 & ${ }^{(\mathrm{g})} 27$ & - & [82] \\
\hline 57. & $5 \% \mathrm{Ni}-\mathrm{Cu}$ & $\mathrm{Al}_{2} \mathrm{O}_{3}$ & 2.5 & I. $\mathrm{M}^{(\mathrm{c})}$ & 63.80 & 1123 & 4 & (f) 40 & - & [83] \\
\hline 58. & $10 \% \mathrm{Ni}-\mathrm{Cu}$ & $\mathrm{Al}_{2} \mathrm{O}_{3}$ & 2.5 & I.M $\mathrm{M}^{(\mathrm{c})}$ & 84.10 & 1123 & 4 & (f) 58 & - & [83] \\
\hline 59. & $15 \% \mathrm{Ni}-\mathrm{Cu}$ & $\mathrm{Al}_{2} \mathrm{O}_{3}$ & 2.5 & I. $\mathrm{M}^{(\mathrm{c})}$ & 42.60 & 1123 & 4 & (f) 52 & - & [83] \\
\hline 60. & $20 \% \mathrm{Ni}-\mathrm{Cu}$ & $\mathrm{Al}_{2} \mathrm{O}_{3}$ & 2.5 & I. $\mathrm{M}^{(\mathrm{c})}$ & 34.30 & 1123 & 4 & ${ }^{(\mathrm{f})} 37$ & - & [83] \\
\hline 61. & $50 \% \mathrm{Ni}-5 \% \mathrm{Pd}$ & $\mathrm{Al}_{2} \mathrm{O}_{3}$ & 0.05 & I. M ${ }^{(\mathrm{c})}$ & 72.75 & 1023 & 10 & (g) 65 & (i) 360 & [76] \\
\hline 62. & $50 \% \mathrm{Ni}-10 \% \mathrm{Pd}$ & $\mathrm{Al}_{2} \mathrm{O}_{3}$ & 0.05 & I. $\mathrm{M}^{(\mathrm{c})}$ & 45.81 & 1023 & 10 & ${ }^{(\mathrm{g})} 72$ & (j) 380 & [76] \\
\hline 63. & $50 \% \mathrm{Ni}-15 \% \mathrm{Pd}$ & $\mathrm{Al}_{2} \mathrm{O}_{3}$ & 0.05 & I. $\mathrm{M}^{(\mathrm{c})}$ & 26.91 & 1023 & 10 & (g) 81 & (j) 400 & [76] \\
\hline 64. & $50 \% \mathrm{Ni}-20 \% \mathrm{Pd}$ & $\mathrm{Al}_{2} \mathrm{O}_{3}$ & 0.05 & I. $\mathrm{M}^{(\mathrm{c})}$ & 12.36 & 1023 & 10 & ${ }^{(\mathrm{g})} 76$ & ${ }^{(j} 410$ & [76] \\
\hline 65. & $30 \% \mathrm{Fe}-6 \% \mathrm{Ce}$ & $\mathrm{Al}_{2} \mathrm{O}_{3}$ & - & I. $\mathrm{M}^{(\mathrm{c})}$ & 56.25 & 973 & 3 & ${ }^{(\mathrm{f})} 66$ & - & [68] \\
\hline 66. & $30 \% \mathrm{Fe}-15 \% \mathrm{Ce}$ & $\mathrm{Al}_{2} \mathrm{O}_{3}$ & - & $\mathrm{I}^{\mathrm{I}} \mathrm{M}^{(\mathrm{c})}$ & 52.1 & 973 & 3 & (f) 62 & - & [68] \\
\hline 67. & $30 \% \mathrm{Fe}-30 \% \mathrm{Ce}$ & $\mathrm{Al}_{2} \mathrm{O}_{3}$ & - & I. $\mathrm{M}^{(\mathrm{c})}$ & 95.3 & 973 & 3 & (f) 54 & - & [68] \\
\hline 68. & $50 \% \mathrm{Ni}-5 \% \mathrm{Cu}$ & $\mathrm{Al}_{2} \mathrm{O}_{3}$ & 0.05 & $\mathrm{I}^{\mathrm{I}} \mathrm{M}^{(\mathrm{c})}$ & 72.25 & 1023 & 11 & (g) 20 & - & [73] \\
\hline 69. & $50 \% \mathrm{Ni}-10 \% \mathrm{Cu}$ & $\mathrm{Al}_{2} \mathrm{O}_{3}$ & 0.05 & I. $\mathrm{M}^{(\mathrm{c})}$ & 70.34 & 1023 & 11 & (g) 79 & - & [73] \\
\hline 70. & $50 \% \mathrm{Ni}-15 \% \mathrm{Cu}$ & $\mathrm{Al}_{2} \mathrm{O}_{3}$ & 0.05 & I. $\mathrm{M}^{(\mathrm{c})}$ & 51.89 & 1023 & 11 & (g) 84 & - & [73] \\
\hline 71. & $30 \% \mathrm{Fe}-15 \% \mathrm{Ni}$ & $\mathrm{Al}_{2} \mathrm{O}_{3}$ & 0.3 & I. $\mathrm{M}^{(\mathrm{c})}$ & 132.5 & 973 & 3 & (g) 73 & - & [53] \\
\hline 72. & $30 \% \mathrm{Fe}-15 \% \mathrm{Co}$ & $\mathrm{Al}_{2} \mathrm{O}_{3}$ & 0.3 & I. $\mathrm{M}^{(\mathrm{c})}$ & 133.6 & 973 & 3 & (g) 74 & (h) 15 & [53] \\
\hline 73. & $5 \% \mathrm{Ni}-20 \% \mathrm{Fe}$ & $\mathrm{Al}_{2} \mathrm{O}_{3}$ & 0.3 & I. M ${ }^{(\mathrm{c})}$ & 147.7 & 973 & 3 & ${ }^{(\mathrm{g})} 65$ & - & [70] \\
\hline 74. & $10 \% \mathrm{Ni}-20 \% \mathrm{Fe}$ & $\mathrm{Al}_{2} \mathrm{O}_{3}$ & 0.3 & I. $\mathrm{M}^{(\mathrm{c})}$ & 140.6 & 973 & 3 & ${ }^{(\mathrm{g})} 66$ & - & [70] \\
\hline 75. & $30 \% \mathrm{Fe}-6 \% \mathrm{Co}$ & $\mathrm{Al}_{2} \mathrm{O}_{3}$ & 0.3 & I.M ${ }^{(c)}$ & 43.4 & 973 & 3 & ${ }^{(\mathrm{g})} 66$ & - & [29] \\
\hline
\end{tabular}




\begin{tabular}{|c|c|c|c|c|c|c|c|c|c|c|}
\hline S. No & Metal & Support & $\begin{array}{l}(\mathrm{a}) \mathrm{Wc} \\
\text { (g) }\end{array}$ & Preparation & $\begin{array}{l}\text { S.A } \\
\mathrm{m}^{2} \mathrm{~g}^{-1}\end{array}$ & ${ }^{(\mathrm{d})} \mathrm{T}_{\mathrm{R}}(\mathrm{K})$ & $\begin{array}{l}{ }^{(e)} \mathrm{R}_{\mathrm{T}} \\
\text { (h) }\end{array}$ & $\begin{array}{l}\text { Conversion/Yield } \\
(\%)\end{array}$ & Carbon & Ref \\
\hline 76. & $30 \% \mathrm{Fe}-15 \% \mathrm{Co}$ & $\mathrm{Al}_{2} \mathrm{O}_{3}$ & 0.3 & I. $\mathrm{M}^{(\mathrm{c})}$ & 52.4 & 973 & 3 & ${ }^{(\mathrm{g})} 74$ & - & [29] \\
\hline 77. & $30 \% \mathrm{Fe}-30 \% \mathrm{Co}$ & $\mathrm{Al}_{2} \mathrm{O}_{3}$ & 0.3 & I.M ${ }^{(\mathrm{c})}$ & 72 & 973 & 3 & (g) 71 & - & [29] \\
\hline 78. & $50 \% \mathrm{Ni}$ & $25 \% \mathrm{CeO}_{2}-75 \% \mathrm{Al}_{2} \mathrm{O}_{3}$ & 0.5 & I. $\mathrm{M}^{(\mathrm{c})}$ & 34 & 973 & 6 & ${ }^{(\mathrm{f})} 52$ & - & [66] \\
\hline 79. & $50 \% \mathrm{Ni}$ & $50 \% \mathrm{CeO}_{2}-50 \% \mathrm{Al}_{2} \mathrm{O}_{3}$ & 0.5 & I.M ${ }^{(\mathrm{c})}$ & 51 & 973 & 6 & (f) 40 & - & [66] \\
\hline 80. & $50 \% \mathrm{Ni}$ & $75 \% \mathrm{CeO}_{2}-25 \% \mathrm{Al}_{2} \mathrm{O}_{3}$ & 0.5 & I. $\mathrm{M}^{(\mathrm{c})}$ & 69 & 973 & 6 & (f) 42 & - & [66] \\
\hline 81. & $15 \% \mathrm{Fe}-6 \% \mathrm{Ni}$ & $\mathrm{MgO}$ & 0.3 & I. $\mathrm{M}^{(\mathrm{c})}$ & 100 & 973 & 3 & ${ }^{(\mathrm{g})} 66$ & (h) 16.26 & [67] \\
\hline 82. & $15 \% \mathrm{Fe}-6 \% \mathrm{Co}$ & $\mathrm{MgO}$ & 0.3 & I.M ${ }^{(c)}$ & 86 & 973 & 3 & ${ }^{(\mathrm{g})} 69$ & (h) 15.06 & [67] \\
\hline 83. & $15 \% \mathrm{Fe}-6 \% \mathrm{Mn}$ & $\mathrm{MgO}$ & 0.3 & I. $M^{(c)}$ & 122 & 973 & 3 & (g) 68 & (h) 15.49 & [67] \\
\hline 84. & $5 \% \mathrm{Fe}-1 \% \mathrm{Mo}$ & $\mathrm{MgO}$ & 0.5 & I. $M^{(c)}$ & 90 & 1173 & - & - & (i) 32.3 & [57] \\
\hline 85. & $5 \% \mathrm{Fe}-1 \% \mathrm{Cu}$ & $\mathrm{MgO}$ & 0.5 & I. $M^{(c)}$ & 54 & 1173 & - & - & (i) 5.8 & [57] \\
\hline 86. & $50 \% \mathrm{Ni}$ & $\mathrm{SiO}_{2}-\mathrm{Al}_{2} \mathrm{O}_{3}$ & 0.5 & I. $\mathrm{M}^{(\mathrm{c})}$ & 107 & 973 & 3 & (f) 60 & - & [84] \\
\hline 87. & $50 \% \mathrm{Ni}$ & $\mathrm{SiO}_{2}-\mathrm{CeO}_{2}$ & 0.5 & I. $M^{(c)}$ & 37 & 973 & 3 & (f) 55 & - & [84] \\
\hline 88. & $50 \% \mathrm{Ni}$ & $\mathrm{SiO}_{2}-\mathrm{La}_{2} \mathrm{O}_{3}$ & 0.5 & I. $M^{(c)}$ & 44 & 973 & 3 & (f) 58 & - & [84] \\
\hline 89. & $50 \% \mathrm{Ni}$ & $\mathrm{SiO}_{2}-\mathrm{MgO}$ & 0.5 & I. $M^{(c)}$ & 54 & 973 & 3 & (f) 13 & - & [84] \\
\hline 90. & $55 \% \mathrm{Ni}$ & $\mathrm{MgO}-\mathrm{Al}_{2} \mathrm{O}_{3}$ & 0.025 & - & 66.31 & 948 & 5 & (g) 8 & ${ }^{\mathrm{i}} 140$ & [80] \\
\hline 91. & $55 \% \mathrm{Ni}-10 \% \mathrm{Ce}$ & $\mathrm{MgO}-\mathrm{Al}_{2} \mathrm{O}_{3}$ & 0.025 & - & 55.06 & 948 & 5 & (g) 12 & ${ }^{\mathrm{i}} 150$ & [80] \\
\hline 92. & $55 \% \mathrm{Ni}-10 \% \mathrm{Co}$ & $\mathrm{MgO}-\mathrm{Al}_{2} \mathrm{O}_{3}$ & 0.025 & - & 46.84 & 948 & 5 & ${ }^{(\mathrm{g})} 12$ & ${ }^{\mathrm{i}} 120$ & [80] \\
\hline 93. & $55 \% \mathrm{Ni}-10 \% \mathrm{Cu}$ & $\mathrm{MgO}-\mathrm{Al}_{2} \mathrm{O}_{3}$ & 0.025 & - & 43.57 & 948 & 5 & ${ }^{(\mathrm{g})} 10$ & $\mathrm{i}_{2} 280$ & [80] \\
\hline 94. & $55 \% \mathrm{Ni}-10 \% \mathrm{Fe}$ & $\mathrm{MgO}-\mathrm{Al}_{2} \mathrm{O}_{3}$ & 0.025 & - & 66.18 & 948 & 5 & ${ }^{(\mathrm{g})} 13$ & ${ }^{\mathrm{i}} 100$ & [80] \\
\hline 95. & $55 \% \mathrm{Ni}-10 \% \mathrm{La}$ & $\mathrm{MgO}-\mathrm{Al}_{2} \mathrm{O}_{3}$ & 0.025 & - & 41.86 & 948 & 5 & ${ }^{(\mathrm{g})} 11$ & ${ }^{\mathrm{j}} 120$ & [80] \\
\hline
\end{tabular}




\begin{tabular}{|c|c|c|c|c|c|c|c|c|c|c|}
\hline S. No & Metal & Support & $\begin{array}{l}(\mathrm{a}) \mathrm{Wc} \\
(\mathrm{g})\end{array}$ & Preparation & $\begin{array}{l}\text { S.A } \\
\mathrm{m}^{2} \mathrm{~g}^{-1}\end{array}$ & ${ }^{(\mathrm{d})} \mathrm{T}_{\mathrm{R}}(\mathrm{K})$ & $\begin{array}{l}{ }^{(e)} R_{\mathrm{T}} \\
\text { (h) }\end{array}$ & $\begin{array}{l}\text { Conversion/Yield } \\
(\%)\end{array}$ & Carbon & Ref \\
\hline 96. & $10 \% \mathrm{Ni}$ & $0.5 \% \mathrm{MgO}-\mathrm{Al}_{2} \mathrm{O}_{3}$ & 0.025 & - & 236.0 & 973 & 5 & ${ }^{(\mathrm{f})} 05$ & - & [79] \\
\hline 97. & $10 \% \mathrm{Ni}$ & $1.0 \% \mathrm{MgO}-\mathrm{Al}_{2} \mathrm{O}_{3}$ & 0.025 & - & 224.0 & 973 & 5 & ${ }^{(\mathrm{f})} 06$ & - & [79] \\
\hline 98. & $10 \% \mathrm{Ni}$ & $1.5 \% \mathrm{MgO}-\mathrm{Al}_{2} \mathrm{O}_{3}$ & 0.025 & - & 216.0 & 973 & 5 & ${ }^{(\mathrm{f})} 08$ & - & [79] \\
\hline 99. & $10 \% \mathrm{Ni}$ & $2.0 \% \mathrm{MgO}-\mathrm{Al}_{2} \mathrm{O}_{3}$ & 0.025 & - & 220.0 & 898 & 5 & ${ }^{(\mathrm{g})} 04$ & - & [79] \\
\hline 100. & $25 \% \mathrm{Ni}$ & $2.0 \% \mathrm{MgO}-\mathrm{Al}_{2} \mathrm{O}_{3}$ & 0.025 & - & 149 & 898 & 5 & (g) 05 & - & [79] \\
\hline 101. & $40 \% \mathrm{Ni}$ & $2.0 \% \mathrm{MgO}-\mathrm{Al}_{2} \mathrm{O}_{3}$ & 0.025 & - & 105 & 898 & 5 & (g) 13 & - & [79] \\
\hline 102. & $55 \% \mathrm{Ni}$ & $2.0 \% \mathrm{MgO}-\mathrm{Al}_{2} \mathrm{O}_{3}$ & 0.025 & - & 66 & 898 & 5 & ${ }^{(\mathrm{g})} 20$ & - & [79] \\
\hline 103. & $6 \% \mathrm{Ni}-30 \% \mathrm{Fe}$ & $\mathrm{Al}_{2} \mathrm{O}_{3}$ & 0.3 & $\mathrm{I} . \mathrm{M}^{(\mathrm{c})}$ & 135.5 & 973 & 3 & ${ }^{(\mathrm{g})} 61$ & - & [85] \\
\hline 104. & $15 \% \mathrm{Ni}-30 \% \mathrm{Fe}$ & $\mathrm{Al}_{2} \mathrm{O}_{3}$ & 0.3 & I. $\mathrm{M}^{(\mathrm{c})}$ & 132.5 & 973 & 3 & ${ }^{(\mathrm{g})} 62$ & - & [85] \\
\hline 105. & $30 \% \mathrm{Ni}-30 \% \mathrm{Fe}$ & $\mathrm{Al}_{2} \mathrm{O}_{3}$ & 0.3 & I. $\mathrm{M}^{(\mathrm{c})}$ & 130.0 & 973 & 3 & ${ }^{(\mathrm{g})} 56$ & - & [85] \\
\hline 106. & $6 \% \mathrm{Mn}-30 \% \mathrm{Fe}$ & $\mathrm{Al}_{2} \mathrm{O}_{3}$ & 0.3 & I. $\mathrm{M}^{(\mathrm{c})}$ & 143.9 & 973 & 3 & (g) 11 & - & [85] \\
\hline 107. & $15 \% \mathrm{Mn}-30 \% \mathrm{Fe}$ & $\mathrm{Al}_{2} \mathrm{O}_{3}$ & 0.3 & $\mathrm{I}^{\mathrm{M}} \mathrm{M}^{(\mathrm{c})}$ & 131.1 & 973 & 3 & (g) 10 & - & [85] \\
\hline 108. & $30 \% \mathrm{Mn}-30 \% \mathrm{Fe}$ & $\mathrm{Al}_{2} \mathrm{O}_{3}$ & 0.3 & $\mathrm{I}^{\mathrm{M}} \mathrm{M}^{(\mathrm{c})}$ & 123.8 & 973 & 3 & (g) 13 & - & [85] \\
\hline
\end{tabular}

(a)Weight of catalyst (b) Fusion method (c) Impregnation method (d) Reaction temperature (e) Reaction Time (f) $\mathrm{H}_{2}$ yield (g) Methane (h) g c/ g ni (i) \% (J) mg 


\subsection{Tri-metallic Catalyst}

Sections 2.1 and 2.2 summarized various contributions relevant to this study. Moreover, the effects of monometallic and bimetallic have been explained in Tables 1 and 2 respectively. Although the $\mathrm{CH}_{4}$ yields were improved with higher metal loadings and shifting from mono metallic to bimetallic due to alloying effect, some of the scholars tried to further optimize the process by taking into account the effectiveness of commissioning trimetallic catalyst for $\mathrm{CO}_{\mathrm{X}}$ free $\mathrm{H}_{2}$ production $[86,87]$.

Kumar et al. [88, 89] synthesized different compositions of $\mathrm{Ni}-\mathrm{Cu}-\mathrm{Zn} / \mathrm{MCM} 22$. The catalytic stability was widely explored over reaction temperature, metal loadings, and GHSV. It was depicted that the combination of $\mathrm{Cu}$ and $\mathrm{Zn}$ enhanced the $\mathrm{CH}_{4}$ conversions and $\mathrm{H}_{2}$ yields. Interestingly, the carbon yield also increased by incrementing the loadings of $\mathrm{Cu}$ and $\mathrm{Zn}$ which proved that the carbon diffusion rate of the promoted catalyst was improved as compared to the un-promoted Ni-based catalyst. This suggests that bimetallic promoters are more active catalysts as compared to monometallic promoters. Pure $\mathrm{H}_{2}$ and unreacted $\mathrm{CH}_{4}$ were the only gaseous products detected by gas chromatography, whereas TEM analysis confirmed the formation of MWCNT as by-product deposited on the surface of the catalyst.

Bayat et al. [90] worked on $\mathrm{Fe}-\mathrm{Cu}$ promoted $\mathrm{Ni} / \mathrm{Al}_{2} \mathrm{O}_{3}$ catalyst. The addition of $\mathrm{Fe}$ and $\mathrm{Cu}$ in the metallic catalyst amended the catalytic stability. The promoting effect enhanced the carbon diffusion rates and hindered the formation of encapsulated carbon over the active sites. Moreover, the degree of reducibility and the dispersion of $\mathrm{NiO}$ on the support was also improved. The performance evaluation of the catalyst revealed that bi-promoted catalyst performed well at higher reaction temperatures. Similar results were also reported in [91] where the authors mentioned that the modification of Ni-based catalyst with $\mathrm{Fe}$ and $\mathrm{Cu}$ made it possible to carry the TCD reactions 
above $973 \mathrm{~K}$ without affecting the physiochemical properties and stability of the materials. The effects of impregnating $\mathrm{Ni}$ and $\mathrm{Co}$ on Fe based catalyst was also studied [53] in detail, and both $\mathrm{CH}_{4}$ conversions and stability of the catalyst were increased. Catalytic activity and stability of various trimetallic catalyst having different supporters and reaction conditions in FBR in TCD have been summarized in Table 3 .

It can be concluded from the forementioned discussion that Ni-based catalysts are frequently used in reforming reactions due to their low cost, easy availability and highly reactive nature. The applications of these catalysts are also evident in the thermocatalytic decomposition of methane, but the only limitation that restricts industrial usage is its fast deactivation due to encapsulation of low active carbon produced as a by-product. The reaction rate of TCD is very high due to highly active nature of $\mathrm{Ni}$, and hence ample amount of carbon is produced but the low diffusion rate of carbon in $\mathrm{Ni}$ forces the material to lose its catalytic stability and activity shortly. Hence, the impregnation of monometallic and bimetallic promoters on the Ni-based catalyst is proposed to be an active solution to this issue as explained in Sections 2.2 and 2.3 respectively. 
Table 3: Catalytic activity and stability of various trimetallic catalysts having different supporters and reaction conditions in FBR in TCD

\begin{tabular}{|c|c|c|c|c|c|c|c|c|c|c|}
\hline $\begin{array}{l}\text { S. } \\
\text { No }\end{array}$ & Metal & Support & ${ }^{(a)} \mathrm{Wc}(\mathrm{g})$ & Preparation & S.A m ${ }^{2} \mathrm{~g}^{-1}$ & ${ }^{(\mathrm{d})} \mathrm{T}_{\mathrm{R}}(\mathrm{K})$ & ${ }^{(\mathrm{e})} \mathrm{R}_{\mathrm{T}}(\mathrm{h})$ & $\begin{array}{l}\text { Conversion/Yield } \\
(\%)\end{array}$ & Carbon & Ref \\
\hline 1. & $50 \% \mathrm{Ni}-5 \% \mathrm{Cu}-5 \% \mathrm{Zn}$ & MCM-22 & 1 & $\mathrm{I}^{\mathrm{M}} \mathrm{M}^{(\mathrm{c})}$ & 19 & 1023 & - & $(\mathrm{g}) 84$ & (i) 900 & [88] \\
\hline 3. & $50 \% \mathrm{Ni}-15 \% \mathrm{Cu}-5 \% \mathrm{Zn}$ & MCM-22 & 1 & - & 14 & 1023 & - & (g) 80 & - & [89] \\
\hline 4. & $50 \% \mathrm{Ni}-5 \% \mathrm{Cu}-15 \% \mathrm{Zn}$ & MCM-22 & 1 & - & 12 & 1023 & - & (g) 70 & - & [89] \\
\hline 6. & $30 \% \mathrm{Fe}-5 \% \mathrm{Ni}-10 \% \mathrm{Co}$ & $\mathrm{Al}_{2} \mathrm{O}_{3}$ & 0.3 & I.M $\mathbf{M}^{(\mathrm{c})}$ & 131.1 & 973 & 3 & (g) 67 & - & [53] \\
\hline 7. & $30 \% \mathrm{Fe}-7.5 \% \mathrm{Ni}-7.5 \% \mathrm{Co}$ & $\mathrm{Al}_{2} \mathrm{O}_{3}$ & 0.3 & I.M $\mathbf{M}^{(\mathrm{c})}$ & 142.2 & 973 & 3 & (g) 68 & - & [53] \\
\hline 8. & $30 \% \mathrm{Fe}-10 \% \mathrm{Ni}-5 \% \mathrm{Co}$ & $\mathrm{Al}_{2} \mathrm{O}_{3}$ & 0.3 & I.M $^{(\mathrm{c})}$ & 138.4 & 973 & 3 & (g) 70 & - & [53] \\
\hline 9. & $50 \% \mathrm{Ni}-10 \% \mathrm{Fe}-5 \% \mathrm{Cu}$ & $\mathrm{Al}_{2} \mathrm{O}_{3}$ & 0.05 & I.M $^{(\mathrm{c})}$ & 73.3 & 1023 & 10 & (g) 70 & - & [90] \\
\hline 10. & $50 \% \mathrm{Ni}-10 \% \mathrm{Fe}-10 \% \mathrm{Cu}$ & $\mathrm{Al}_{2} \mathrm{O}_{3}$ & 0.05 & I.M $\mathbf{M}^{(\mathrm{c})}$ & 59.7 & 1023 & 10 & (g) 81 & - & [90] \\
\hline 11. & $50 \% \mathrm{Ni}-10 \% \mathrm{Fe}-15 \% \mathrm{Cu}$ & $\mathrm{Al}_{2} \mathrm{O}_{3}$ & 0.05 & I.M $\mathbf{M}^{(\mathrm{c})}$ & 51.0 & 1023 & 10 & (g) 82 & - & [90] \\
\hline 12. & $\mathrm{Fe}-\mathrm{Mo}-\mathrm{Cu}$ & $\mathrm{MgO}$ & 0.5 & $\mathrm{I} \mathrm{M}^{(\mathrm{c})}$ & 67 & 1173 & - & - & (i) 14.2 & [57] \\
\hline
\end{tabular}

(a)Weight of catalyst (b) Fusion method (c) Impregnation method (d) Reaction temperature (e) Reaction Time (f) $\mathrm{H}_{2}$ yield (g) Methane (h) g c/ g Ni (i) \% (J) $\mathrm{mg}$ 


\section{TCD Parameters}

TCD of $\mathrm{CH}_{4}$ is an endothermic process that is strongly affected by the reaction parameters, i.e. reaction temperature, GHSV, and metal loadings. It is also proposed that the morphology of the carbon deposited on the surface of the catalyst also depend upon the reaction parameters [24]. Therefore, to obtain higher $\mathrm{CH}_{4}$ conversions and increase the catalyst deactivation time, it is mandatory to have an optimum set of conditions. The individual impact of independent factors of $\mathrm{CH}_{4}$ decomposition has been discussed in subsequent sections.

\subsection{Reaction Temperature}

The reaction temperature has a very significant role in the $\mathrm{CH}_{4}$ conversions and catalyst stability. It is well understood that the product formation increases with the reaction temperatures due to the endothermic nature of the reaction, but the catalyst stability is affected due to the deposition of high amounts of carbon produced as a result of fast reaction rates [92].

The $\mathrm{CH}_{4}$ cracking reaction by using $\mathrm{Ni}$ supported on $\mathrm{SiO}_{2}, \mathrm{Al}_{2} \mathrm{O}_{3}, \mathrm{MgO}$, and $\mathrm{ZrO}_{2}$ was studied by Ermakova et al. [93]. The high catalytic stability was attained at temperatures ranges of $773-823$ $\mathrm{K}$, but at a higher temperature $(873 \mathrm{~K})$, the conversions dropped rapidly. It was reported that at $873 \mathrm{~K}$ the rate of carbon formation as a by-product was higher than the rate of carbon diffusion. Therefore, it grew on the active sites of the catalyst resulting in their early deactivation. In another work done by Martins et al. [94], the effects of reaction temperature over $\mathrm{Ni}-\mathrm{Cu} / \mathrm{SiO}_{2}$ were studied. The catalyst gave uniform conversions at $773 \mathrm{~K}$, but the conversion declined when TCD was carried out at a temperature higher than $873 \mathrm{~K}$. The possible reason for the loss in activity was found to be the sintering and encapsulation of carbon on the active sites. The effect of reaction temperature was also explored by Pinilla et al. [39]. The study was done on $\mathrm{Fe}-\mathrm{Mo} / \mathrm{MgO}$. The results were consistent with the above discussion as the initial $\mathrm{H}_{2}$ yields were increased with 
reaction temperature, but with time on stream (TOS) the yields dropped. The principal reason attributed to this observation was the high reaction rate at mounted temperatures which produces ample amount of carbon. This carbon is deposited over the surface of the catalyst instead of diffusing. Moreover, at higher reaction temperatures the catalyst loses its morphology due to sintering. The $\mathrm{H}_{2}$ yield at different reaction temperatures has been depicted in Fig 2 .

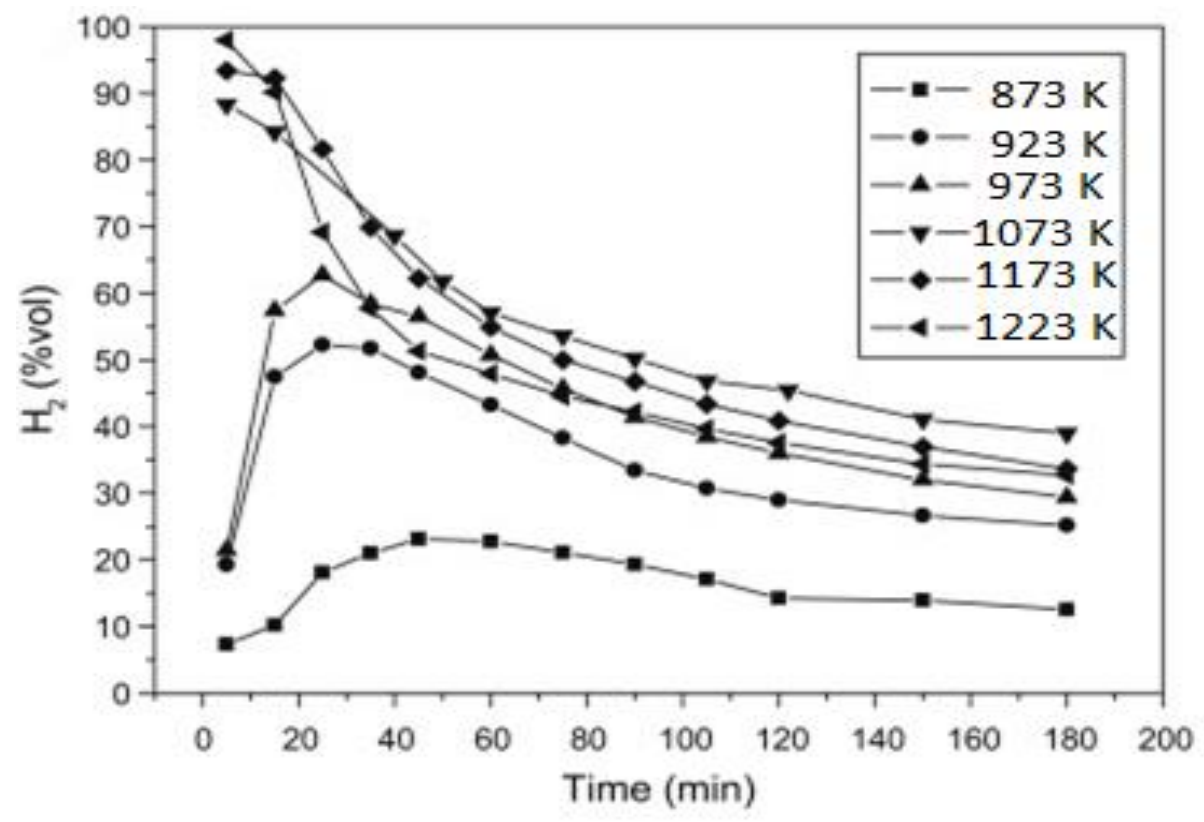

Fig 2: Influence of reaction temperature on $\mathrm{H}_{2}$ yield over $\mathrm{Fe}-\mathrm{Mo} / \mathrm{MgO}$; Reproduced with permission from Pinilla, Copyright 2011 Elsevier [39]

\subsection{Gas Hour Space Velocity}

The $\mathrm{CH}_{4}$ conversions are also strongly affected by GHSV. Kumar et al. [75] studied the effect of GHSV over various catalysts. Author conducted a series of experiments to elaborate the effect of GHSV (600-3000 $\left.\mathrm{mL} \mathrm{h}^{-1} \mathrm{~g}_{\mathrm{cat}}^{-1}\right)$ at $1023 \mathrm{~K}$. The highest activity of the catalyst $50 \% \mathrm{Ni}-\mathrm{xCu} / \mathrm{SiO}_{2}$ $(\mathrm{x}=0 \%, 5 \%$, and $10 \%)$ was observed at lowest GHSV, i.e. $600 \mathrm{~mL} \mathrm{~h}^{-1} \mathrm{~g}_{\mathrm{cat}}{ }^{-1}$. As the GHSV was increased, the $\mathrm{CH}_{4}$ conversions and carbon yields dropped because of relatively less diffusion time available to feedstock on the active sites of the catalyst as shown in Fig 3. It was concluded that sufficient contact time of $\mathrm{CH}_{4}$ with the catalyst at lower GHSV was the driving factor that resulted 
in better performance. Additionally, at higher flow rates the carbon depositions are high that damage the active sites of the catalyst. To optimize the process, the flow rate should be in optimum range to provide adequate contact time to the feedstocks and to promote equilibrium between the amounts of carbon formed and diffused. Similar results were also published by Bayat et al. [73] over $50 \% \mathrm{Ni}-10 \% \mathrm{Cu} / \mathrm{Al}_{2} \mathrm{O}_{3}$ at $\mathrm{GHSV}\left(10,000-50,000 \mathrm{~mL} \mathrm{~h}^{-1} \mathrm{~g}_{\mathrm{cat}}{ }^{-1}\right)$ at $948 \mathrm{~K}$.

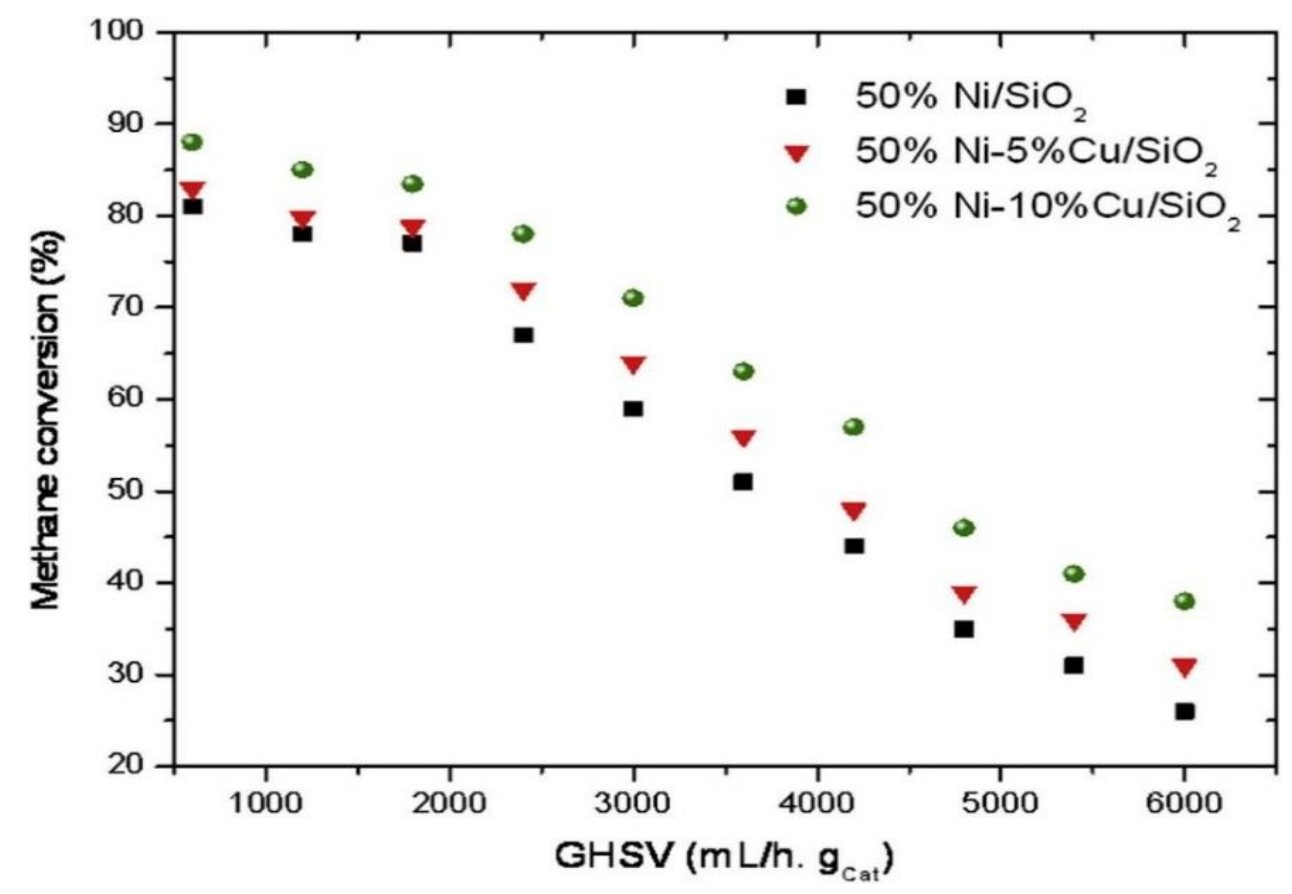

Fig 3: GHSV of reactant vs Catalytic Activity at $1023 \mathrm{~K}$; Reproduced with permission from Saraswat, Copyright 2013 Elsevier [75]

\subsection{Metal loadings}

\subsubsection{Performance of Catalyst}

The effects of metal loadings are highly significant in TCD of $\mathrm{CH}_{4}$. Manoj Pudukudy et al. [37] compared the effects of increasing metal loadings on the catalyst support. The authors impregnated $10-50 \% \mathrm{Ni}$ on $\mathrm{TiO}_{2}$ and performed $\mathrm{TCD}$ at $973 \mathrm{~K}$. The results showed that the $\mathrm{CH}_{4}$ conversions increased periodically with an increase in metal loadings. The high performance of $50 \% \mathrm{Ni} / \mathrm{TiO}_{2}$ was due to the increased availability of $\mathrm{NiO}$ on the surface of the catalyst. The effects of increasing 
the amount of $\mathrm{Cu}$ impregnated on $\mathrm{Ni} / \mathrm{Al}_{2} \mathrm{O}_{3}$ was also reported in [73]. The addition of higher amounts of $\mathrm{Cu}$ drastically increased the $\mathrm{CH}_{4}$ conversions and catalyst stability by keeping the catalyst surface and active surface clean for $\mathrm{CH}_{4}$ dissociation. By increasing the amount of $\mathrm{Cu}$ to $15 \%$, an increase in $\mathrm{CH}_{4}$ was observed. However, a further increase in the $\mathrm{Cu}$ content reduced the stability due to the quasi-liquid state of the catalyst. Similar discussions were also made by other researchers where the conversions increased linearly with the metal loading to a certain extent and then dropped drastically owing to the agglomeration of the particles $[89,90]$. The $\mathrm{CH}_{4}$ conversions along with metal compositions of some of the catalysts have been presented in Table 4 .

Table 4: Effect of Metal Loadings *

\begin{tabular}{|c|c|c|c|}
\hline Sr. No & Metal Loadings & $\begin{array}{l}\text { *Conversion/Yield } \\
(\%)\end{array}$ & Ref \\
\hline 1. & $10 \% \mathrm{Ni} / \mathrm{TiO}_{2}$ & (a) 27 & [37] \\
\hline 2. & $20 \% \mathrm{Ni} / \mathrm{TiO}_{2}$ & (a) 30 & [37] \\
\hline 3. & $30 \% \mathrm{Ni} / \mathrm{TiO}_{2}$ & (a) 33 & [37] \\
\hline 4. & $40 \% \mathrm{Ni} / \mathrm{TiO}_{2}$ & (a) 37 & [37] \\
\hline 5. & $50 \% \mathrm{Ni} / \mathrm{TiO}_{2}$ & (a) 42 & [73] \\
\hline 6. & $50 \% \mathrm{Ni}-5 \% \mathrm{Cu} / \mathrm{Al}_{2} \mathrm{O}_{3}$ & (b) 20 & [73] \\
\hline 7. & $50 \% \mathrm{Ni}-10 \% \mathrm{Cu} / \mathrm{Al}_{2} \mathrm{O}_{3}$ & (b) 79 & [73] \\
\hline 8. & $50 \% \mathrm{Ni}-15 \% \mathrm{Cu} / \mathrm{Al}_{2} \mathrm{O}_{3}$ & (b) 84 & [73] \\
\hline 9. & $50 \% \mathrm{Ni}-10 \% \mathrm{Fe}-5 \% \mathrm{Cu} / \mathrm{Al}_{2} \mathrm{O}_{3}$ & (b) 70 & [90] \\
\hline 10. & $50 \% \mathrm{Ni}-10 \% \mathrm{Fe}-10 \% \mathrm{Cu} / \mathrm{Al}_{2} \mathrm{O}_{3}$ & (b) 81 & [90] \\
\hline
\end{tabular}

*Dependent on reaction conditions ${ }^{(a)} \mathrm{H}_{2}$ Yield ${ }^{(\mathbf{b})} \mathrm{CH}_{4}$ Conversions

\subsubsection{Morphology of Carbon}

The effect of metal loadings on the morphology of the carbon deposited on the surface of the catalyst was discussed by Awadallah et al. [43]. The authors reported that wider CNF is formed because of impregnating higher metal loadings on the support. It is reported that the growth mechanism of CNF takes place in the following steps. 
- Dissociation of $\mathrm{CH}_{4}$ over the surface of the catalyst to evolve $\mathrm{H}_{2}$ and elemental carbon.

- Diffusion of carbon through the metals.

- Formation of CNF on the active sites of the catalyst.

Interestingly, the metal support interaction (MSI) affected the morphology of the carbon. At low metal loadings, the base growth mechanism (BGM) dominates while in higher metal loadings, tip growth mechanism (TGM) plays its role. Therefore, larger and broader CNF and CNT are formed at higher metal loadings due to particle agglomerations and tip growth mechanism. Fig 4 shows the TEM images of carbon formed on $10 \% \mathrm{Co}-\mathrm{Mo} / \mathrm{Al}_{2} \mathrm{O}_{3}$ and $20 \% \mathrm{Co}-\mathrm{Mo} / \mathrm{Al}_{2} \mathrm{O}_{3}$ respectively.
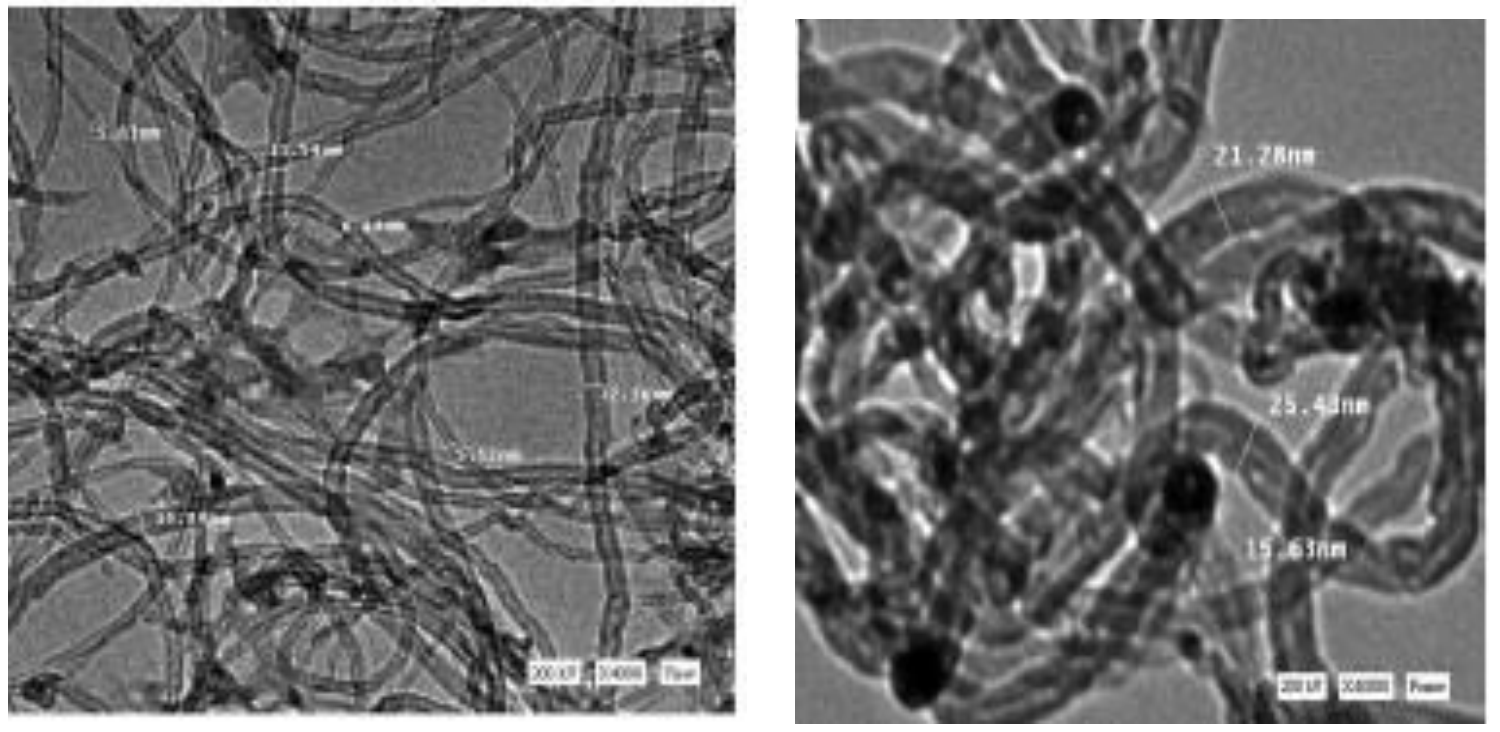

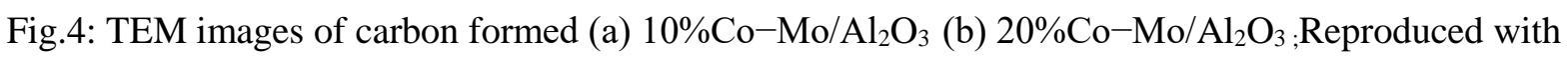

permission from A. E. Awadallah, Copyright 2014 Elsevier [43]

Therefore, to obtain maximum output from the catalyst as of $\mathrm{CH}_{4}$ conversions, an optimum set of reaction parameters is an essential aspect. It is believed that the increase in reaction temperatures increase the $\mathrm{CH}_{4}$ conversions but, due to the high rate of reaction, an ample amount of carbon gets accumulated on the catalyst surface and deactivates it. Furthermore, the increase in GHSV restricts the catalytic activity. The low rate of $\mathrm{CH}_{4}$ diffusion on the surface of the catalyst, due to the 
reduced contact time between the catalyst and feedstock, is often cited as a reason behind low yield at higher space velocities. The effect of higher metal loadings and the impregnation of promoters is also worth mentioning. TCD is a catalyst-based reaction, and the overall efficiency of the reaction depends upon the active sites available for $\mathrm{CH}_{4}$ adsorption. So, better results are obtained at higher metal loadings.

\section{TCD over admixtures as Feedstocks}

TCD is an environmentally friendly technique to produce pure $\mathrm{H}_{2}$ and CNF as a by-product. The major drawback of TCD limiting its industrial applications is the catalyst deactivation due to the encapsulation of less reactive carbon on the catalyst surface, which is described in the previous section [95]. The mechanism of catalyst deactivation due to deposition of carbon has been elaborated as $[96,97]$.

- The formation of CNF which is also called the initial stage of deactivation of the catalyst.

- The rapid deactivation of the catalyst due to the encapsulation of the active phase of the catalyst.

- The complete deactivation of the catalyst due to the detachment of metal from support.

The researchers thoroughly reviewed this problem and came up with two distinct solutions, i.e. cofeeding of $\mathrm{CH}_{4}$ with other hydrocarbons and regeneration of spent catalyst by treating it with $\mathrm{O}_{2}$, $\mathrm{CO}_{2}$, and $\mathrm{H}_{2} \mathrm{O}$ at very high temperatures $[98,99]$. The co-feeding of $\mathrm{CH}_{4}$ with other hydrocarbons, either alternatively or collectively, enhances the catalyst deactivation [23]. These hydrocarbons produce carbon which is much more reactive as compared to carbon eliminated from $\mathrm{CH}_{4}$. The activity of carbon originating from different hydrocarbons is in of the order $\mathrm{C}_{\text {benzene }}>\mathrm{C}_{\text {acetylene }}>$

$\mathrm{C}$ ethylene $>\mathrm{C}_{\text {propane }}$ and $\mathrm{C}$ methane [100]. Limited work has been done on co-feeding of $\mathrm{CH}_{4}$ with other hydrocarbons to stabilize the catalyst activity and deactivation time. Most studies are carried 
out on ethane [101], $\mathrm{C}_{2} \mathrm{H}_{4}[102,103], \mathrm{C}_{3} \mathrm{H}_{6}$ [100], $\mathrm{C}_{2} \mathrm{H}_{5} \mathrm{OH}[104,105], \mathrm{CH}_{3} \mathrm{OH}[22,23]$ and $\mathrm{C}_{2} \mathrm{H}_{2}$ [106]. Moreover, $\mathrm{CO}_{2}$ [107] and $\mathrm{H}_{2} \mathrm{~S}$ [108] is also used as co-feed with $\mathrm{CH}_{4}$.

\subsection{Ethylene}

Anna Malaika et al. [102] explored the effect of ethylene $\left(\mathrm{C}_{2} \mathrm{H}_{4}\right)$ on the decomposition of $\mathrm{CH}_{4}$ by carbon catalyzed catalysts. It was reported that although $\mathrm{C}_{2} \mathrm{H}_{4}$ also formed a carbonaceous byproduct on the surface of the catalyst as compared to $\mathrm{CH}_{4}$ originated carbon; it has better catalytic properties towards $\mathrm{CH}_{4}$ in CDM reactions [109]. The preliminary study without catalyst resulted in the negligible conversion of $\mathrm{CH}_{4}$. In the initial stage of the carbonaceous catalyzed reaction, the high content of $\mathrm{H}_{2}$ and $\mathrm{CH}_{4}$ with zero amount of $\mathrm{C}_{2} \mathrm{H}_{4}$ showed that at initial stages of TCD, activated carbon catalyze the decomposition of $\mathrm{C}_{2} \mathrm{H}_{4}$ as compared to $\mathrm{CH}_{4}$. With TOS, the concentrations of both $\mathrm{CH}_{4}$ and $\mathrm{C}_{2} \mathrm{H}_{4}$ reached a plateau. TCD of a mixture of $\mathrm{CH}_{4}$ and $\mathrm{C}_{2} \mathrm{H}_{4}$ is summarized in Eqs. (7)-(9).

$$
\begin{aligned}
& \mathrm{C}_{2} \mathrm{H}_{4} \rightarrow 2 \mathrm{C}+2 \mathrm{H}_{2} \\
& \mathrm{C}_{2} \mathrm{H}_{4} \rightarrow \mathrm{C}+\mathrm{CH}_{4} \\
& \mathrm{CH}_{4} \rightarrow \mathrm{C}+2 \mathrm{H}_{2}
\end{aligned}
$$

The TCD was carried out at three different reaction temperatures, and concentration of $\mathrm{C}_{2} \mathrm{H}_{4}$ in the feedstock and their effects on $\mathrm{H}_{2}$ concentration have been explained in Fig 5. At higher reaction temperatures, the $\mathrm{CH}_{4}$ conversions were relatively high as equilibrium constant moved towards products formation. For each catalyst and reaction temperature, the addition of $\mathrm{C}_{2} \mathrm{H}_{4}$ leads to an increase in $\mathrm{H}_{2}$ yield and the catalyst deactivation time was decreased. $\mathrm{C}_{2} \mathrm{H}_{4}$ is expensive gas, and its usage in TCD reactions increases the overall operating cost of the process. Anna Malaika et al. [103] produced $\mathrm{C}_{2} \mathrm{H}_{4}$ in situ by oxidative coupling of $\mathrm{CH}_{4}(\mathrm{OCM})$ during TCD. The OCM reaction 
was carried out over $\mathrm{Na} / \mathrm{CaO}$, or $\mathrm{Li} / \mathrm{MgO}$ synthesized by the impregnation method, while the TCD catalyst was activated carbon.

The pilot study suggested that at $1123 \mathrm{~K}$ reaction temperature, $0.8 \mathrm{~g}$ of catalyst and $10 \% \mathrm{O}_{2}$ mixed with $\mathrm{CH}_{4}$ gave higher amounts of $\mathrm{C}_{2} \mathrm{H}_{4}$ during OCM reactions. Therefore, in the first level of TCD-OCM reaction $\mathrm{CH}_{4}$ mixed with oxygen was passed over metal oxide catalyst resulting in the formation of $\mathrm{C}_{2} \mathrm{H}_{4}$. In the next stage, the unreacted $\mathrm{CH}_{4}$ with post reaction gases was subjected to activated carbon. It was reported that although this method can be effective in restricting the deactivation of the catalyst, the formation of $\mathrm{CO}_{2}$, water vapors, and unreacted $\mathrm{C}_{2} \mathrm{H}_{6}$ restricts its applications industrially where pure $\mathrm{H}_{2}$ is required as feedstock.

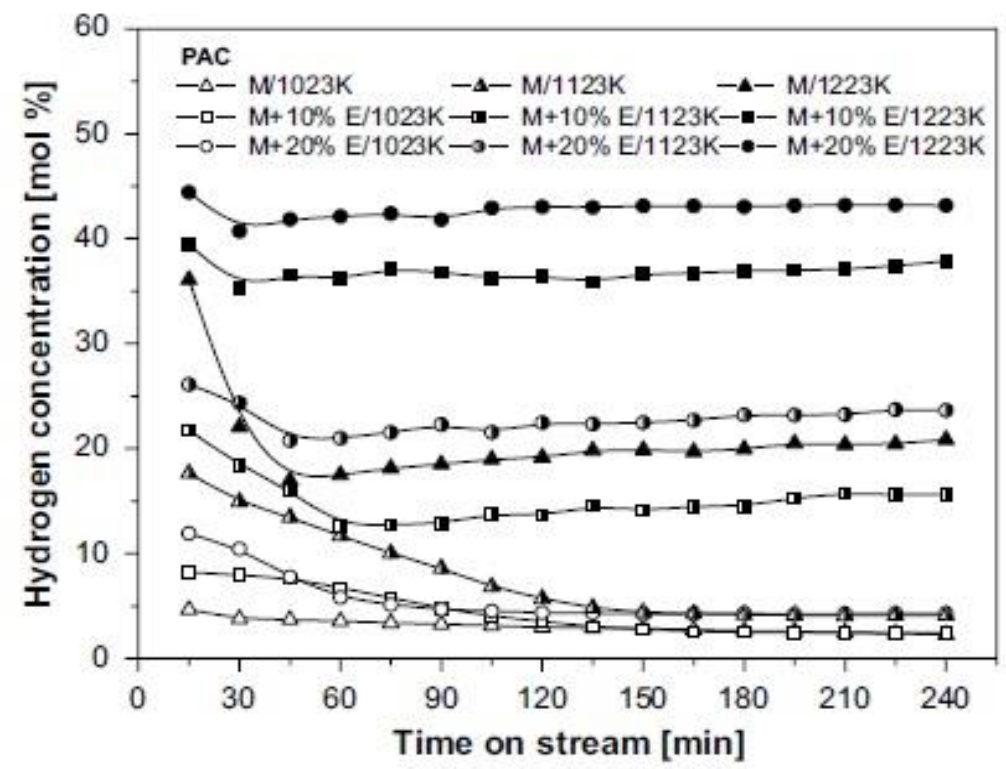

Fig 5: Influence of $\mathrm{C}_{2} \mathrm{H}_{4}$ on $\mathrm{H}_{2}$ concentrations at different reaction parameters; Reproduced with permission from A. Malaika, Copyright 2009 Elsevier [102]

\subsection{Propylene}

The first attempt by employing propylene $\left(\mathrm{C}_{3} \mathrm{H}_{6}\right)$ as co-feed with $\mathrm{CH}_{4}$ for TCD reaction was reported by Anna Malaika et al. [100] because $\mathrm{C}_{3} \mathrm{H}_{6}$ is cheaper than $\mathrm{C}_{2} \mathrm{H}_{4}$ as in Fig 6. It was reported that the decomposition of $\mathrm{C}_{3} \mathrm{H}_{6}$ results in the formation of a variety of hydrocarbons 
including $\mathrm{H}_{2}, \mathrm{CH}_{4}, \mathrm{C}_{2} \mathrm{H}_{4}, \mathrm{C}_{3} \mathrm{H}_{6}, \mathrm{C}_{2} \mathrm{H}_{6}$, and $\mathrm{C}_{3} \mathrm{H}_{8}$ thus making its reaction mechanism difficult to comprehend. Apart from the detection of these gases by chromatographic analysis of post reaction gases, the deposition of active carbon as a by-product on the surface of the catalyst was also confirmed by SEM analysis. The authors have mentioned that though $\mathrm{H}_{2}$ is produced by the catalytic decomposition of $\mathrm{C}_{3} \mathrm{H}_{6}$ and $\mathrm{CH}_{4}$ while also consumed by the hydrogenation of $\mathrm{C}_{3} \mathrm{H}_{6}$ and $\mathrm{C}_{2} \mathrm{H}_{4}$ into $\mathrm{C}_{3} \mathrm{H}_{8}$ and $\mathrm{C}_{2} \mathrm{H}_{6}$ respectively. Thus, the total amount of $\mathrm{H}_{2}$ produced as the product also depends on the intake during hydrogenation reactions. The comparative study was made by using three types of activated carbon catalyst, at different reaction temperatures and different amount of $\mathrm{C}_{3} \mathrm{H}_{6}$ in the feedstock. The catalyst deactivation time improved at higher reaction temperatures due to the formation of filamentous carbon on the surface of the catalyst. Fig 6 shows that the addition of $\mathrm{C}_{3} \mathrm{H}_{6}$ has improved the $\mathrm{H}_{2}$ production quite significantly.

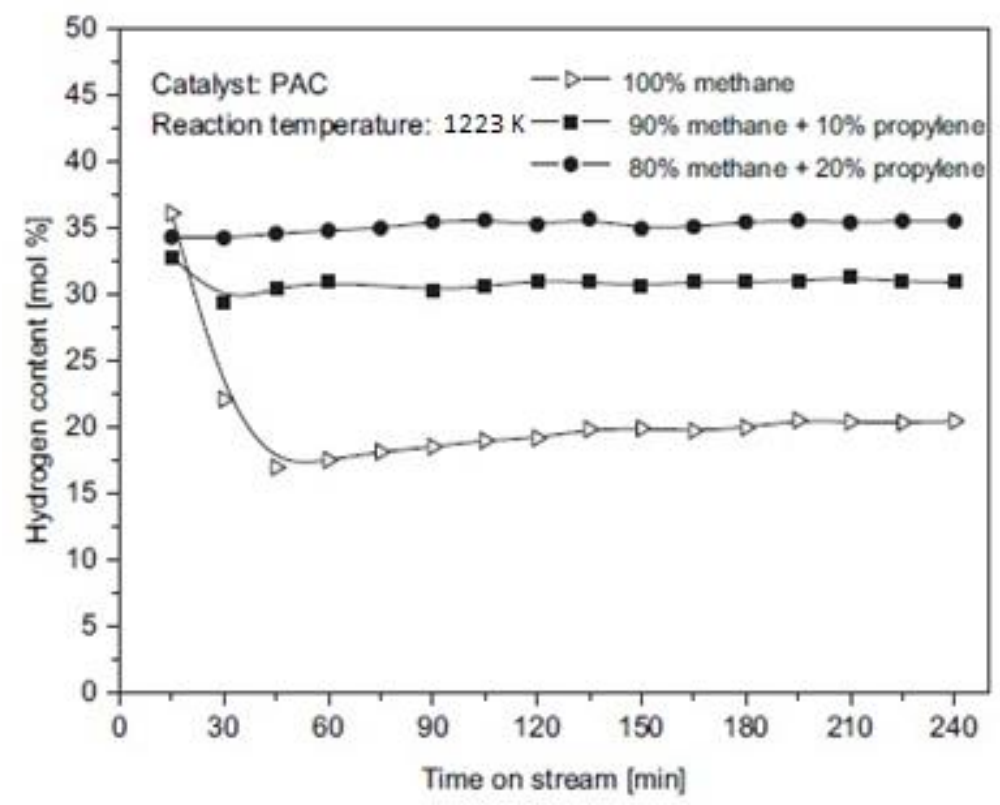

Fig 6: Influence of $\mathrm{C}_{3} \mathrm{H}_{6}$ on $\mathrm{H}_{2}$ concentrations at different reaction parameters; Reproduced with permission from A. Malaika, Copyright 2010 Elsevier [100] 


\subsection{Hydrogen Sulphide}

The addition of hydrogen sulphide $\left(\mathrm{H}_{2} \mathrm{~S}\right)$ to catalytic decomposition of $\mathrm{CH}_{4}$ is of great practical significance. The effects of adding a small number of $\mathrm{H}_{2} \mathrm{~S}\left(0.5-1\right.$ vol. \%) in feedstock on $\mathrm{CH}_{4}$ decomposition over activate carbon, Ni-based catalyst and a mixture of both was investigated in [108]. It was reported that the addition of $1 \% \mathrm{H}_{2} \mathrm{~S}$ increased the conversion of $\mathrm{CH}_{4}$ by $5 \%$ in the results without deactivating the carbonaceous catalyst which supports the previous study on tolerance of carbonaceous catalyst to sulphur compounds [101]. This observation makes carbon catalyst superior to the metallic catalyst in this specific area as the latter are poisoned by sulphur compounds [110]. It was also worth noted $\mathrm{CH}_{4}$ conversions were accelerated due to the formation of $\mathrm{HS}$ radicles which can attack $\mathrm{CH}_{4}$ molecules at higher temperatures resulting in $\mathrm{CH}_{4}$ radicles and elemental carbon.

\subsection{Ethanol}

The effect of ethanol $\left(\mathrm{C}_{2} \mathrm{H}_{5} \mathrm{OH}\right)$ on the catalytic decomposition of $\mathrm{CH}_{4}$ was explored by Paulina Rechnia et al. [105]. $\mathrm{C}_{2} \mathrm{H}_{5} \mathrm{OH}$ was dozed alternately with $\mathrm{CH}_{4}$ at reaction temperatures of 1023-1223 K by using activated carbon as catalyst synthesized by hazelnut shells. The authors explained that apart from $\mathrm{H}_{2}$, and unreacted $\mathrm{CH}_{4}$ in the outflow stream minor concentrations of $\mathrm{CO}, \mathrm{CO}_{2}, \mathrm{H}_{2} \mathrm{O}$, and $\mathrm{C}_{2} \mathrm{H}_{6}$ were detected by gas chromatography. The preliminary study was made on the decomposition of un-diluted $\mathrm{CH}_{4}$ at different reaction temperatures. The lowest $\mathrm{CH}_{4}$ conversion was obtained at $1023 \mathrm{~K}$, i.e. $3.4 \%$ that increased to $26 \%$ at $1223 \mathrm{~K}$. In the next stage of the experiment, $\mathrm{C}_{2} \mathrm{H}_{5} \mathrm{OH}$ was introduced into the reactor at three different reaction temperatures. The choice of employing $\mathrm{C}_{2} \mathrm{H}_{5} \mathrm{OH}$ as an additive was based on the prior study that apart from $\mathrm{CH}_{4}$ and $\mathrm{H}_{2}$ production it also produces $\mathrm{C}_{2} \mathrm{H}_{4}$ which works against catalyst deactivation [100]. The decomposition of $\mathrm{CH}_{4}$ and $\mathrm{C}_{2} \mathrm{H}_{5} \mathrm{OH}$ was carried out at the same reaction temperatures. The results 
obtained at all three reaction temperatures were quite interesting. The most optimum results were obtained at $1123 \mathrm{~K}$ in which the cyclic addition of $\mathrm{C}_{2} \mathrm{H}_{5} \mathrm{OH}$ leads to an increase in $\mathrm{CH}_{4}$ conversion as shown in Fig 7. It is worth noting that at $1023 \mathrm{~K}$ the $\mathrm{CH}_{4}$ conversions decreased by the introducing $\mathrm{C}_{2} \mathrm{H}_{5} \mathrm{OH}$ since it was not converted completely. At $1223 \mathrm{~K}$ total $\mathrm{C}_{2} \mathrm{H}_{5} \mathrm{OH}$ and $\mathrm{C}_{2} \mathrm{H}_{4}$ were decomposed, and a high degree of graphitization of carbon originated from $\mathrm{CH}_{4}$ and $\mathrm{C}_{2} \mathrm{H}_{5} \mathrm{OH}$ inhibited higher $\mathrm{CH}_{4}$ conversions. As the amount of $\mathrm{C}_{2} \mathrm{H}_{5} \mathrm{OH}$ was increased, the concentration of $\mathrm{CO}$ also increased. Alternatively, the production of $\mathrm{C}_{2} \mathrm{H}_{4}$ and water as the concentration of both gases were found the same. Several other side reactions also occurred in TCD of $\mathrm{CH}_{4}$ and $\mathrm{C}_{2} \mathrm{H}_{5} \mathrm{OH}$. It was reported that these reactions occurred as shown in Eqs (10)-(16). [104, 111].

$$
\begin{aligned}
& \mathrm{CH}_{3} \mathrm{CH}_{2} \mathrm{OH} \rightarrow \mathrm{CO}+\mathrm{H}_{2}+\mathrm{CH}_{4} \\
& \mathrm{CH}_{3} \mathrm{CH}_{2} \mathrm{OH} \rightarrow \mathrm{C}+\mathrm{CO}+3 \mathrm{H}_{2} \\
& \mathrm{CH}_{3} \mathrm{CH}_{2} \mathrm{OH} \rightarrow \mathrm{C}_{2} \mathrm{H}_{4}+\mathrm{H}_{2} \mathrm{O} \\
& \mathrm{C}_{2} \mathrm{H}_{4} \rightarrow 2 \mathrm{C}+2 \mathrm{H}_{2} \\
& \mathrm{C}_{2} \mathrm{H}_{4} \rightarrow \mathrm{C}+\mathrm{CH}_{4} \\
& \mathrm{H}_{2} \mathrm{O}+\mathrm{C} \rightarrow \mathrm{CO}+\mathrm{H}_{2} \\
& 2 \mathrm{H}_{2} \mathrm{O}+\mathrm{C} \rightarrow \mathrm{CO}_{2}+2 \mathrm{H}_{2}
\end{aligned}
$$




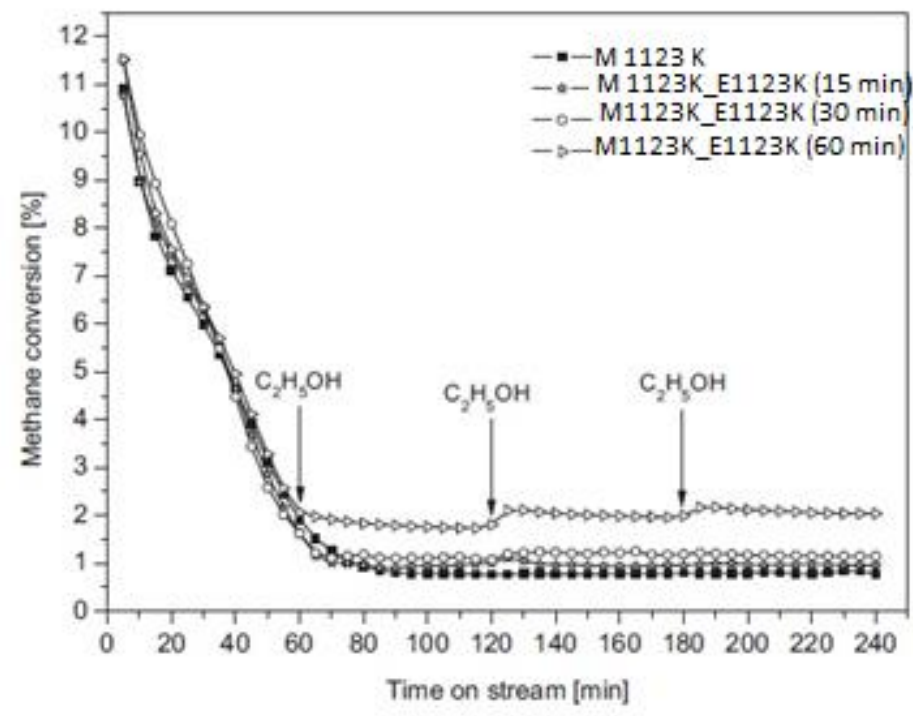

Fig 7: $\mathrm{C}_{2} \mathrm{H}_{5} \mathrm{OH}$ Assisted $\mathrm{CH}_{4}$ decomposition at $1123 \mathrm{~K}$; Reproduced with permission from $\mathrm{P}$.

Rechnia, Copyright 2012 Elsevier [105]

\subsection{2\% Methanol/Methane}

The effect of $2 \%$ premixed methanol in methane used as feedstock for TCD has been explored by our group. Different composition of Ni-based catalyst was synthesized by wet impregnation method [142]. The results showed that methane conversions increased proportionally with metal loadings and $50 \% \mathrm{Ni} / \mathrm{Al}_{2} \mathrm{O}_{3}$ gave the best results. Additionally, the addition of $\mathrm{Pd}$ on $\mathrm{Ni}$-based catalyst having drastic effects on the activity and stability of the catalyst was also reported [149]. Furth more, the activity and stability of $\mathrm{Cu}$ promoted Ni-based catalyst was also evaluated in [112]

\section{Kinetics and reaction mechanism of TCD}

Kinetic studies are often done to find an appropriate reaction rate model that correlates the experimental data, describes the rate of reaction, the order of reaction and activation energies [113]. The proper understanding of kinetics models can further optimize the catalyst design and improves the overall efficiency of the process concerning $\mathrm{CH}_{4}$ consumption rates and carbon depositions. SRM is often termed as one of the early methods used in industries for $\mathrm{H}_{2}$ production, 
but the formation of ample amount of greenhouse gases opens the floor for further research in finding an environment for $\mathrm{H}_{2}$ production [114]. TCD of $\mathrm{CH}_{4}$ is widely explored by scholars, and a series of catalysts are being synthesized reported in the literature (c.f. Table 1-3) having specific reaction order and activation energies (c.f. Table 5) [115]. Ashik et al. [116] thoroughly studied the reaction mechanism of $\mathrm{TCD}$ over $\mathrm{Ni} / \mathrm{SiO}_{2}$ nanocatalyst prepared by co-precipitation cum modified Stober method. The studies were made around the reaction temperature of $823-923 \mathrm{~K}$ and pressure of $21-81 \mathrm{kPa}$. The $\mathrm{CH}_{4}$ conversions increased with reaction temperature and partial pressures, but the catalyst was subjected to an early deactivation due to the formation of CNF resulted in high reaction rates at higher temperatures as shown in Fig 8. 

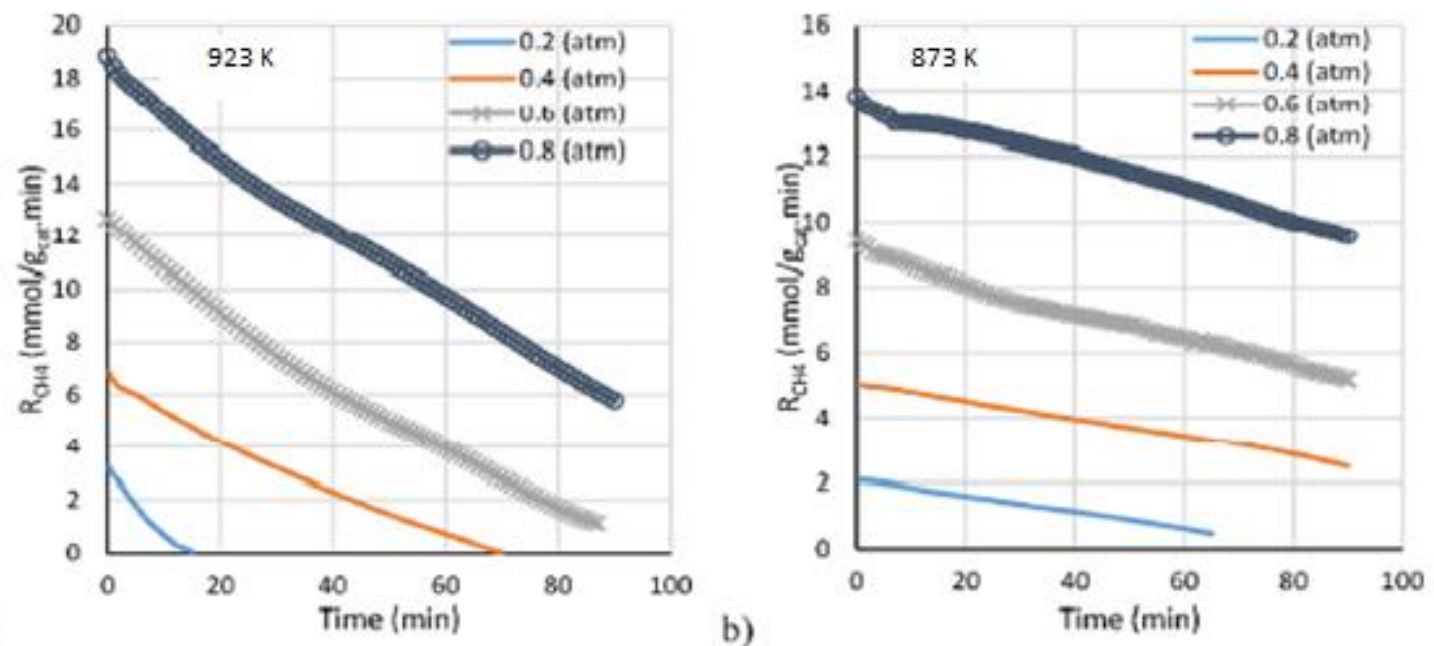

a)

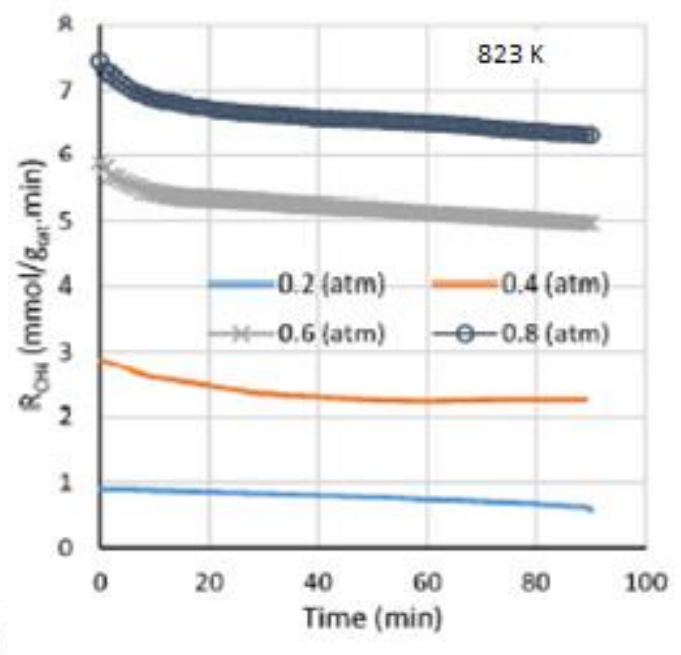

Fig 8: Reaction time vs $\mathrm{CH}_{4}$ decomposition; Reproduced with permission from U. Ashik,

Copyright 2017 Elsevier [116]

The authors reported that as the TCD of $\mathrm{CH}_{4}$ occurs in various steps and the reaction kinetics of each step is still under study, this makes the overall mechanism of TCD extremely complicated. Empirical model law based on power law was used in this study for computing the reaction order and activation energy. In another study, the reaction kinetics over $\mathrm{Ni}-\mathrm{Cu}-\mathrm{Co}$ was studied, and the activation energy was calculated by Arrhenius plot shown in Fig 9 [117].

Recent studied made by [118] reported that the initial step of $\mathrm{CH}_{4}$, i.e. breakage of bonds in TCD over the metallic catalyst is the rate determining step since the activation energy decreased from 
$440 \mathrm{~kJ} \mathrm{~mol}^{-1}$ to $65 \mathrm{~kJ} \mathrm{~mol}^{-1}$ over Ni (100) catalyst at high temperatures. Similarly, Maryam et al. [119] carried kinetic modelling of $\mathrm{CH}_{4}$ decomposition at a temperature range of 823-923 K over $\mathrm{Ni}-\mathrm{Cu} / \mathrm{MgO}$ and estimated around $50.4 \mathrm{~kJ} \mathrm{~mol}^{-1}$ of activation energy. The results also revealed that the catalyst deactivation was dependent on TOS, reaction temperature, and partial pressures. Nasir et al. [96] stated that a reaction order and activation energy of 2.65 and $61.77 \mathrm{~kJ} \mathrm{~mol}^{-1}$ respectively was obtained by carrying out TCD over Ni/Zeolite catalyst. The kinetic data indicated that the optimum reaction temperature and partial $\mathrm{CH}_{4}$ pressures must be maintained to get the highest performance from the catalyst in terms of catalyst activity and stability.

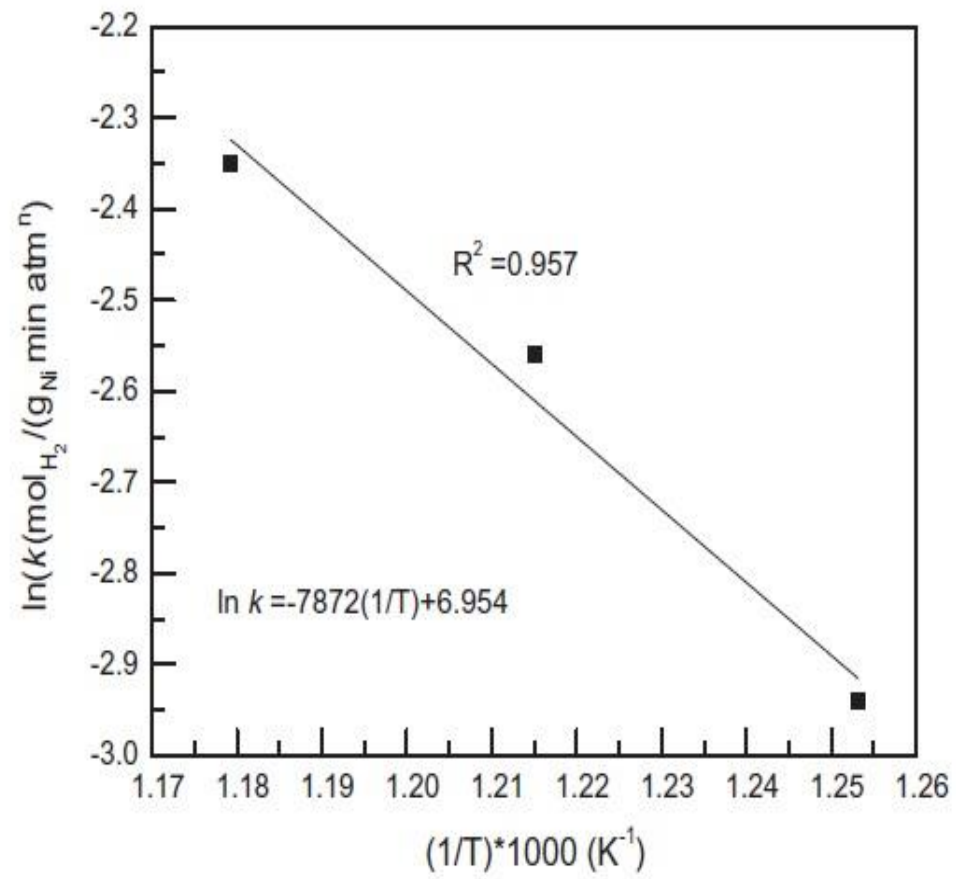

Fig 9: Activation Plot of $\mathrm{Ni}-\mathrm{Cu}-\mathrm{Co}$; Reproduced with permission from H. Y. Wang, Copyright 2014 Elsevier [117] 
The activation energy and order of reaction of some of the highly active catalyst in TCD of $\mathrm{CH}_{4}$ has been shown in Table 5.

Table 5: Activation Energy of First-order TCD over Metal Based Catalyst by Empirical Model

\begin{tabular}{ccc}
\hline Catalyst & Activation Energy $\mathrm{E}_{\mathrm{a}}\left(\mathrm{kJ} \mathrm{mole}^{-1}\right)^{(\mathrm{a})}$ & Ref \\
\hline $\mathrm{Ni}$ & 65.4 & {$[117]$} \\
$\mathrm{Ni}$ & 64.6 & {$[120]$} \\
$\mathrm{Ni} / \mathrm{Zeolite}$ & 61.77 & {$[96]$} \\
$\mathrm{Ni} / \mathrm{TiO}_{2}$ & 60 & {$[121]$} \\
$\mathrm{Ni} / \mathrm{SiO}_{2}$ & 29.5 & {$[122]$} \\
$\mathrm{Ni}-\mathrm{Cu} / \mathrm{Al}_{2} \mathrm{O}_{3}$ & 46 & {$[123]$} \\
$\mathrm{Ni}-\mathrm{Cu} / \mathrm{MgO}$ & 50.4 & {$[119]$} \\
$\mathrm{Ni}-\mathrm{Cu}-\mathrm{Co}$ & 67.5 & {$[117]$} \\
\hline
\end{tabular}

(a)Dependent Upon Reaction Parameters

The comparison of different hydrogen production techniques has been furnished in Table 6. The liberation of ample amount of greenhouse gases marks SRM, DRM and POM unfavorable techniques for $\mathrm{H}_{2}$ production. Moreover, the separation of $\mathrm{H}_{2}$ from synthesis gas requires heavy equipment that increases the overall cost of the process. TCD is a nonoxidative technique in which $\mathrm{CH}_{4}$ is decomposed into $\mathrm{H}_{2}$ and elemental carbon as a by-product. Furthermore, among all suggested processes TCD occurs at the lowest reaction temperature because metallic catalysts are used. 
Table 6: Comparison in between $\mathrm{H}_{2}$ Production Techniques

\begin{tabular}{|c|c|c|c|c|}
\hline & SRM & DRM & POM & TCD \\
\hline Reaction & $\mathrm{CH}_{4}+\mathrm{H}_{2} \mathrm{O} \rightarrow \mathrm{CO}+3 \mathrm{H}_{2}$ & $\begin{array}{l}\mathrm{CH}_{4}+\mathrm{CO}_{2} \rightarrow 2 \mathrm{CO} \\
+2 \mathrm{H}_{2}\end{array}$ & $\mathrm{CH}_{4}+0.5 \mathrm{O}_{2} \rightarrow \mathrm{CO}+2 \mathrm{H}_{2}$ & $\mathrm{CH}_{4} \rightarrow \mathrm{C}+2 \mathrm{H}_{2}$ \\
\hline Advantages & $\begin{array}{l}\text { 1.75-85\% Efficiency } \\
\text { 2.Ancient Technique }\end{array}$ & $\begin{array}{l}\text { 1. Two green House } \\
\text { gases are consumed, } \\
\text { i.e. } \mathrm{CH}_{4} \text { and } \mathrm{CO}_{2} \\
\text { 2. Clean fuel is a } \\
\text { product }\end{array}$ & $\begin{array}{l}\text { 1.60-75\% Efficiency } \\
\text { 2. Low Residence Time } \\
\text { 3.High Reaction Yield }\end{array}$ & $\begin{array}{l}\text { 1. Green and Nonoxidative Technique. } \\
\text { 2.Highly ordered carbon produced as a } \\
\text { by-product. }\end{array}$ \\
\hline Disadvantages & $\begin{array}{l}\text { 1.Costly process. } \\
\text { 2.High reaction } \\
\text { temperature and } \\
\text { pressure required } \\
\text { 3. } \mathrm{H}_{2} \text { must be removed } \\
\text { from synthesis gas }\end{array}$ & $\begin{array}{l}\text { 1. Carbon formation } \\
\text { and sintering. } \\
\text { 2. } \mathrm{H}_{2} \text { must be } \\
\text { removed from } \\
\text { synthesis gas. }\end{array}$ & $\begin{array}{l}\text { 1. Costly technique as it } \\
\text { requires the cryogenic unit } \\
\text { to sperate } \mathrm{O}_{2} \text { from Air } \\
\text { 2. } \mathrm{H}_{2} \text { must be removed from } \\
\text { synthesis gas }\end{array}$ & $\begin{array}{l}\text { 1. Deactivation of the catalyst due to } \\
\text { encapsulation of low active carbon. }\end{array}$ \\
\hline $\mathrm{H}_{2} / \mathrm{CO}$ Ratio & $\mathrm{H}_{2} / \mathrm{CO}$ Ratio: $3: 1$ & $\mathrm{H}_{2} / \mathrm{CO}$ Ratio: $1: 1$ & $\mathrm{H}_{2} / \mathrm{CO}$ Ratio: $2: 1$ & $\mathrm{H}_{2} / \mathrm{CO}$ Ratio: - \\
\hline $\begin{array}{l}\text { Operating } \\
\text { Temperature }\end{array}$ & $973-1273 \mathrm{~K}$ & $1223-1373 \mathrm{~K}$ & $923-1023 \mathrm{~K}$ & $823-1023 \mathrm{~K}$ \\
\hline $\begin{array}{l}\text { Operating } \\
\text { Pressure }\end{array}$ & 3-25 bar & $1 \mathrm{bar}$ & 100 bar & $1 \mathrm{bar}$ \\
\hline
\end{tabular}




\section{Outlook}

TCD has been termed as one of the effective technique to produce $\mathrm{CO}_{\mathrm{X}}$ free $\mathrm{H}_{2}$ that can replace all existing fuels due to clean and abundant energy. The hydrogen produced by this process can be directly employed as feedstock in fuel cells while carbon obtained as by-product can be used as advanced materials and catalysts. The main problems encountered in this process as stated in literature surveys are high reaction temperature, and rapid catalyst deactivation as the formation of carbon destabilizes the adsorption capacity of clean material thus lowering its catalytic activity and stability. In recent years, cumulative efforts have been devoted for the commercialization of TCD, and reaction kinetics, catalyst developments and process parameters have been investigated broadly. However, this process needs further directions. The current article enlightens that TCD can be developed by further theoretical and experimental investigations. It is considered that the future perspective of TCD research is to concentrate on the synthesis of trimetallic catalysts having suitable metals comprising of appropriate compositions. The impregnation of $\mathrm{Mo}, \mathrm{Co}, \mathrm{Fe}, \mathrm{Cu}, \mathrm{Pd}$, $\mathrm{Cr}$ and Pt on the Ni-based catalyst can serve the purpose of industrializing TCD. Furthermore, the mixtures of $\mathrm{CH}_{4}$ with other hydrocarbons like $\mathrm{C}_{6} \mathrm{H}_{6}, \mathrm{H}_{2} \mathrm{~S}, \mathrm{CO}_{2}$, alkanes, and alkanols can be utilized as efficient feedstocks for TCD as it gives better hydrogen yields and improve carbon types towards MWCNTs. The synthesis methods, calcination temperatures, and activation temperatures are also essential to enhance the performance of the catalysts. The suitable synthesis techniques and activation conditions can give a high dispersion of metal on support, robust metal support activation and high resistance to coke. Additionally, the reactor designs must be explored deeply to optimize this process. It is believed that a practical research done on these parameters can give better results in the respective fields. This will help to get ample energy by the combustion 
of $\mathrm{H}_{2}$ by industrializing TCD of $\mathrm{CH}_{4}$. It is also worth mentioning that, industrialization of TCD will assist to tackle the issue of clean energy crisis and GHG emissions which is the root cause of global warming. Moreover, the carbon produced as a by-product will serve as a value-added product as catalyst and power generation.

\section{Conclusion}

TCD has been considered as green and economical method to produce pure $\mathrm{H}_{2}$ and elemental carbon as a by-product without the need of a costly separation method as compared to other techniques, i.e. DRM, SRM and POM. However, a high reaction temperature of TCD and fast deactivation of the catalyst has restricted this process for commercial applications. For this purpose, the metal-based catalysts, i.e. noble and transition metals have been extensively researched to lower the reaction temperature and improve the catalyst stability. $\mathrm{Ni}, \mathrm{Cu}, \mathrm{Co}, \mathrm{Fe}$, and $\mathrm{Pd}$ are the most studied transition metals impregnated on $\mathrm{Al}_{2} \mathrm{O}_{3}, \mathrm{FeO}, \mathrm{MgO}, \mathrm{CeO}_{2}$, and $\mathrm{La}_{2} \mathrm{O}_{3}$. Of all metallic catalysts, Ni-based materials proved to be better due to its low cost, easy availability and excellent catalytic efficiency as compared to other metals. While parameters such as reaction temperature, GHSV, and metal loading also affect the process yields. The co-feeding of $\mathrm{CH}_{4}$ with other feedstock $\mathrm{C}_{2} \mathrm{H}_{4}, \mathrm{C}_{3} \mathrm{H}_{6}, \mathrm{C}_{2} \mathrm{H}_{5} \mathrm{OH}$ and $\mathrm{CH}_{3} \mathrm{OH}$ producing more active carbon as a by-product is proposed to be effective solution to overcome the rapid catalyst deactivation. Lastly, the kinetic study is presented in which the research done by some notable's groups were mentioned based on activation energies. An empirical model based on the power law is considered as the most appropriate model that fits in TCD, and hence the order of reaction and activation energy is calculated. 


\section{Acknowledgement}

The authors gratefully acknowledge Universiti Teknologi PETRONAS, Malaysia in providing the necessary facilities to conduct the work.

\section{References}

[1] H. Y. Wang and A. C. Lua, "Development of metallic nickel nanoparticle catalyst for the decomposition of methane into hydrogen and carbon nanofibers," The Journal of Physical Chemistry C, 2012.116, 26765-26775.

[2] G. Nicoletti, N. Arcuri, G. Nicoletti, and R. Bruno, "A technical and environmental comparison between hydrogen and some fossil fuels," Energy Conversion and Management, 2015. 89, 205-213.

[3] G. Supran and N. Oreskes, "Assessing ExxonMobil's climate change communications (1977-2014)," 2017, 12.

[4] S. N. Khan, S. M. Hailegiorgis, Z. Man, A. M. Shariff, and S. Garg, "Thermophysical properties of concentrated aqueous solution of N-methyldiethanolamine (MDEA), piperazine (PZ), and ionic liquids hybrid solvent for $\mathrm{CO}_{2}$ capture," Journal of Molecular Liquids, 2017. 229, 221-229.

[5] M. Shaikh, A. Shariff, M. Bustam, and G. Murshid, "Measurement and prediction of physical properties of aqueous sodium 1-prolinate and piperazine as a solvent blend for $\mathrm{CO}_{2}$ removal," Chemical Engineering Research and Design, 2015, 102, 378-38.

[6] S. N. Khan, S. M. Hailegiorgis, Z. Man, A. M. Shariff, and S. Garg, "Thermophysical properties of aqueous N-methyldiethanolamine (MDEA) and ionic liquids 1-butyl-3methylimidazolium trifluoromethanesulfonate [bmim][OTf], 1-butyl-3- 
methylimidazolium acetate $[\mathrm{bmim}][\mathrm{Ac}]$ hybrid solvents for $\mathrm{CO}_{2}$ capture," Chemical Engineering Research and Design, 2017. 121, 69-80.

[7] F. Iqbal, M. I. A. Mutalib, M. S. Shaharun, and B. Abdullah, "Synthesis of $\mathrm{ZnFe}_{2} \mathrm{O}_{4}$ Using sol-gel Method: Effect of Different Calcination Parameters," Procedia Engineering, 2016. $148, .787-794$.

[8] I. Jain, "Hydrogen the fuel for 21st century," International journal of hydrogen energy, 2009, 34, 7368-737.

[9] H. F. Abbas and W. W. Daud, "Hydrogen production by methane decomposition: a review," International Journal of Hydrogen Energy, 2010,35, 160-1190.

[10] M. Ball and M. Wietschel, "The future of hydrogen-opportunities and challenges," International journal of hydrogen energy, 2009. 34, 615-62.

[11] M. Balat and M. Balat, "Political, economic and environmental impacts of biomass-based hydrogen," International journal of hydrogen energy, 2009, 34, 3589-3603.

[12] H. Ong, T. Mahlia, and H. Masjuki, "A review on energy scenario and sustainable energy in Malaysia," Renewable and Sustainable Energy Reviews, 2011 15, 639-647.

[13] B. Abdullah, N. A. A. Ghani, and D.-V. N. Vo, "Recent Advances in Dry Reforming of Methane over Ni-based Catalysts," Journal of Cleaner Production, 2017 162. 170-185.

[14] I. S. Locka, S. S. Lockb, N. Dai-viet, and B. Abdullah, "Influence of Palladium on Nibased Catalyst for Hydrogen Production via Thermo-catalytic Methane Decomposition," CHEMICAL ENGINEERING, 2017, 57.

[15] U. Sikander, S. Sufian, and M. Salam, "A review of hydrotalcite based catalysts for hydrogen production systems," International Journal of Hydrogen Energy, 2017. 42, 19851-19868. 
[16] Z. Khan, S. Yusup, M. M. Ahmad, V. S. Chok, Y. Uemura, and K. M. Sabil, "Review on hydrogen production technologies in Malaysia," International Journal of Engineering \& Technology, 2010, 10.

[17] Y. Li, D. Li, and G. Wang, "Methane decomposition to CO x-free hydrogen and nanocarbon material on group 8-10 base metal catalysts: a review," Catalysis today, 2011, 162, $1-48$.

[18] M. Ermakova, D. Y. Ermakov, and G. Kuvshinov, "Effective catalysts for direct cracking of methane to produce hydrogen and filamentous carbon: Part I. Nickel catalysts," Applied Catalysis A: General, 2000, 201, 61-70.

[19] H. J. Alves, C. B. Junior, R. R. Niklevicz, E. P. Frigo, M. S. Frigo, and C. H. CoimbraAraújo, "Overview of hydrogen production technologies from biogas and the applications in fuel cells," international journal of hydrogen energy, 2013. 38, 5215-5225.

[20] U. Ashik, W. W. Daud, and H. F. Abbas, "Production of greenhouse gas free hydrogen by thermocatalytic decomposition of methane-A review," Renewable and Sustainable Energy Reviews, 2015, 44, 221-256,.

[21] K. Srilatha, D. Bhagawan, S. S. Kumar, and V. Himabindu, "Sustainable fuel production by thermocatalytic decomposition of methane-A review," South African Journal of Chemical Engineering, 2017. 24, 156-167.

[22] A.Awad, A. Salam, and B. Abdullah, "Hydrogen Production by Decomposition of Methane and Methanol Mixture over Ni-Pd/Al ${ }_{2} \mathrm{O}_{3}$," Journal of the Japan Institute of Energy,2017, 445-450. 
[23] A. Awad, A. Salam, and B. Abdullah, "Thermocatalytic decomposition of methane/methanol mixture for hydrogen production: Effect of nickel loadings on alumina support," in AIP Conference Proceedings, 2017, p. 020030.

[24] I. Suelves, M. Lázaro, R. Moliner, B. Corbella, and J. Palacios, "Hydrogen production by thermo catalytic decomposition of methane on Ni-based catalysts: influence of operating conditions on catalyst deactivation and carbon characteristics," International Journal of Hydrogen Energy, 2015. 30, 1555-1567.

[25] M. A. Salam and B. Abdullah, "Catalysis mechanism of Pd-promoted $\gamma$-alumina in the thermal decomposition of methane to hydrogen: A density functional theory study," Materials Chemistry and Physics, 2017, 188, 18-23.

[26] U. Ashik, W. W. Daud, and J.-i. Hayashi, "A review on methane transformation to hydrogen and nanocarbon: Relevance of catalyst characteristics and experimental parameters on yield," Renewable and Sustainable Energy Reviews, 2017, 76, 743-767.

[27] L. Zhou, L. R. Enakonda, M. Harb, Y. Saih, A. Aguilar-Tapia, S. Ould-Chikh, et al., "Fe catalysts for methane decomposition to produce hydrogen and carbon nano materials," Applied Catalysis B: Environmental, 2015, 208, 44-59.

[28] A. A. Ibrahim, A. H. Fakeeha, A. S. Al-Fatesh, A. E. Abasaeed, and W. U. Khan, "Methane decomposition over iron catalyst for hydrogen production," International Journal of Hydrogen Energy, 2015. 40, 7593-7600.

[29] A. H. Fakeehaa, A. A. Ibrahima, A. S. Al Fatesha, W. U. Khana, Y. A. Mohammeda, A. E. Abasaeeda, et al., "Fe Supported Alumina Catalyst for Methane Decomposition: Effect of Co Coupling," Int. J. of Sustainable Water \& Environmental Systems, 2016. 8,00-00. 
[30] S. Takenaka, H. Ogihara, I. Yamanaka, and K. Otsuka, "Decomposition of methane over supported-Ni catalysts: effects of the supports on the catalytic lifetime," Applied Catalysis A: General, 2001, 217, 101-110.

[31] N. Bayat, M. Rezaei, and F. Meshkani, "COx-free hydrogen and carbon nanofibers production by methane decomposition over nickel-alumina catalysts," Korean Journal of Chemical Engineering, 2016, 33, 490-49.

[32] S. Makvandi and S. Alavi, "COx free hydrogen production by catalytic decomposition of methane over porous $\mathrm{Ni} / \mathrm{Al}_{2} \mathrm{O}_{3}$ catalysts," Iranian Journal of Chemical Engineering, 2011. $8,24-33$.

[33] W. Ahmed, M. N. El-Din, A. Aboul-Enein, and A. Awadallah, "Effect of textural properties of alumina support on the catalytic performance of $\mathrm{Ni} / \mathrm{Al}_{2} \mathrm{O}_{3}$ catalysts for hydrogen production via methane decomposition," Journal of Natural Gas Science and Engineering, 2015. 25, 359-366.

[34] J. F. Pola, M. A. Valenzuela, I. A. Córdova, and J. Wang, "Hydrogen production via methane decomposition using $\mathrm{Ni}$ and $\mathrm{Ni}-\mathrm{Cu}$ catalysts supported on $\mathrm{MgO}, \mathrm{Al}_{2} \mathrm{O}_{3}$ and $\mathrm{MgAl}_{2} \mathrm{O}_{4}, "$ MRS Online Proceedings Library Archive, 2010,1279.

[35] M. Pudukudy, Z. Yaakob, and M. S. Takriff, "Methane decomposition into COx free hydrogen and multiwalled carbon nanotubes over ceria, zirconia and lanthana supported nickel catalysts prepared via a facile solid state citrate fusion method," Energy Conversion and Management, 2016 126, 302-315.

[36] S. Takenaka, H. Ogihara, and K. Otsuka, "Structural change of Ni species in $\mathrm{Ni} / \mathrm{SiO}_{2}$ catalyst during decomposition of methane," Journal of Catalysis, 202. 208, 54-63. 
[37] M. Pudukudy, Z. Yaakob, A. Kadier, M. S. Takriff, and N. S. M. Hassan, "One-pot solgel synthesis of $\mathrm{Ni} / \mathrm{TiO}_{2}$ catalysts for methane decomposition into $\mathrm{COx}$ free hydrogen and multiwalled carbon nanotubes," International Journal of Hydrogen Energy,2017, 42, 16495-16513.

[38] A. E. Awadallah, M. S. Mostafa, A. A. Aboul-Enein, and S. A. Hanafi, "Hydrogen production via methane decomposition over $\mathrm{Al}_{2} \mathrm{O}_{3}-\mathrm{TiO}_{2}$ binary oxides supported $\mathrm{Ni}$ catalysts: Effect of Ti content on the catalytic efficiency," Fuel, 2014, 129, 68-77.

[39] J. Pinilla, R. Utrilla, R. Karn, I. Suelves, M. Lázaro, R. Moliner, et al., "High temperature iron-based catalysts for hydrogen and nanostructured carbon production by methane decomposition," International Journal of hydrogen energy, 2011, 36, 7832-7843.

[40] A. A. Ibrahim, A. S. Al- Fatesh, W. U. Khan, M. A. Soliman, A. Otaibi, L. Raja, et al., "Influence of support type and metal loading in methane decomposition over iron catalyst for hydrogen production," Journal of the Chinese Chemical Society, 2015, 62, 592-599.

[41] A. H. Fakeeha, A. A. Ibrahim, W. U. Khan, K. Seshan, R. L. Al Otaibi, and A. S. AlFatesh, "Hydrogen production via catalytic methane decomposition over alumina supported iron catalyst," Arabian Journal of Chemistry,2016, 11, 405-41.

[42] A. E. Awadallah and A. A. Aboul-Enein, "Catalytic decomposition of methane to COxfree hydrogen and carbon nanotubes over $\mathrm{Co}-\mathrm{W} / \mathrm{MgO}$ catalysts," Egyptian Journal of Petroleum, 2015, 24, 299-30.

[43] A. E. Awadallah, A. A. Aboul-Enein, and A. K. Aboul-Gheit, "Effect of progressive Co loading on commercial $\mathrm{Co}-\mathrm{Mo} / \mathrm{Al}_{2} \mathrm{O}_{3}$ catalyst for natural gas decomposition to $\mathrm{COx}$-free hydrogen production and carbon nanotubes," Energy Conversion and Management, 2014. $77,143-15$. 
[44] L. Tang, D. Yamaguchi, N. Burke, D. Trimm, and K. Chiang, "Methane decomposition over ceria modified iron catalysts," Catalysis Communications, 2010,11, 1215-1219.

[45] A. E. Awadallah, A. A. Aboul-Enein, and A. K. Aboul-Gheit, "Impact of group VI metals addition to $\mathrm{Co} / \mathrm{MgO}$ catalyst for non-oxidative decomposition of methane into COx-free hydrogen and carbon nanotubes," Fuel, vol. 129, 27-36.

[46] A. E. Awadallah, M. S. Abdel-Mottaleb, A. A. Aboul-Enein, M. M. Yonis, and A. K. Aboul-Gheit, "Catalytic decomposition of natural gas to $\mathrm{CO} / \mathrm{CO}_{2}$-free hydrogen production and carbon nanomaterials using mgO-Supported monometallic iron family catalysts," Chemical Engineering Communications,2015, 202, 163-174.

[47] M. Pudukudy and Z. Yaakob, "Methane decomposition over Ni, Co and Fe based monometallic catalysts supported on sol gel derived $\mathrm{SiO}_{2}$ microflakes," Chemical Engineering Journal, 2015, 262,1009-1021.

[48] A. Awadallah, A. Aboul-Enein, D. El-Desouki, and A. Aboul-Gheit, "Catalytic thermal decomposition of methane to COx-free hydrogen and carbon nanotubes over $\mathrm{MgO}$ supported bimetallic group VIII catalysts," Applied Surface Science, 2014, 296, 100-10.

[49] M. Pudukudy, Z. Yaakob, and Z. S. Akmal, "Direct decomposition of methane over Pd promoted Ni/SBA-15 catalysts," Applied Surface Science, 2015, 353, 127-136.

[50] M. Pudukudy, Z. Yaakob, and M. S. Takriff, "Methane decomposition over Pd promoted $\mathrm{Ni} / \mathrm{MgAl} 2 \mathrm{O} 4$ catalysts for the production of $\mathrm{COx}$ free hydrogen and multiwalled carbon nanotubes," Applied Surface Science, 2015, 356, 1320-1326.

[51] A. Awadallah, A. Aboul-Enein, M. Yonis, and A. Aboul-Gheit, "Effect of structural promoters on the catalytic performance of cobalt-based catalysts during natural gas 
decomposition to hydrogen and carbon nanotubes," Fullerenes, Nanotubes and Carbon Nanostructures, 2016, 24, 181-18.

[52] R. R. Silva, H. A. Oliveira, A. C. Guarino, B. B. Toledo, M. B. Moura, B. T. Oliveira, et al., "Effect of support on methane decomposition for hydrogen production over cobalt catalysts," International Journal of Hydrogen Energy, 2016, 41,6763-6772.

[53] A. Al-Fatesh, A. Fakeeha, W. Khan, A. Ibrahim, S. He, and K. Seshan, "Production of hydrogen by catalytic methane decomposition over alumina supported mono-, bi-and trimetallic catalysts," International Journal of Hydrogen Energy, 2016. 41, 22932-22940.

[54] M. Pudukudy, A. Kadier, Z. Yaakob, and M. S. Takriff, "Non-oxidative thermocatalytic decomposition of methane into COx free hydrogen and nanocarbon over unsupported porous $\mathrm{NiO}$ and $\mathrm{Fe}_{2} \mathrm{O}_{3}$ catalysts," International Journal of Hydrogen Energy, 2016, 41,18509-18521.

[55] I. L. S. Mei, S. Lock, D.-V. N. Vo, and A. Bawadi, "Thermo-Catalytic Methane Decomposition for Hydrogen Production: Effect of Palladium Promoter on Ni-based Catalysts," Bulletin of Chemical Reaction Engineering \& Catalysis,2016. 11, 191-199.

[56] M. Pudukudy, Z. Yaakob, M. Z. Mazuki, M. S. Takriff, and S. S. Jahaya, "One-pot sol-gel synthesis of $\mathrm{MgO}$ nanoparticles supported nickel and iron catalysts for undiluted methane decomposition into COx free hydrogen and nanocarbon," Applied Catalysis B: Environmental, 2017, 218298-316.

[57] A. E. Awadallah, A. A. Aboul-Enein, M. A. Azab, and Y. K. Abdel-Monem, "Influence of Mo or $\mathrm{Cu}$ doping in $\mathrm{Fe} / \mathrm{MgO}$ catalyst for synthesis of single-walled carbon nanotubes by catalytic chemical vapor deposition of methane," Fullerenes, Nanotubes and Carbon Nanostructures, 2017, 25, 256-264. 
[58] C. Anjaneyulu, S. N. Kumar, V. V. Kumar, G. Naresh, S. Bhargava, K. Chary, et al., "Influence of $\mathrm{La}$ on reduction behaviour and $\mathrm{Ni}$ metal surface area of $\mathrm{Ni}-\mathrm{Al} 2 \mathrm{O} 3$ catalysts for $\mathrm{CO}$ x free $\mathrm{H} 2$ by catalytic decomposition of methane," international journal of hydrogen energy, 2015, 40,3633-364.

[59] A. Venugopal, S. N. Kumar, J. Ashok, D. H. Prasad, V. D. Kumari, K. Prasad, et al., "Hydrogen production by catalytic decomposition of methane over $\mathrm{Ni} / \mathrm{SiO}_{2}$, " International Journal of Hydrogen Energy, 2007 32, 1782-1788.

[60] Y. Echegoyen, I. Suelves, M. Lazaro, R. Moliner, and J. Palacios, "Hydrogen production by thermocatalytic decomposition of methane over $\mathrm{Ni}-\mathrm{Al}$ and $\mathrm{Ni}-\mathrm{Cu}-\mathrm{Al}$ catalysts: Effect of calcination temperature," Journal of Power Sources, 2007, 169, 150-157.

[61] Y. Echegoyen, I. Suelves, M. Lázaro, M. Sanjuán, and R. Moliner, "Thermo catalytic decomposition of methane over $\mathrm{Ni}-\mathrm{Mg}$ and $\mathrm{Ni}-\mathrm{Cu}-\mathrm{Mg}$ catalysts: effect of catalyst preparation method," Applied Catalysis A: General,2007, 333, 229-237.

[62] M. J. Lázaro, Y. Echegoyen, I. Suelves, J. M. Palacios, and R. Moliner, "Decomposition of methane over $\mathrm{Ni}_{-} \mathrm{SiO}_{2}$ and $\mathrm{Ni}-\mathrm{Cu}-\mathrm{SiO}_{2}$ catalysts: effect of catalyst preparation method," Applied Catalysis A: General,2007,329, 22-29.

[63] M. Lazaro, Y. Echegoyen, C. Alegre, I. Suelves, R. Moliner, and J. Palacios, "TiO 2 as textural promoter on high loaded Ni catalysts for methane decomposition," International Journal of hydrogen energy, 2008, 33, 3320-3329.

[64] A. E. Awadallah, F. K. Gad, A. A. Aboul-Enein, M. R. Labib, and A. K. Aboul-Gheit, "Direct conversion of natural gas into COx-free hydrogen and MWCNTs over commercial $\mathrm{Ni}-\mathrm{Mo} / \mathrm{Al}_{2} \mathrm{O}_{3}$ catalyst: Effect of reaction parameters," Egyptian Journal of Petroleum, 2013. 22, 27-34,. 
[65] A. E. Awadallah, A. A. Aboul-Enein, and A. K. Aboul-Gheit, "Various nickel doping in commercial $\mathrm{Ni}-\mathrm{Mo} / \mathrm{Al}_{2} \mathrm{O}_{3}$ as catalysts for natural gas decomposition to $\mathrm{COx}$-free hydrogen production," Renewable energy, 2013,57, 671-678.

[66] W. Ahmed, A. E. Awadallah, and A. A. Aboul-Enein, "Ni/CeO $\mathrm{Ce}_{2}-\mathrm{Al}_{2} \mathrm{O}_{3}$ catalysts for methane thermo-catalytic decomposition to $\mathrm{COx}$-free $\mathrm{H}_{2}$ production," International Journal of Hydrogen Energy, 2016, 41, 18484-18493.

[67] A.-S. Al-Fatesh, S. Barama, A.-A. Ibrahim, A. Barama, W.-U. Khan, and A. Fakeeha, "Study of Methane Decomposition on Fe/MgO-Based Catalyst Modified by $\mathrm{Ni}$, Co, and Mn Additives," Chemical Engineering Communications, 2017.1-11

[68] A. S. Al-Fatesh, A. Amin, A. A. Ibrahim, W. U. Khan, M. A. Soliman, R. L. AL-Otaibi, et al., "Effect of $\mathrm{Ce}$ and $\mathrm{Co}$ addition to $\mathrm{Fe} / \mathrm{Al} 2 \mathrm{O} 3$ for catalytic methane decomposition," Catalysts, 2016. 6, 40

[69] A. H. Fakeeha, W. U. Khan, A. S. Al-Fatesh, A. E. Abasaeed, and M. A. Naeem, "Production of hydrogen and carbon nanofibers from methane over Nie CoeAl catalysts," Int J Hydrogen Energy, 2015, 40,81.

[70] A. Al-Fatesh, A. Fakeeha, A. Ibrahim, W. Khan, H. Atia, R. Eckelt, et al., "Decomposition of methane over alumina supported $\mathrm{Fe}$ and $\mathrm{Ni}-\mathrm{Fe}$ bimetallic catalyst: Effect of preparation procedure and calcination temperature," Journal of Saudi Chemical Society, 2016, 22, 239247.

[71] W. U. Khan, A. H. Fakeeha, A. S. Al-Fatesh, A. A. Ibrahim, and A. E. Abasaeed, "La2 $\mathrm{O}_{3}$ supported bimetallic catalysts for the production of hydrogen and carbon nanomaterials from methane," International Journal of Hydrogen Energy, 2015, 41, 976-983 
[72] A. H. Fakeeha, W. U. Khan, A. S. Al-Fatesh, A. A. Ibrahim, and A. E. Abasaeed, "Production of hydrogen from methane over lanthanum supported bimetallic catalysts," International Journal of Hydrogen Energy,2016,41,8193-8198.

[73] N. Bayat, M. Rezaei, and F. Meshkani, "Methane dissociation to COx-free hydrogen and carbon nanofiber over Ni-Cu/Al 2 O 3 catalysts," Fuel, 2017,195, 88-96.

[74] J. Ashok, P. S. Reddy, G. Raju, M. Subrahmanyam, and A. Venugopal, "Catalytic decomposition of methane to hydrogen and carbon nanofibers over $\mathrm{Ni}-\mathrm{Cu}-\mathrm{SiO} 2$ catalysts," Energy \& Fuels, 2008, 23, 5-13.

[75] S. K. Saraswat and K. Pant, "Synthesis of hydrogen and carbon nanotubes over copper promoted $\mathrm{Ni} / \mathrm{SiO}_{2}$ catalyst by thermocatalytic decomposition of methane," Journal of Natural Gas Science and Engineering, 2013, 13, 52-59.

[76] N. Bayat, M. Rezaei, and F. Meshkani, "Hydrogen and carbon nanofibers synthesis by methane decomposition over $\mathrm{Ni}-\mathrm{Pd} / \mathrm{Al}_{2} \mathrm{O}_{3}$ catalyst," International Journal of Hydrogen Energy, 2016, 41,5494-5503.

[77] N. Bayat, M. Rezaei, and F. Meshkani, "Methane decomposition over $\mathrm{Ni}-\mathrm{Fe} / \mathrm{Al}_{2} \mathrm{O}_{3}$ catalysts for production of COx-free hydrogen and carbon nanofiber," International Journal of Hydrogen Energy, 2016, 41,1574-1584.

[78] S. Fangli, S. Meiqing, F. Yanan, W. Jun, and W. Duan, "Influence of supports on catalytic performance and carbon deposition of palladium catalyst for methane partial oxidation," Journal of Rare Earths, 2007, 25, 316-320.

[79] A. Rastegarpanah, F. Meshkani, and M. Rezaei, "COx-free hydrogen and carbon nanofibers production by thermocatalytic decomposition of methane over mesoporous 
MgO· $\mathrm{Al}_{2} \mathrm{O}_{3}$ nanopowder-supported nickel catalysts," Fuel Processing Technology, 2017. $167,250-262$.

[80] A. Rastegarpanah, F. Meshkani, and M. Rezaei, "Thermocatalytic decomposition of methane over mesoporous nanocrystalline promoted $\mathrm{Ni} / \mathrm{MgO} \cdot \mathrm{Al}_{2} \mathrm{O}_{3}$ catalysts," International Journal of Hydrogen Energy, 2017, 42, 16476-16488.

[81] N. Izadi, A. Rashidi, M. Borghei, R. Karimzadeh, and A. Tofigh, "Synthesis of carbon nanofibres over nanoporous $\mathrm{Ni}-\mathrm{MgO}$ catalyst: influence of the bimetallic $\mathrm{Ni}-(\mathrm{Cu}, \mathrm{Co}, \mathrm{Mo})$ MgO catalysts," Journal of Experimental Nanoscience,2012, 7, 160-173.

[82] J. Li, L. Zhao, J. He, L. Dong, L. Xiong, Y. Du, et al., "Methane decomposition over highloaded Ni-Cu-SiO 2 catalysts," Fusion Engineering and Design, 2016, 113, 279-287.

[83] K. Srilatha, D. Bhagawan, and V. Himabindu, "Thermo catalytic decomposition of methane over $\mathrm{Cu}-\mathrm{Al}_{2} \mathrm{O}_{3}$ and $5-20 \mathrm{wt} \% \mathrm{Ni}-\mathrm{Cu}-\mathrm{Al} 2 \mathrm{O} 3$ catalysts to produce hydrogen and carbon nanofibers," 2016.

[84] A. E. Awadallah, S. M. Solyman, A. A. Aboul-Enein, H. A. Ahmed, N. A. Aboul-Gheit, and S. A. Hassan, "Effect of combining $\mathrm{Al}, \mathrm{Mg}, \mathrm{Ce}$ or La oxides to extracted rice husk nanosilica on the catalytic performance of $\mathrm{NiO}$ during $\mathrm{COx}$-free hydrogen production via methane decomposition," International Journal of Hydrogen Energy, 2017, 42, 98589872.

[85] A. H. Fakeeha, A. S. Al-Fatesh, B. Chowdhury, A. A. Ibrahim, W. U. Khan, S. Hassan, et al., "Bi-metallic catalysts of mesoporous $\mathrm{Al}_{2} \mathrm{O}_{3}$ supported on $\mathrm{Fe}, \mathrm{Ni}$ and $\mathrm{Mn}$ for Methane decomposition: Effect of activation temperature," Chinese Journal of Chemical Engineering, 2018. 
[86] S. K. Saraswat, B. Sinha, K. Pant, and R. B. Gupta, "Kinetic Study and Modeling of Homogeneous Thermocatalytic Decomposition of Methane over a $\mathrm{Ni}-\mathrm{Cu}-\mathrm{Zn} / \mathrm{Al}_{2} \mathrm{O}_{3}$ Catalyst for the Production of Hydrogen and Bamboo-Shaped Carbon Nanotubes," Industrial \& Engineering Chemistry Research, 2016, 55, 11672-11680.

[87] A. C. Lua and H. Y. Wang, "Hydrogen production by catalytic decomposition of methane over Ni-Cu-Co alloy particles," Applied Catalysis B: Environmental, 2014, 156,84-93.

[88] S. K. Saraswat and K. Pant, "Ni-Cu-Zn/MCM-22 catalysts for simultaneous production of hydrogen and multiwall carbon nanotubes via thermo-catalytic decomposition of methane," international journal of hydrogen energy, 2011, 36, 13352-13360.

[89] S. K. Saraswat and K. Pant, "Synthesis of carbon nanotubes by thermo catalytic decomposition of methane over $\mathrm{Cu}$ and $\mathrm{Zn}$ promoted Ni/MCM-22 catalyst," Journal of Environmental Chemical Engineering, 2013 1, 746-754.

[90] N. Bayat, F. Meshkani, and M. Rezaei, "Thermocatalytic decomposition of methane to $\mathrm{COx}$-free hydrogen and carbon over $\mathrm{Ni}-\mathrm{Fe}-\mathrm{Cu} / \mathrm{Al}_{2} \mathrm{O}_{3}$ catalysts," International Journal of Hydrogen Energy, 2016, 41,13039-13049.

[91] V. V. Chesnokov and A. S. Chichkan, "Production of hydrogen by methane catalytic decomposition over $\mathrm{Ni}-\mathrm{Cu}-\mathrm{Fe} / \mathrm{Al}_{2} \mathrm{O}_{3}$ catalyst," international journal of hydrogen energy, 2009, 34, 2979-2985.

[92] M. Pudukudy, Z. Yaakob, and M. S. Takriff, "Methane decomposition over unsupported mesoporous nickel ferrites: effect of reaction temperature on the catalytic activity and properties of the produced nanocarbon," RSC Advances, 2016, 6, 68081-68091. 
[93] M. Ermakova, D. Y. Ermakov, G. Kuvshinov, and L. Plyasova, "New nickel catalysts for the formation of filamentous carbon in the reaction of methane decomposition," Journal of catalysis, 1999, 187,77-84.

[94] F. M. Berndt and O. W. Perez-Lopez, "Catalytic decomposition of methane over $\mathrm{Ni} / \mathrm{SiO}_{2}$ : influence of $\mathrm{Cu}$ addition," Reaction Kinetics, Mechanisms and Catalysis, 2017, 120,181193.

[95] A. Konieczny, K. Mondal, T. Wiltowski, and P. Dydo, "Catalyst development for thermocatalytic decomposition of methane to hydrogen," International Journal of Hydrogen Energy, 208, 33,264-272.

[96] M. N. Uddin, W. W. Daud, and H. F. Abbas, "Co-production of hydrogen and carbon nanofibers from methane decomposition over zeolite Y supported Ni catalysts," Energy Conversion and Management, 2015, 90, 218-229.

[97] H. F. Abbas and W. W. Daud, "Thermocatalytic decomposition of methane using palm shell based activated carbon: kinetic and deactivation studies," Fuel processing technology, 2009, 90, 1167-1174.

[98] H. F. Abbas and W. W. Daud, "Thermocatalytic decomposition of methane for hydrogen production using activated carbon catalyst: regeneration and characterization studies," international journal of hydrogen energy, 2009, 34,8034-8045.

[99] J. Pinilla, I. Suelves, R. Utrilla, M. Gálvez, M. Lázaro, and R. Moliner, "Hydrogen production by thermo-catalytic decomposition of methane: regeneration of active carbons using $\mathrm{CO}_{2}$," Journal of power sources, 2007, 169, 103-109. 
[100] A. Malaika and M. Kozłowski, "Hydrogen production by propylene-assisted decomposition of methane over activated carbon catalysts," international journal of hydrogen energy, 2010, 35,10302-10310.

[101] J. Pinilla, I. Suelves, M. Lázaro, and R. Moliner, "Influence on hydrogen production of the minor components of natural gas during its decomposition using carbonaceous catalysts," Journal of Power Sources, 2009192, 100-106.

[102] A. Malaika and M. Kozłowski, "Influence of ethylene on carbon-catalysed decomposition of methane," international journal of hydrogen energy, 2009, 34, 2600-2605.

[103] A. Malaika, B. Krzyżyńska, and M. Kozłowski, "Catalytic decomposition of methane in the presence of in situ obtained ethylene as a method of hydrogen production," International journal of hydrogen energy, 2010, 35, 7470-7475.

[104] P. Rechnia, A. Malaika, B. Krzyżyńska, and M. Kozłowski, "Decomposition of methane in the presence of ethanol over activated carbon catalyst," international journal of hydrogen energy, 2012, 37, 14178-14186.

[105] P. Rechnia, A. Malaika, L. Najder-Kozdrowska, and M. Kozłowski, "The effect of ethanol on carbon-catalysed decomposition of methane," international journal of hydrogen energy, 2012, 37, 7512-7520.

[106] N. Z. Muradov, " $\mathrm{CO}_{2}$-free production of hydrogen by catalytic pyrolysis of hydrocarbon fuel," Energy \& Fuels, 1998, 12, 41-4.

[107] A. Adamska, A. Malaika, and M. Kozłowski, "Carbon-catalyzed decomposition of methane in the presence of carbon dioxide," Energy \& Fuels, vol. 24, pp. 3307-3312, 2010. 
[108] B. Fidalgo, N. Muradov, and J. Menéndez, "Effect of $\mathrm{H}_{2} \mathrm{~S}$ on carbon-catalyzed methane decomposition and $\mathrm{CO}_{2}$ reforming reactions," international journal of hydrogen energy, 2012, 37, 14187-14194.

[109] N. Muradov, F. Smith, and T. Ali, "Catalytic activity of carbons for methane decomposition reaction," Catalysis Today, vol. 102, pp. 225-233, 2005.

[110] A. Erdőhelyi, K. Fodor, and T. Szailer, "Effect of $\mathrm{H}_{2} \mathrm{~S}$ on the reaction of methane with carbon dioxide over supported Rh catalysts," Applied Catalysis B: Environmental, 2004, 53153-16.

[111] G. Wang, H. Wang, Z. Tang, W. Li, and J. Bai, "Simultaneous production of hydrogen and multi-walled carbon nanotubes by ethanol decomposition over $\mathrm{Ni} / \mathrm{Al}_{2} \mathrm{O}_{3}$ catalysts," Applied Catalysis B: Environmental, 2009, 88142-15.

[112] A. Awad, N. Masiran, M. A. Salam, D.-V. N. Vo, and B. Abdullah, "Non-oxidative decomposition of methane/methanol mixture over mesoporous $\mathrm{Ni}-\mathrm{Cu} / \mathrm{Al}_{2} \mathrm{O}_{3}$ Co-doped catalysts," International Journal of Hydrogen Energy, 2018.

[113] M. H. Kim, E. K. Lee, J. H. Jun, S. J. Kong, G. Y. Han, B. K. Lee, et al., "Hydrogen production by catalytic decomposition of methane over activated carbons: kinetic study," International journal of hydrogen energy, 2004, 29, 187-193.

[114] J. Ashok, M. Subrahmanyam, and A. Venugopal, "Hydrotalcite structure derived Ni-CuAl catalysts for the production of $\mathrm{H}_{2}$ by $\mathrm{CH}_{4}$ decomposition," International Journal of Hydrogen Energy, 2008, 33, 2704-2713.

[115] J. Pinilla, I. Suelves, M. Lázaro, and R. Moliner, "Kinetic study of the thermal decomposition of methane using carbonaceous catalysts," Chemical Engineering Journal, 2008, 138, pp. 301-306. 
[116] U. Ashik, W. W. Daud, and H. F. Abbas, "Methane decomposition kinetics and reaction rate over $\mathrm{Ni} / \mathrm{SiO}_{2}$ nanocatalyst produced through co-precipitation cum modified Stöber method," International Journal of Hydrogen Energy, 2017, 42, 938-952,.

[117] H. Y. Wang and A. C. Lua, "Deactivation and kinetic studies of unsupported $\mathrm{Ni}$ and $\mathrm{Ni}-$ $\mathrm{Co}-\mathrm{Cu}$ alloy catalysts used for hydrogen production by methane decomposition," Chemical Engineering Journal, 2014, 243, 79-91,.

[118] H. L. Abbott and I. Harrison, "Methane dissociative chemisorption on Ru (0001) and comparison to metal nanocatalysts," Journal of Catalysis, 2008, 254, 27-38.

[119] M. Borghei, R. Karimzadeh, A. Rashidi, and N. Izadi, "Kinetics of methane decomposition to $\mathrm{COx}$-free hydrogen and carbon nanofiber over $\mathrm{Ni}-\mathrm{Cu} / \mathrm{MgO}$ catalyst," international journal of hydrogen energy, 2010, 35,9479-9488,.

[120] I. Kvande, D. Chen, Z. Yu, M. Rønning, and A. Holmen, "Optimization and scale-up of CNF production based on intrinsic kinetic data obtained from TEOM," Journal of Catalysis, 2008, 256,204-21.

[121] S. H. Sharif Zein, A. R. Mohamed, and P. S. Talpa Sai, "Kinetic studies on catalytic decomposition of methane to hydrogen and carbon over $\mathrm{Ni} / \mathrm{TiO}_{2}$ catalyst," Industrial \& engineering chemistry research, 2004, 43, 4864-487.

[122] S. Fukada, N. Nakamura, J. Monden, and M. Nishikawa, "Experimental study of cracking methane by $\mathrm{Ni} / \mathrm{SiO}_{2}$ catalyst," Journal of nuclear materials, vol. 329, pp. 1365-1369, 2004.

[123] T. V. Reshetenko, L. B. Avdeeva, Z. R. Ismagilov, A. L. Chuvilin, and V. A. Ushakov, "Carbon capacious $\mathrm{Ni}-\mathrm{Cu}-\mathrm{Al}_{2} \mathrm{O}_{3}$ catalysts for high-temperature methane decomposition," Applied Catalysis A: General, 2003: 247,51-63 